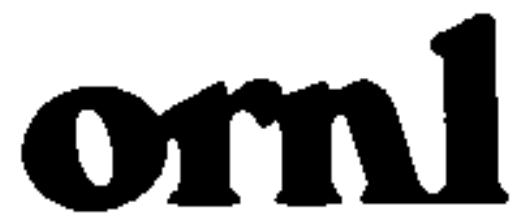

OAK RIDGE NATIONAL LABORATORY

MARTH MANHETRA

\section{MADAGED GY}

MAATLY MAAIETTA EUEAGY SYSTEUS, IIC. FOR THE UNITED STATES DEPAATWEET OF ENERGY
BECEVED

SEP. 09 49so

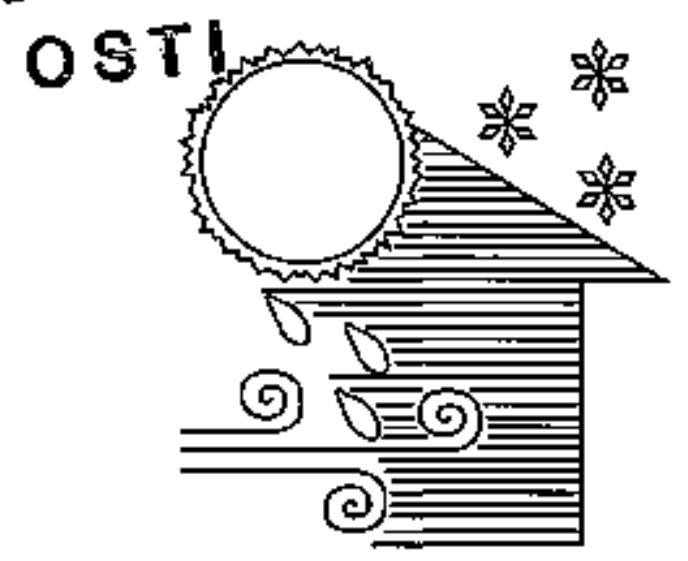

WEATHERIZATION WORKS:

Final Report of the National

Weatherization Evaluation

\author{
Marilyn A. Brown \\ Linda G. Berry \\ Laurence F. Kinney
}

\section{MASTER}

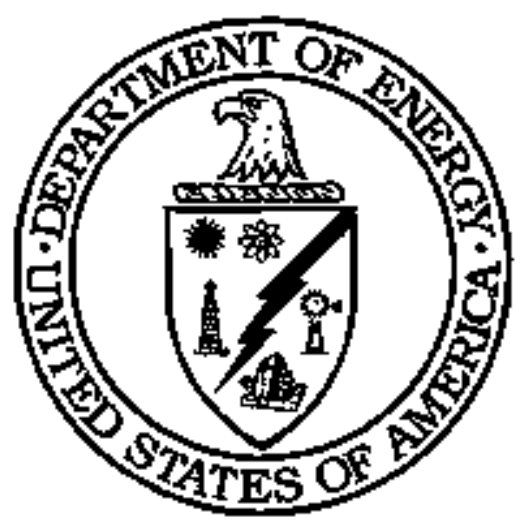

WEATHERIZATION ASSISTANCE PROGRAM

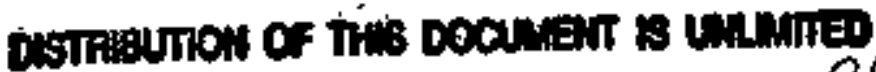


This report has been reprodued directly from the best avaluble copy.

Avelable to DOE and DOE comrectore trom the Office of Sclemific and Techrit cal hromation, P.O. Box 62, Oak Fidoe, TN a7a31; pricess avaliabis from (815) 57 Q68001, FIS 625-2401.

Avetiable to the pubio frown the Natianal Technical information Service, U.S. Depertment of Comrnerce, 5285 Port Royad Fid, \$pringiliat, VA 22161.

This report was prepered as an eccount of work aponeored by an ajency of the Unked Statos Govirmment. Neither the United Slates Government nor amy agency thereot, nor any of their employees, makes any waritanty, express or unptied, or ascumee any legel lablity or reeponebility for the accurecy. com.

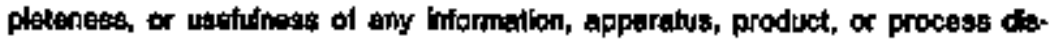
closed, or represents that tis use woutd not infinge privitety onntiod rigits. Reference hereit to eny specilic commercled profiluct, procees, or sentice by Irade namb, trademark, manufacturer, of othenwise, dowis not necessarily oanestitute or Imply ils endorsement, recommendaiton, or lavoring by the United Statos Covernment or any agoncy thereof. The viewg and oplnions of authora exprossagt hareln to not necessarily state or reflect those of the United Stetes Government or any edency thereor. 


\title{
WEATHERIZATION WORKS: Final Report of the National Weatherization Evaluation
}

\author{
Marilyn A. Brown \\ Linda G. Berry \\ Laurence F. Kinney* \\ * Synertech Systems Corporation
}

September 1994

Prepared for the

Weatherization Assistance Programs Division

U. S. Department of Energy

Prepared by the

Oak Ridge National Laboratory

Oak Ridge, Tennessee 37831

Managed by

Martin Marietta Energy Systems, Inc.

for the

U. S. Department of Energy

under Contract DE-AC05-840R21400 


\section{Weatherization Works: \\ An Interim Report of the National Weatherization Evaluation At a Glance}

NATIONAL SAMPLE OF SINGLE-FAMRLY AND SMALE MDLTLEAMUY HOMES

Nanber of Local Weatherization Agencies

Number of Weatherized Dwelings with Agency Data ${ }^{3}$

Number of Utilities Providing Data

Nuatber of Weatherized Dwellings with Utility Data
368 (of 400 in origintal sample)

14,971 (of 18,748 in original sampie)

543 (of 926 contacted)

4,796 (of 13,162 gas or electrictally heated dweltings)

\section{NORTFIEAST SAMPLE OF FUELOIL_HEATED HOMES}

Nuriber of Local Weatherization Agencies

Number of Weatherized Dwellings with Agency and Fuel-Use Data
42 (from 9 Northeastern \$lates where $70 \%$ of fixel-oil heated homes are located)

222 (sampled from population of about 23,000 bomes)

\section{BNERGY SAVINGS}

\section{Blrsturer Sarings:}

Gas $(50.6 \%$ of weatherized homes)

Electricity (9.5\% of weatherized homes)

Fuel oil (16.0\% of weatterized homes)

All fuels (100\% of weatherized homes)

Fingh Cas Sinvings

Cold climate region

Single-family detaclsed dwellings

10 exemplary agencies

Low Fas Soving

Hot climate region

Mobile bomes

20Lyear Sayings

All fuels

YAMIIR_OR BENETYTS

Gas Savings

Electricity Savings

Fuel-Oil Savings

Savings of All Fuels

Nैotenergy Bentefits

\section{COST-EFPECTIVENESS}

Program B/C Ratio ${ }^{c}$

Soctetal B/C Ratiod

\section{Gavines Per Druelling}

$17.3 \mathrm{MBt}$

$18.9 \mathrm{MBt}$

22.4 MBtu

17.6 MBu

23.5 MBtu

18.4 MEto

34.7 MBtw

$17.7 \%$

$14.1 \%$

$23.7 \%$

$\begin{array}{ll}13.0 \% & 18.3 \% \\ 12.2 \% & 35.9 \% \\ 17.7 \% & 17.7 \% \\ 13.5 \% & 18.2 \%\end{array}$

$9.1 \mathrm{MBtu}$

$10.9 \%$

$12.0 \%$

$15.4 \%$

12,0 MBEu

69.7 eriltion Btu's or the equivalent of 12 million berrels of oil
First yefr.

\$10 $/$ dwelling

$\$ 128 / d w a l l i n g$

$\$ 162 /$ dwellimg

sl16/dwelling

$\$ 816 / d w e l l i n g$

\section{Electritcally Feated}

1.13

1.06

1.61

2.33
Enel-OnL Heated

1.48

2.01
$24.9 \%$

19.9\%

33.4 뚱 


\section{DISCLAIMER}

Portions of this document may be illegible in electronic image products. Images are produced from the best available original document. 


\section{CONTENTS}

The National Weatherization Evaluation Is described in two ways in this summary document. The text on the right-hand (odd) pages summarizes the results of the evaluation conducted by the OakRidge Natlonal Laboratory. The photographs and explanations on the left-hand (even) pages illustrate weatherlzation operation and tactlcs.

\section{Even pages}

Remarks by Clinton and O'Leary

Single-Family Detached Homes

Mobile Homes

Row Homes

Large Mnltifamily Buildings .

Housing Rehabilitation

The Geography of Utility Funding

Profiles of Six Coordinated Programs

Ait Infiltration/Exfiltration

Advanced Air Sealing.

Blower Doors

Dense Pack Cel]ulose

Altics

Basernents

Heaith and Safety

Heating Systems

Distribution Systems

Domestic Hot Water

Doors and Windows

Mobile Homes Measures

Large Multifamily Measures

Advanced Energy Audits

High Savings from Attic Insulation

Targeting Savings Potential .

Targeting Needy Households

Putting It All Together

Keys to Success

Notes and References

Acknowledgments
Odd pages

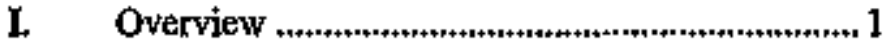

II. Program History ............+...+..................................... 3

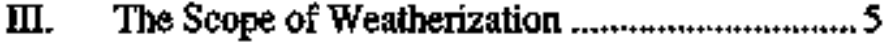

A. Types of Measures Used ................................5

Measures for Mobile Homes .........................7 7

Row House Measures .....................................9

Measures for Large Buildings ......................9

B. Sources of Funds ....................................... 13

C. Uses of Funds: DOE Sets the Pace ............ 15

D. Utility Partnerships ..................................... is

IV. The Evaluation Process ....................................... 19

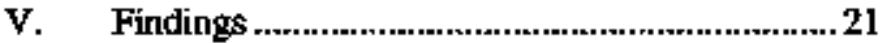

A. Diversity of Dwellings and Agencies ......... 21

The Typical Dwellings ...............................23

The Typical Agency ..................................23

B. Program Benefits .......................................25

National Energy Savings ............+........+.+...... 25

Nonenerigy Benefits ..................................27

C. Cost-Effectiveness ......................................33

Program Costs ..........................+....................... 33

National Cost-Effectiveness .......................35

D. Performance by Clinate Region ...................37

Cold Climate Region ............................... 37

Moderate Climate Region ..........................39

Hot Climate Region ....................................41

VI. Foundations for Change .................................. 43

A. Savings Associated With Specific

Program Practices ..............................+.............. 43

B. Promiting Management Practices ...............45

VII. Remaining Opportumities ...............................47

A. Additional Gnvestments Per Home ............... 47

B. Targeting Needy Households .......................51

VIII. The Future of Weatherization: Next Steps ........ 53

A. Service Delivery Procedures ........................ 53

B. Weatherization Measures ..............................55

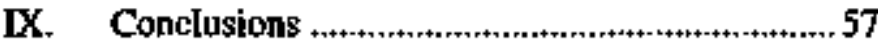

Appendix A .......................................... 6I-63 
'I have seen first hand how many jobs weatherization programs create and also how much good they can do ... A lot of this weatherization work for poor people, especially for a lot of elderly people who are stuck in these old houses that have holes in the walls ... or in the floor, not only makes them warmer in the winter and cooler in the summer, they also save money on their utility bilks. [Weathevization] conserves energy and puts more money in the pockets of people who have just bare]y enough to get by. So I strongly support [weatherization programs] . . . It's a kind of hard sell in the Congress now because the price of oil is so low and energy is so cheap-it's much cheaper in America than it is in any other major country. But if you just have enough to get by on, [if] you'ro living on a Socjal Security check or you"re living on a minimam wage, [utility bills] are still very, very expensive and a big part of your budget."

President Clinton's remarks concerning the Department of Energy's Weatherization Assistance Program at the Summer of Service Forum held at the University of Maryland, August 31, 1993.

"The Clinton administration is pledged to the weatherization program and its expansion as a preventive measure that works for America by helping poorfanilies save on fuel costs. This program also decreases reliance on oil imports, puts peopie to work on weatherization crews, and saves the environment by decreasing carbon emissions.... By any standard calculation, this progtam works."

Excerpf from Secretary O'Leary's statement at a press conference held in Boston, Massachusefts, on November 29, 1993. 


\section{Final Report of the National Weatherization Evaluation}

\section{OVERVIEW}

In 1990, the U.S. Department of Energy (DOE) sponsored a compreinensive evaluation of its Weatherization Assistance Program, the nation's largest residential energy conservation program. Oak Ridge National Laboratory (ORNL) managed the five-part study. This document summarizes the findings of the evaluation. Its conclusions are based mainty on data from the 1989 progxam year (supplemented by data from 1991-92).

The evaluation concludes that the Program meets the objectives of its enabling legislation and fulfills its mission statement. Specifically, it

- saves energy,

- lowers fuel bills, and

- improves the health and safety of dwellings occupied by

low-income people.

In addition, the Program achieves its mission in a cost-effective maner based on each of three perspectives employed by the evaluators. Finally, the evaluation estimates that the investments made in 1989 will, over a 20-year lifetime, save the equivalent of 12 million barrels of oil, roughly the amount of oil added to the Strategic Petroleum Reserve in each of the past several years.

The Program's mission is to reduce the heating and cooling costs for lowincome families-particularly the elderly, persons with disabitities, and children by inproving the energy efficiency of their homes and ensuring their health and safety. Substantial progress has been made, but the job is far from over. The Department of Health and Human Services (HHS) reports that the average low-income family spends 12 percent of its incorne on residential energy, compared to only 3 percent for the average-income family. Homes where low-income families live also have a greater need for energy efficiency improvements, but less money to pay for them.

In combination with closely related programs sponsored by the HHS and supplemental tunding from some states and electric and gas utility companjes, DOE's weatherization network of 1,100 local agencies has retrofitted more than four million dwellings since the inception of the program. According to the Energy Information Administration, 27.9 million dwellings are occupied by households with incomes below 150 percent of the poverty level. This does not mean that 14 percent of currently eligible housebolds (4 million of 27.9 million) have received weatherization services. The percentage is lower because households pass in and out of poverty and roughly one-nuarter of them move each year. Nevertheless, weatherization programs have improved a significant proportion of the housing that is likely to be occupied by low-and moderate-income households.

Notes and references are at the end of the text on pages 58-59. 


\section{SINGLE-FAMILY DETACHED HOMES}

This sevies of photographs illustrates the age and diversity of single-family homes weatherized by the Program. They are chosen from each of the three climate regions stodied under this evaluation.

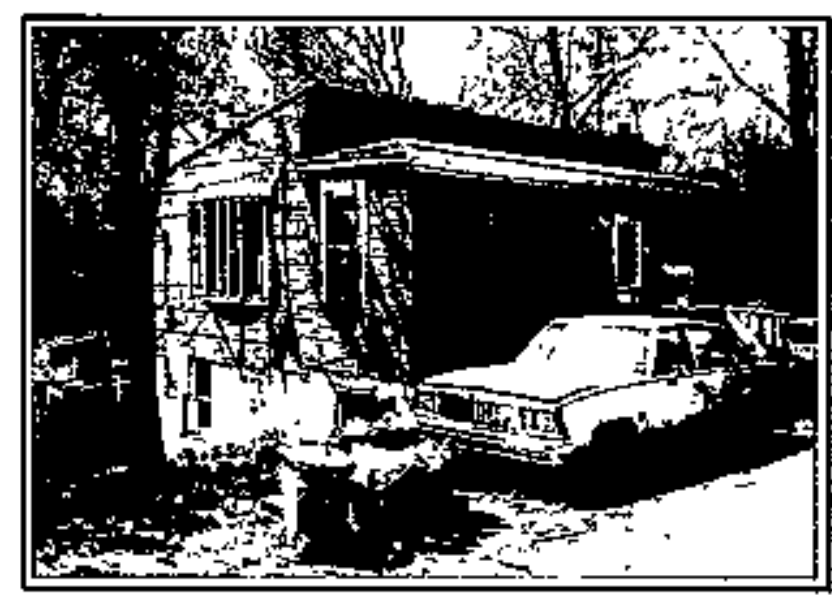

The weatherication job on this house will Include founda tion wall repair.

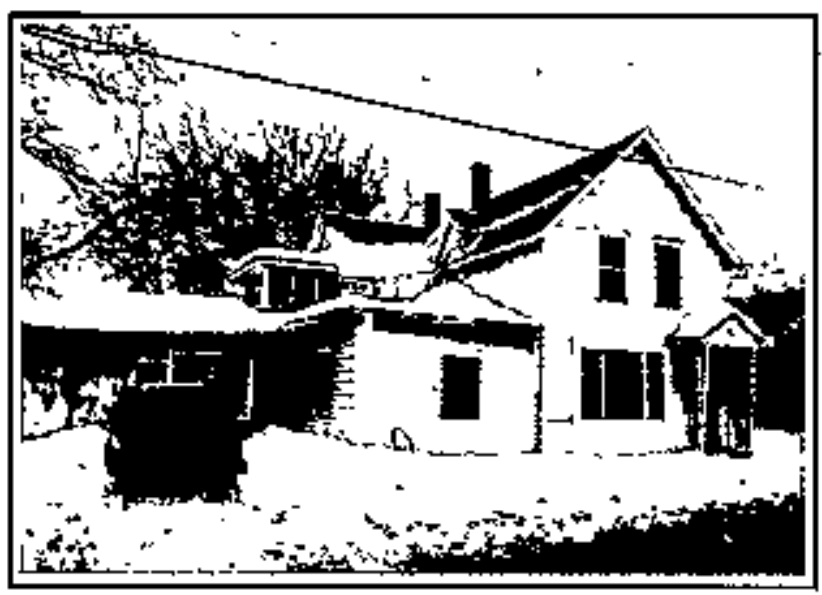

Paltems of snow and lce indlate a leaky, poorly insulated attlc.

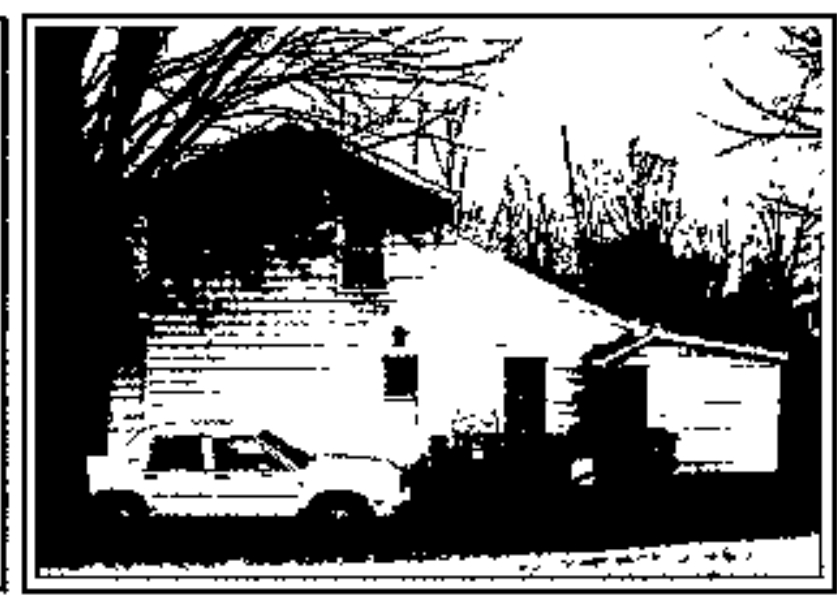

This rooline suaggests complex paths for ajr leakage.

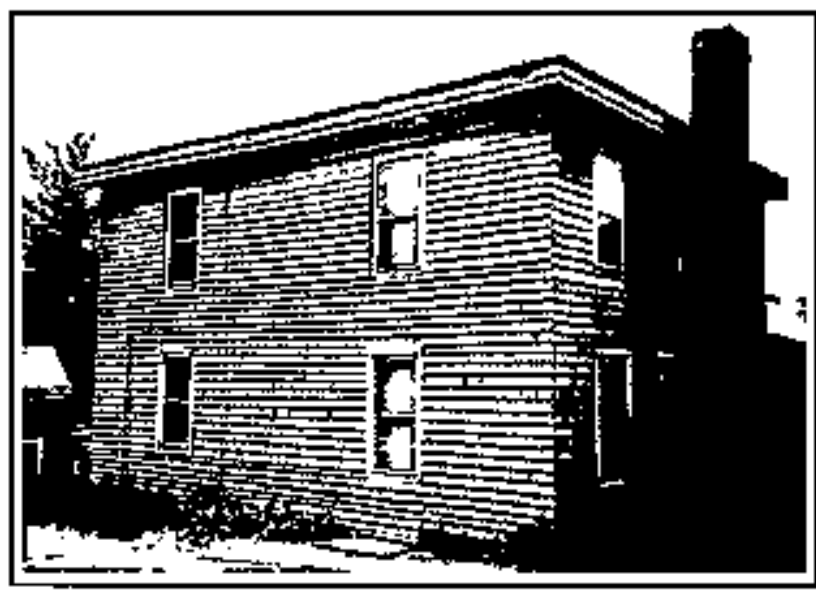

A gopd canctidate for wall insulation.

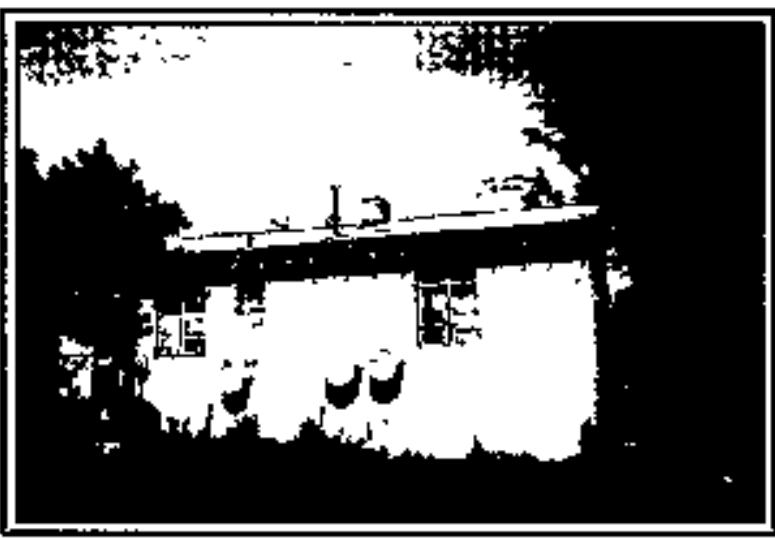

This cancrete block house is typical of hames that are weatherized in ruwal geoungta. 


\section{PROGRAM HISTORY}

The 1973 oil crisis hit Americans hard. Huge home heating bills hurt family budgets, sinking many into debt. The high heating bills hurt low-income families in colder states the most. In Maine, where nine out of ten homes are heated with oil, state officials and community action agencies worked with home owners and renters to seal house leaks where costly heated air poured out and cold air entered. Retrofiting cut bills and saved oil. Out of this effort, the nation's first weatherization program was bom. Congress created DOE's Weatherization Assistance Program in 1976 under Title IV of the Energy Conservation and Production Act.

In its early years, the Program emphasized emergency and temporary measures, including caulking and weatherstripping windows and doors, and low-cost measures such as covering windows with plastic sheets. By the

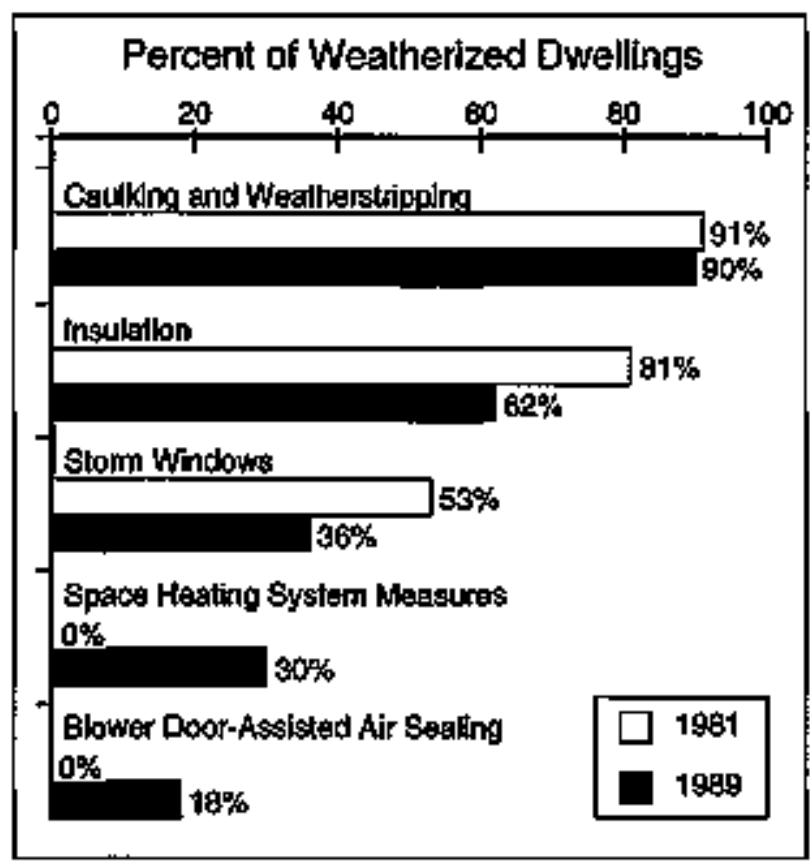

Installation Rates for Sekected Weatherlaation Measures in Single-Familly and Small Multifamily Homes, 1981 and 1989. early 1980 s, the emphasis had tumed to more permanent and more cost-effective measures such as installing storm windows and storm doors and attic insulation. In 1984, regutlations were passed to allow weatherization assistance funds to be spent on space and water heating system efficiency changes. In 1985, replacement of fumaces and boilers was approved.

Recent years have seen the increasing use of space heating system measures (such as tune-ups and installation of furnace component retrofits) and sophisticated diagnostic tools (such as blower doors). The staff has become more professional, and quality control has gone beyond visual inspections daring monitoring visits to include the use of sophisticated measurement procedures.

New regulations for 1993, which implement changes Congress authorized in 1990, encourage the use of health and safety enhancements and the most cost-effective techniques for saving energy. These new rules allow the use of cooling efficiency measures, includingairconditionerreplacement, ventilationequipment, and screening and shading devices. These measures will enable the Program to more effectively address the energy efficiency needs of hot climates. Barriers to performing work on heating systems and mechanical equipment also have been removed. The requirement that 40 percent of Progam funds be spent on materials is waived in states that adopt approved advanced audits, thus ensuring audit-driven cost-effective tests of investments. These and other changes allow the flexibility to select measures appropriate to particular regions and dwellings.

Funding for low-income weatherization has also changed. The most money was spent on weatherization in the 1980s. Funding levels have declined steadily since then. Despite funding changes, the Program has grown in scope and become more technically sophisticated. In 1989, 1,100 local agencies throughout the United States conducted weatherization operations using almost $\$ 500$ million from inultiple funding sources to weatherize approximately 250,000 low-income homes. 


\section{SINGLE-FAMIIX DETACHED HOMES}

\section{CONTINUED}

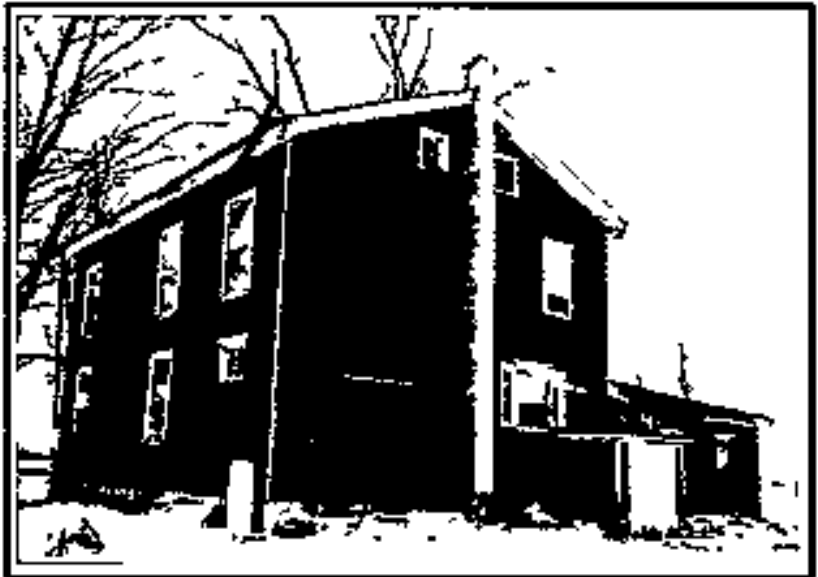

Thls tarmhouse saved over 50 percent by alr seallng, wall insulation, and funmace replacement.

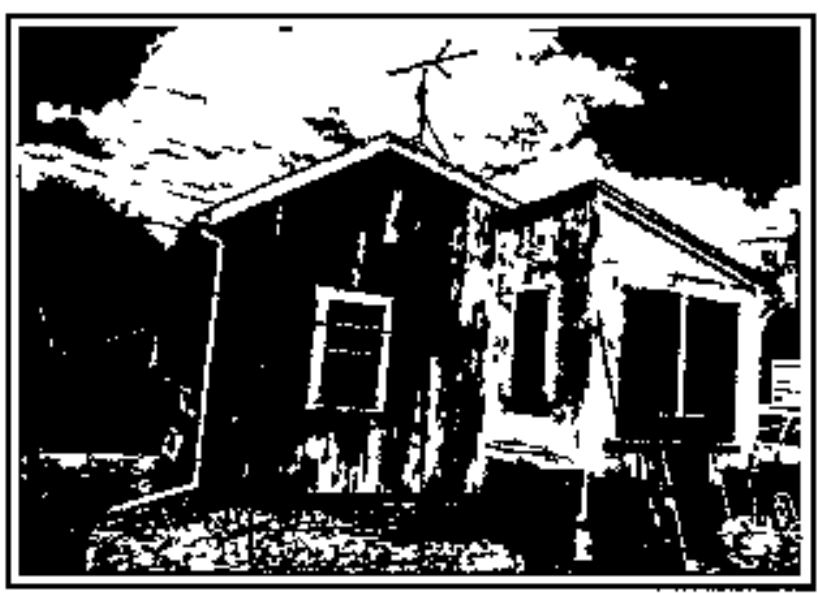

The intertace between old and neit is often a trouble spok.

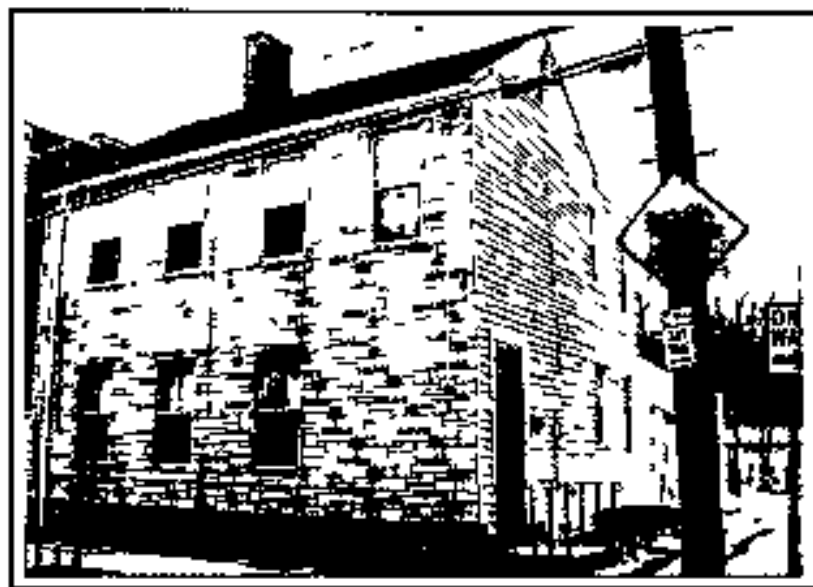

Fetroilt stifing hldes major holes that cause alr leakage.

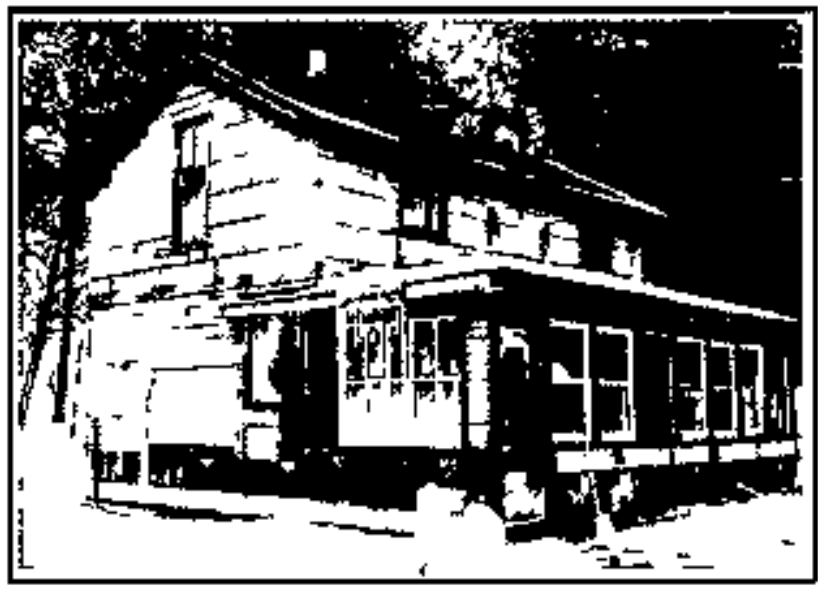

An unimsulated attic and air teakage between the porch and main struture ars the main entergy problams with this drrelling

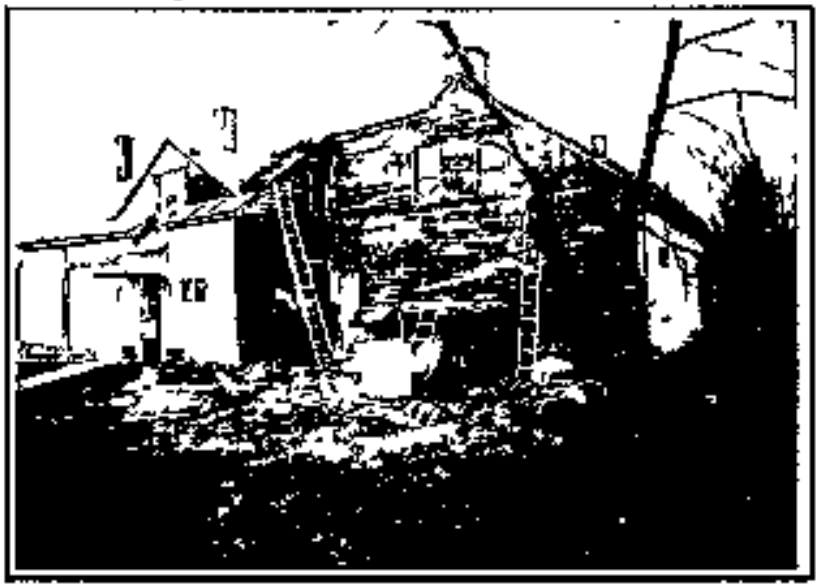

Movement of deleriorated foundation walls has opented large paltas for alr Ieakage.

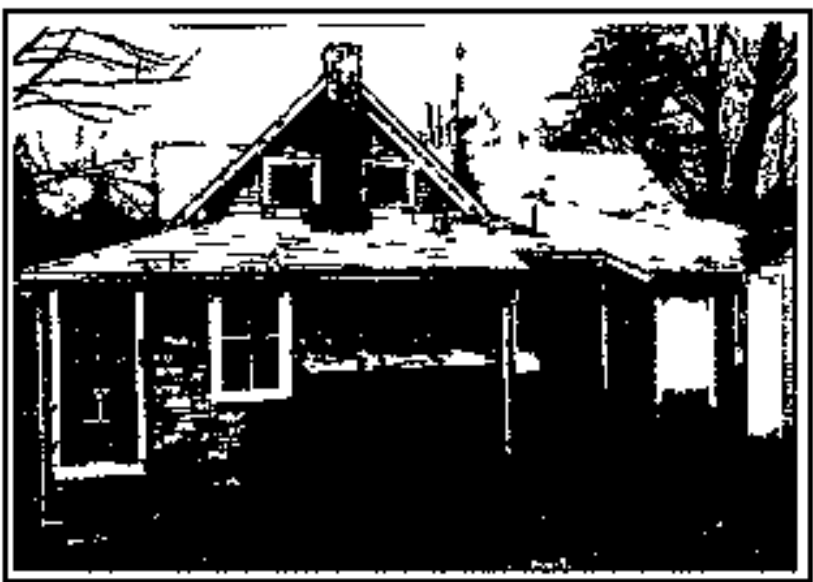

Built in sectlons over many years, this dweiting hat major leaks between the maln house and newer addifions. 


\section{THE SCOPE OF WEATHERIZATION}

\section{A. Types of Measures Used}

A variety of weatherization measures are used by DOE's Weatherization Program to improve the energy efficiency of dwellings occupied by lowincome people.

Air leakage control was the most common type of weatherization measure installed in single-family and snall multifanily dwellings in 1989. General caulking and weatherstripping around windows and dooss was by far the most common of these measures. However, air sealing with blower doors (18 percent) and without blower doors ( 23 percent), and air leakage control measures for distribution systems ( 7 percent) were also common.

Insulation was the next mast common type of energy conservation measure installed in 1989. Attic insulation was either installed for the first time or added to existing insulation in the majority of homes that received insulation. The measures of conventional wall insulation, rim or band joist insulation, and floor insulation were each added to between 10 and 20 percent of all weatherized homes. High-density wall insulation, foundation or perimeter insulation, altic or hatch access door insulation, and duct and crawlspace insulation were added to benween 1 and 2 percent of weatherized homes.

Energy-efficiency improvements to water heater systems were made in 56 percent of the weatherized homes. Most of these retrofits involved tank or pipe insulation. In addition, water temperatures were reduced and tow-flow showerheads were added to approximately 10 percent of homes.

Energy-efficiency improvements to windows and doors occurred in $\mathbf{4 2}$ percent of homes weatherized in 1989. Adtitional window and door work was conducted primarily forrepair purposes. By far, the majority of these improvements involved the addition of storm windows (36 percent) or the replacement of entire windows ( 37 percent). Altogether, storm windows were added or entire windows were replaced on 61 percent of the weatherized homes. Storm doors were added to 4 percent of the weatherized homes, and exterior doors were replaced on 38 percent of weatherized homes.

Nearly one-third ( 30 percent) of the homes weatherized in 1989 had energy-efficiency improvements made to their space heating systems. Most of these improvements involved tune-ups, during which the beating systems were cleaned, controls adjusted, and filters replaced. Heating system component retrofits were completed in 7 percent of the weatherized homes. Entire heating systems were replaced in approximately 4 percent of homes.

Different types of measures are considered when weatherizing large multifamily buildings. These include heating, ventilating, and airconditioning control systems and various ventilation system modifications. 
MOBIL HOMES

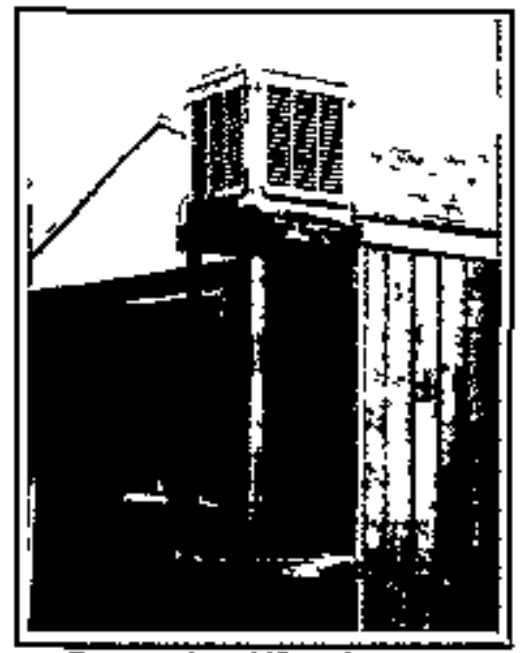

Evaparalive chifers (swamp coolers) often mean large leaks.

Dne to the economic reatitites of affordable housing, many low-income families live in mobile homes. Weatherizing mobile homes in the hot climate zone constitutes at least a quarter of all work in many agencies.

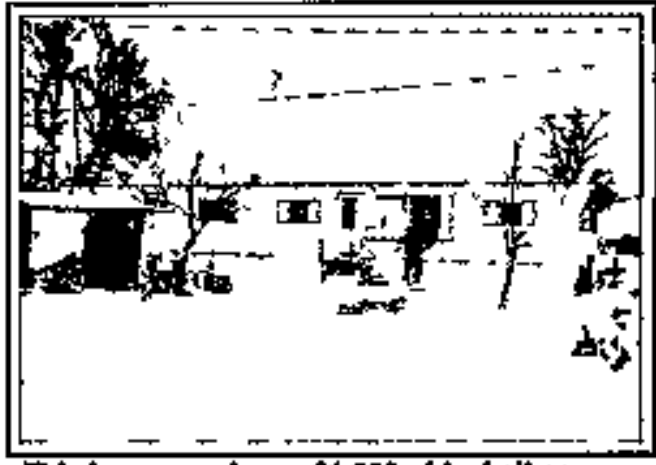

Thts home used over \$1,000 of fuel oll por heating season before weatheskatlon tightened it up and tingtalled a more ofiltient of burner.

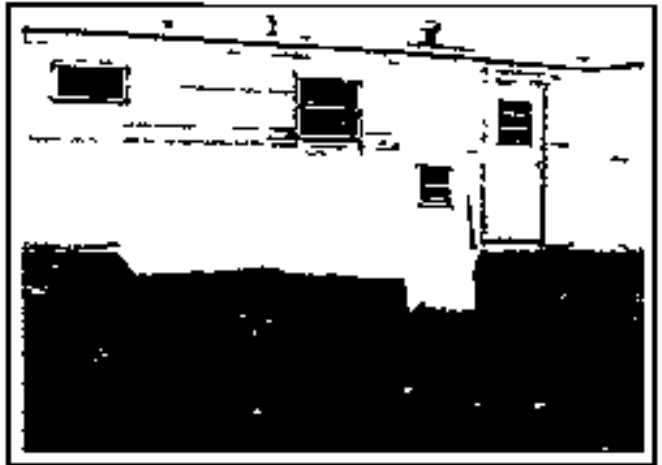

New doors and windows sombtimes save entirgy, but air seating ducts in moblle homes are usually a mora costeffective retrofil.

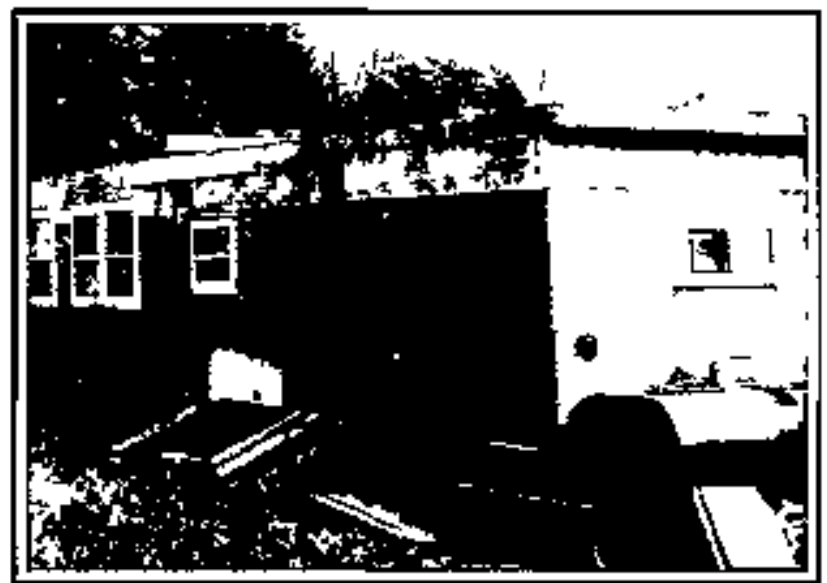

Very poor insulation causes major problems with moblle homes bulll before HID's anorgy standards wore adopted in 1976,

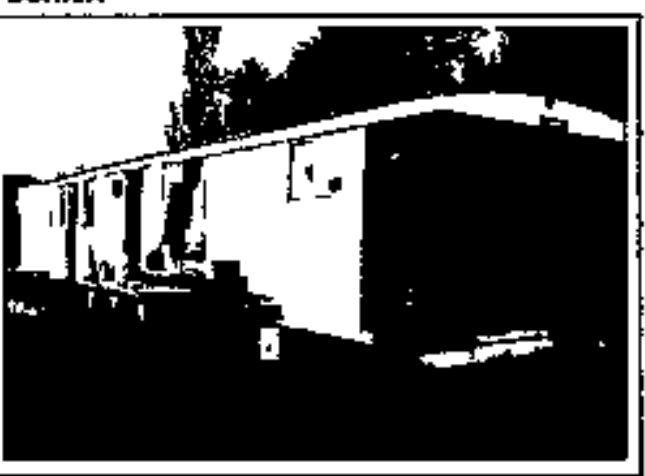

Loblle homes wilh poor foundations often dovelop major structiural problems.

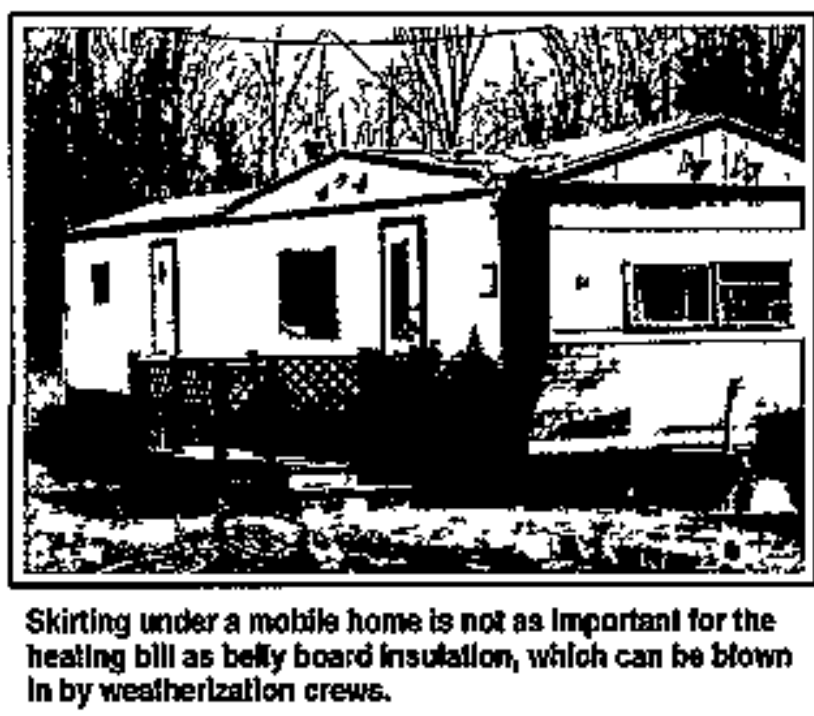




\section{Measures for Mobile Homes}

There are seven mitlion "manufactured homes" in the U.S. and the number is growing. Well over half were constructed before 1976 , when HUD initiated its mandatory national standards on manufactured home construction. These older units, which tend to be occupied by lower-iscome people, suffer from a variety of ills. Energy problems stem from shoddy construction, improper site set ups, and poor maintenance. As a result, many are leaky, unconfortable, and have high energy bills.

The profile of weatherization measures installed in mobile homes differs from that of ther housing types. In 1989, mobite homes were much less likely to receive any type of insulation than the average home (20\% vs. 62\%), and nearly all mobile home insulation consisted of floor insulation. Blowing the space between the belly board and the floor of older mobile tromes with insulation, in combination with attention to air sealing and duct leakage, solves many conductive and convective problems and raises the efficiency of the heating unit as well.

Blower door-assisted air sealing is becoming a more prominent part of mobile home weatherization. Quite frequently, major leaks are found in unobvious places, such as main electricial boxes, plumbing chases, and ducts. The combination of leaks in mobile home ducts and belly boards results not only in low heating and cooling system efficiency, but in uncontrolled air leakage. This wastes energy and can affect indoor air cuality, raise moisture levels, and cause structural deterioration.

In 1989, water heating measures were installed less frequently (48\% vs, $56 \%$ ) in mobile homes than in other types of structures, while window and door

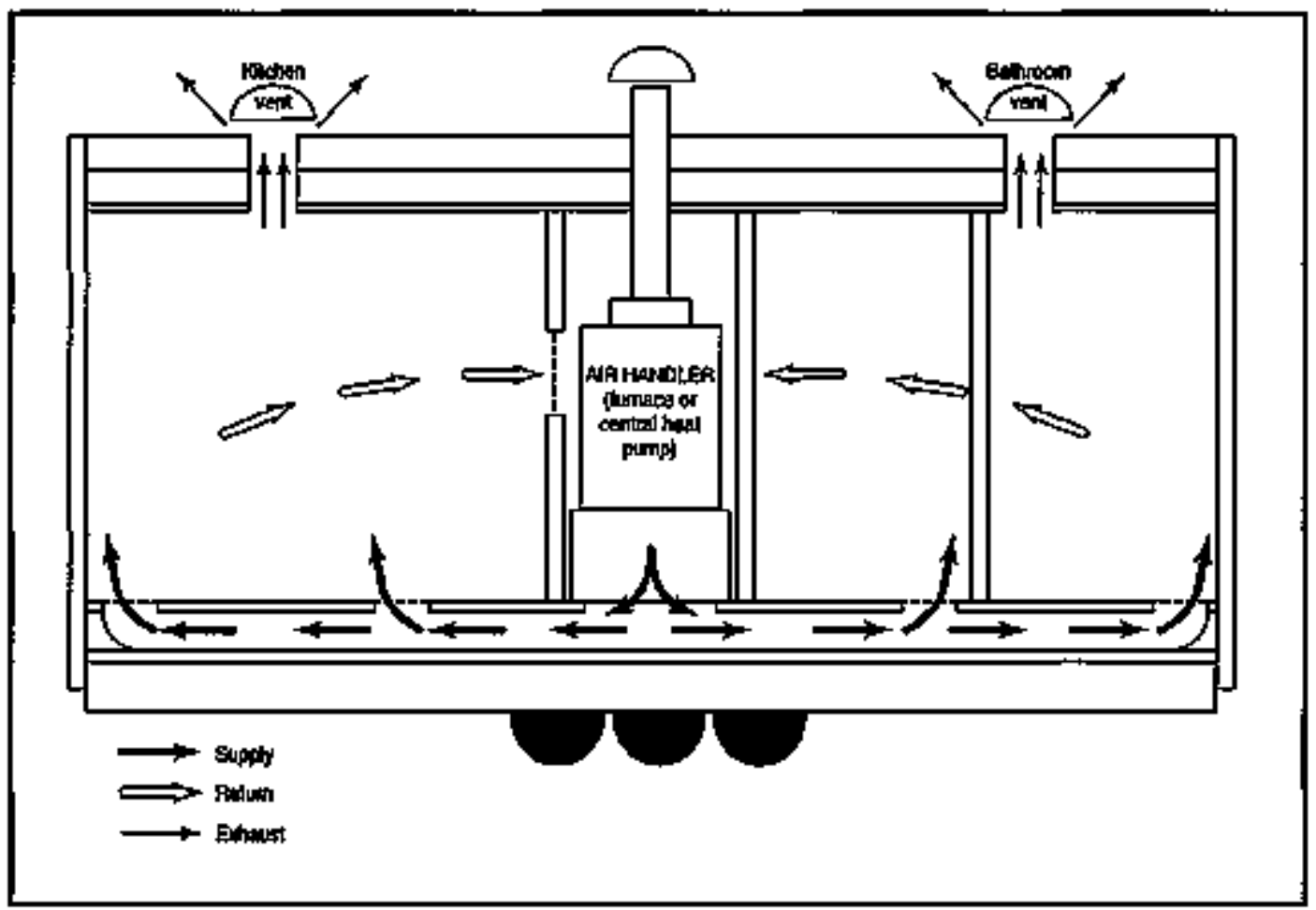
measures ( $50 \%$ vs. $42 \%$ ) were installed nore frequently. Installation of irside storm windows covering leaky jalousietype windows is especially common in mobile homes. Most mobile homes receive one or more measures that are especially suitable for this type of dwelling, includ. ing underpinning, skirting, cool seals on theroof, and belly boardinsulation. 
Alhough almost two-thirds of the dwellings weatherized in the year of the study are singlefamily detached structures, otherdwelting types are also common.

\section{ROW HOMES (SINGLE-FAMILY ATTACHED DWELLINGS)}

Row homes, which predominate in many older American cities in the Northeast, can be extremely wasteful of energy. Leaky flat roofs cause falling ceilings and massive air leakage.

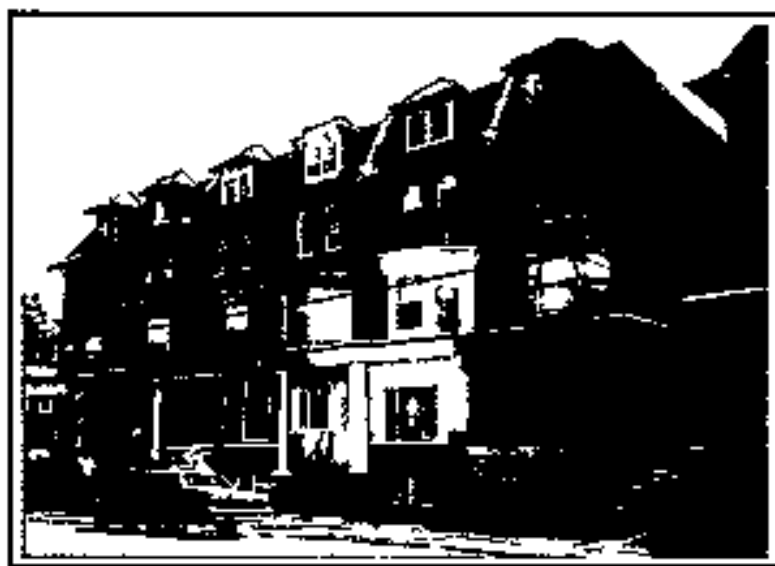

The space above porch ceilings is often connected to the Inside of the front weil.

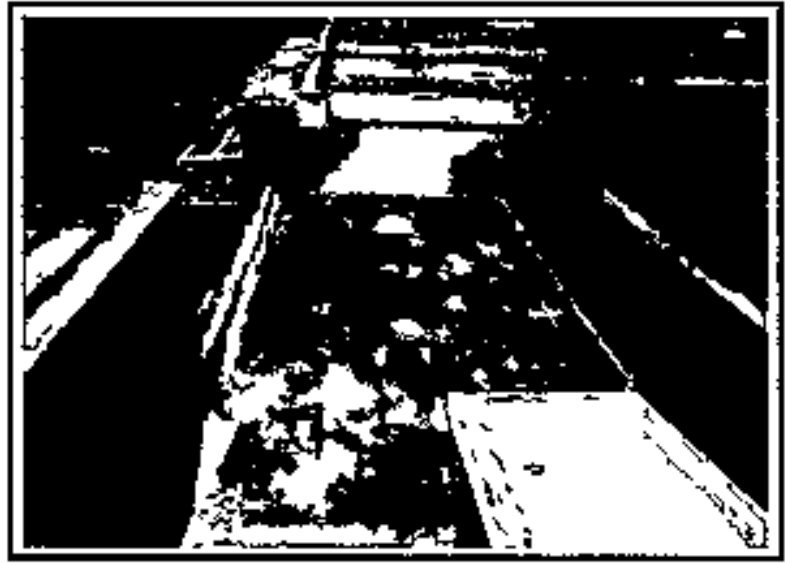

Leaky roofs posit bix problems.

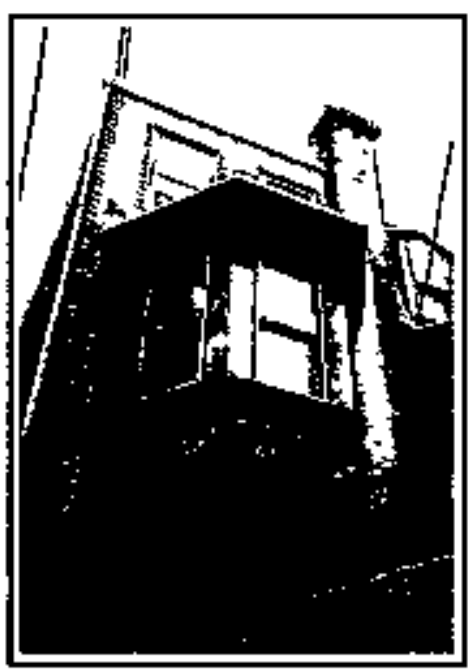

The space under Ihase bay wlindows may cause more energy waste than the windows thernsolvos.

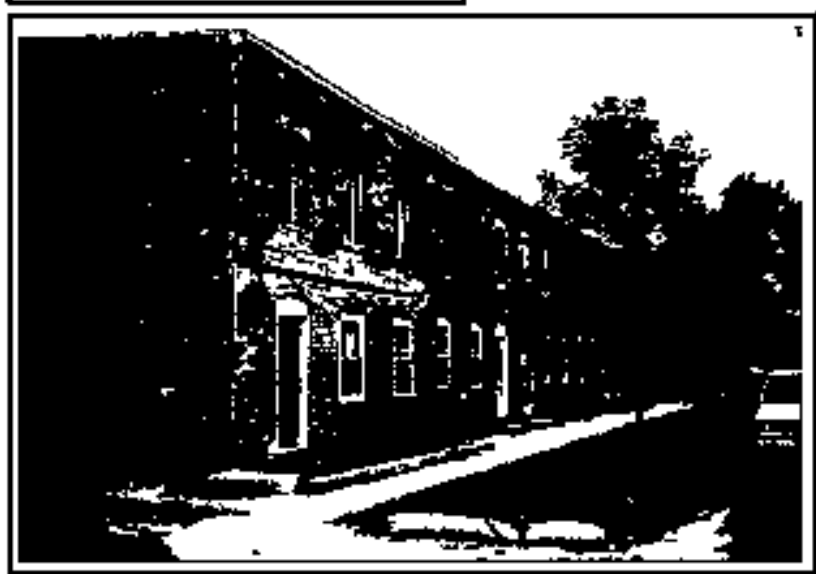

A solid exterlor may conceal inner decay.

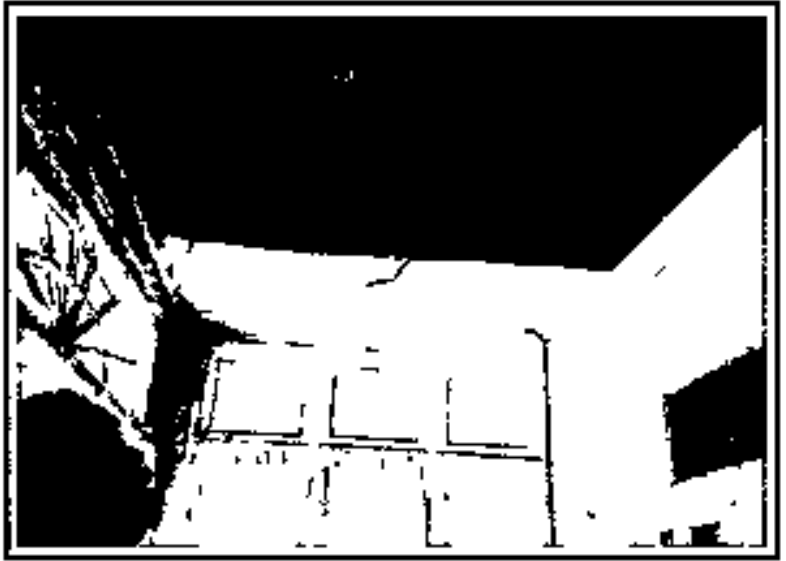

The consequances of unrapairad toof toeks.

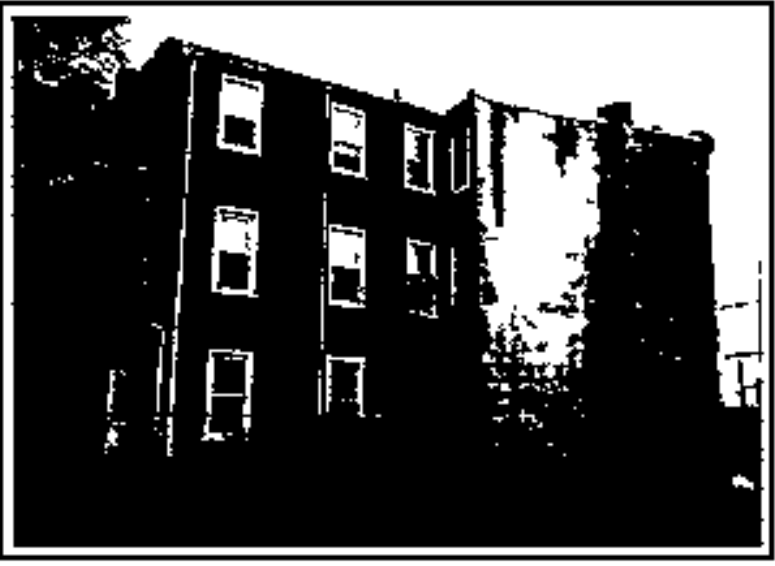




\section{Row House Measures}

Row honses tend to be among the most wasteful and leaky housing stock in the country. Accordingly, extensive air sealing measures are undertaken on vitually all weatherization jobs. The work is complicated by the fact that some air leakage may beconditioned air from an adjoining house, a fact that impacts bothenergy and indoor air quality. In addition, part of the inherent architectural charm of row houses, including such details as porches and bay windows, can mask subtle convective and conductive problents. Thus, air sealing row homes requires special care and sealing techniques.

"First time" attic insulation is installed at higher rates in Jow houses than in any oftser type of housing, an indication of the poor thermal condition of much of this housing stock. In addition, roof repairs are more frequently a part of the weatherization job for row bomes than for other housing types. A majot source of energy waste in older row homes occurs when their flat roofs leak water, uitimately causing ceilings to fall. This allows stack-effect infiltration to have devastating effects on the fuel bill. As explained on page 18, stackeffect infiltration results from the rising of warm air in the interior, palling in air at the bottom of the conditioned envelope and exhausting warm air at the top. Pressure differences at the top and bottom are at their maximaln, which makes holes in these areas critical to repair.

\section{Measures for Large Buildings}

The weatherization of large multifamily buildings, those with five or more units, presents local agencies with challenges different from those presented by smaller dwellings. Most of the work is accomplished in distressed utban areas where both buildings and mach of the surrounding communities suffer from maintenance problems and even abasdonment. Consequently, facade facelifts in the form of window repair and replacement has been the focal point of most large multifamily operations, accounting for 80 percent of material expenditures in Program Year 1989 in which 20,000 units in multifamily buitdings were weatherized (MacDonald, 1994).

The diversity of housing stock and approaches to weatherization found in the Single-Family Study tolds troe in themultifarmily sector, where the unique features of the urban environment require especially creative responses. This diversity is illustrated by findings from three case studies summarized below (Kinney, et al. 1994).

The New York City weatherization operation, with its 22 local agencies, accornplishes over half of themultifamily weatherization work done nationally by the Weatherization Program. The need is apparent New York City has 126,000 multifamily buildings with more tran 1.9 million apartuments. An average apartment uses over 865 gallons of fuel oil (or its equivalent) annually for heat and domestic hot water, a startlingly large number for the climate and average apartment size. This inefficiency makes multifamily buildings very good targets for cost-effective conservation retrofits. 


\section{LARGE MULTIFAMILY BUILDINGS}
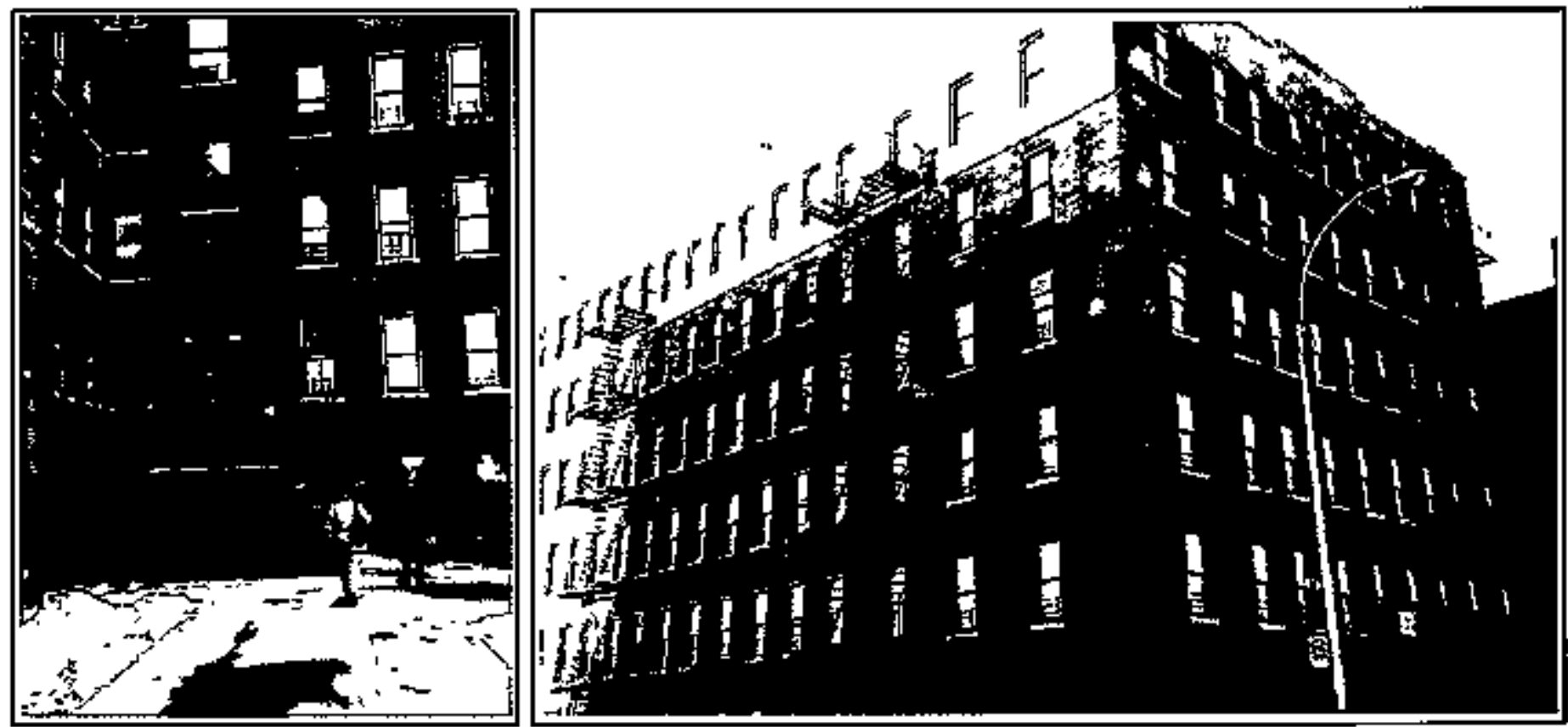

This large building in the Btonx was almost ready for abandonment when weatherlzeilon played a koy rote in lts nestoration.
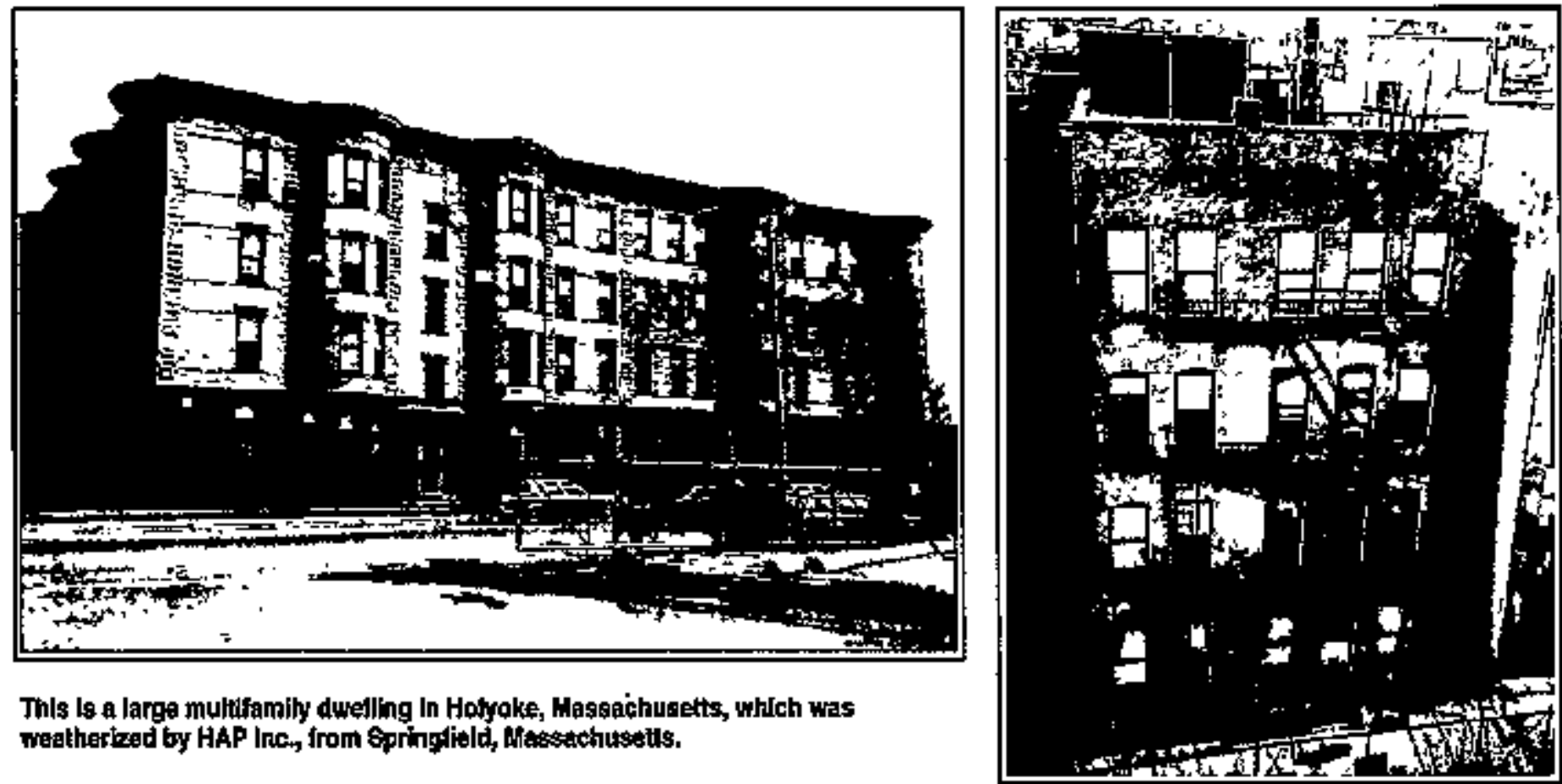

Thls ls a large multifamily dwelling In Hotyoke, Massachusetts, which was weatherized by HAP Inc., from Springtield, Mis tecthusetls.

Thits is the back of a tour-story building in Brookdyn. After alr sealing, boilor, and window replacemente, the energy expendlbures lor this butiding are epproxitnately 40 porcent less than the previous year's fuel expenditures. 


\section{Measures for Large Buildings (cont.)}

The trend in current multifamily weatherization operations in New York City is to concentrate on the heart of the building, the boiler room, and on its arteries, the distribution system. Poorly designed, controlled, and maintained heating systems are a major culprit in causing some buildings to consume five to six times as much energy as their neighbors. In response, professional energy auditors using state-of-the-art testing equiprnent and EA-QUIP analytical software, undertake building audits that result in detailed wokk orders. These include computations of costs and benefits of all retrofit measures anticipated and specifications of each element of the proposed work. These work orders, most of which are accomplished by the staff of the New York City Weatherization Coalition, are instrumental both in ensuring that resulting weatherization work meets rigorous standards and in leveraging funding from building owners.

In Chicago, the City goverument administers the Weatherization Program, serving single-family, smaller privately-owned multifamily buildings (typically three and four story walk-ups), and larger public housing projects managed by the Chicago Housing Authority. Working on the reputation of past performance, word of mouth results in a waiting list of over one year with buildings being served on a first-come, first-served basis.

In the past, weatherization measures were concentrated at the apariment level, and there was strong emphasis on storm windows and replacement windows. The new policy in Chicago is to weatherize whole buildings, which allows for working on heating systems before treating thermal losses in apartments. Frequently, the new policy results in the replacement of large, irefficient boilers and integrating modem electronic controls. In all cases, whenever major measures such as boiler replacements or large-scale window replacements are undertaken, building owners are required to bear 50 percent of the costs. In smaller buildings where tenants can control their own heat, digital thermostats are a frequently-installed measure.

Weatterization agencies in Minnesota weatherize about 1,000 large multifamily units each year, mostof which are in the Minneapolis-St. Paul area. These range from row houses to 20 -story high-rise brildings, but the most common are two- and three-story frame walk-ups with brick facades. Larger building work concentrates on boiler repair, controls, and distribution systems, with little emphasis on window repair work or even air sealing. Smaller buildings are air sealed (with emphisis on attic bypasses) and insulated like single-family dwellings. Multifanily work is guided by infonmation from fuel bills and instrumented audits.

Weatherization of large buildings in our Nation's largest cities is a complex process. Many people have to work together in order for good weatherization jobs-those that save and keep saving energy-to happen. There is a growing cadre of technically competent engineers and contractors who are involved in the Weatherization Progran's large multifamily retrofits. They practice such important crafts as making single-pipe stearn systens work efficiently. When their practical wisdom is communicated clearly to building supervisors, systems tend to be maintained much better, with the consequence that savings endure. Thìs can play a key role in the revitalization of distressed neighborhoods in our Nation's larger cities. 


\section{Housing Rehabilitation}

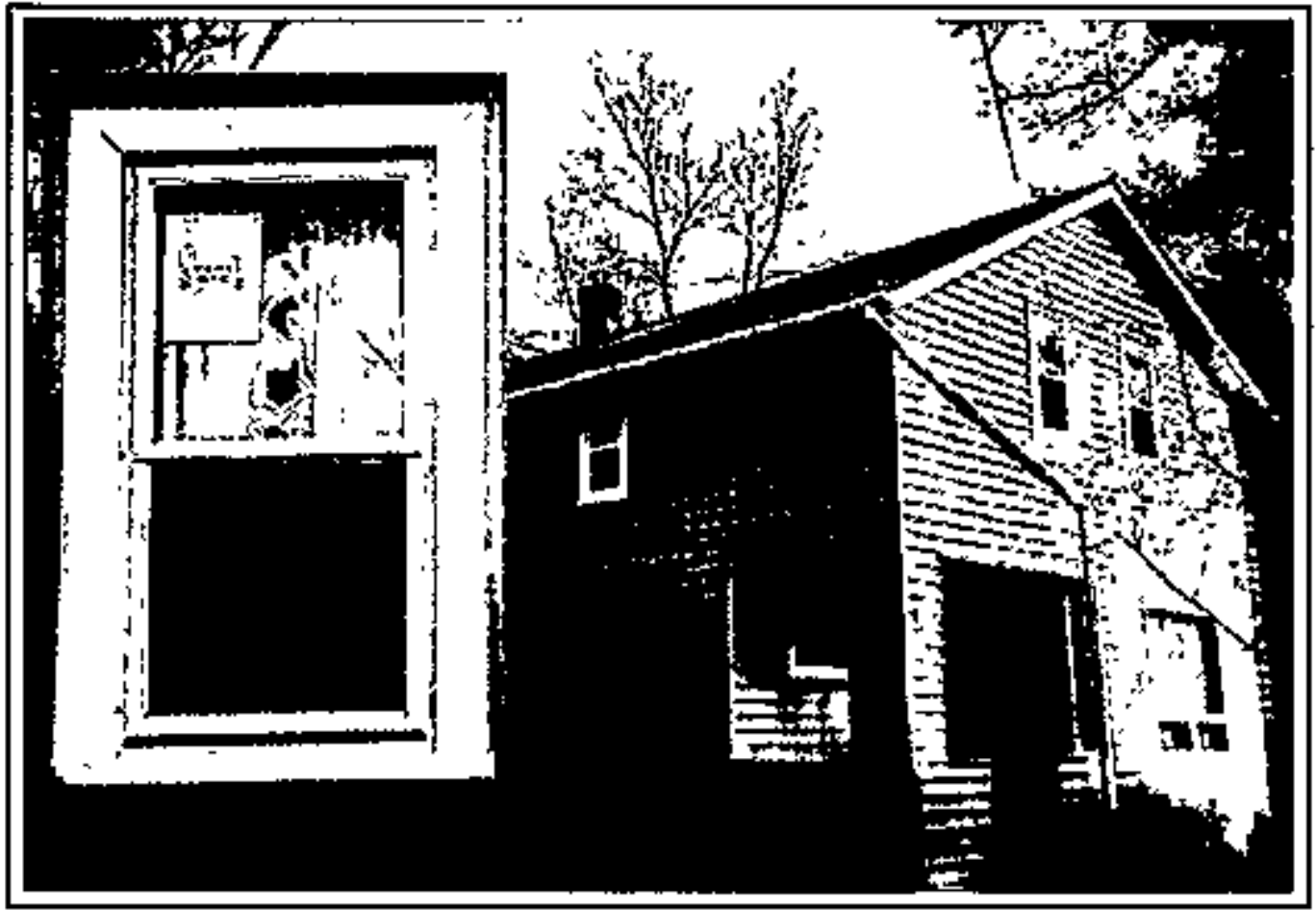

This rehablliteated home had new windows installed with HUD funds, and Insulatlon Installed with DOE funds.

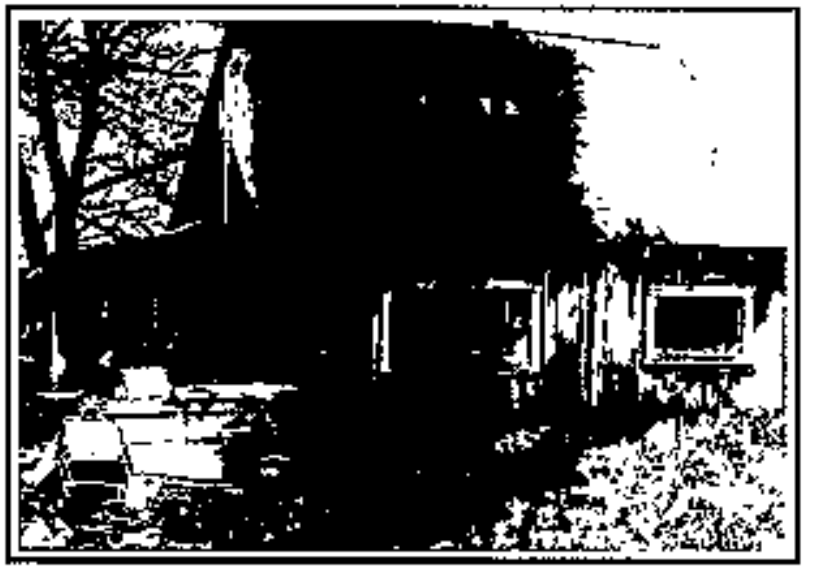

Before Weaktherization

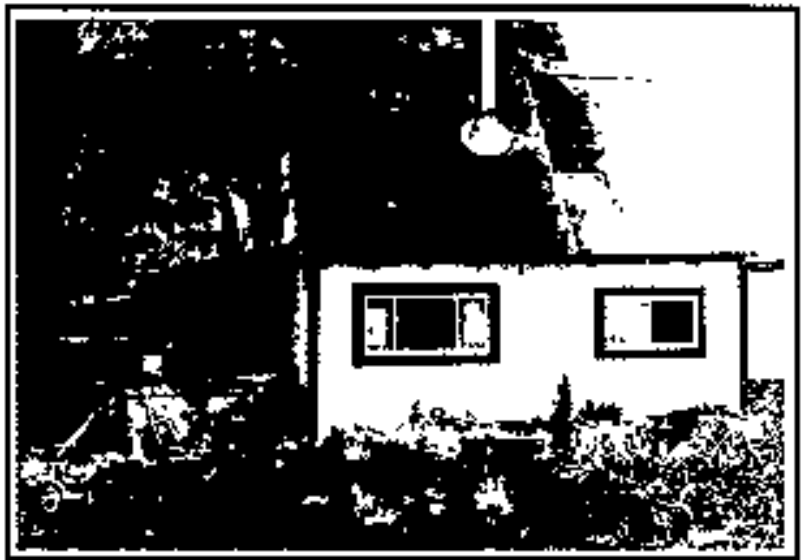

After Wealheriagition
This dilapidated home which received an impressive retrofit is one example of the substandard housing focal agencies often serve. Holes in roofs, walls, and ceilings, and broken wirdows are common problems. Leveraged funds from non-DOE sources are often used to meet housing rehabilitation needs. 


\section{B. Sources of Funds}

To implement the Program, DOE provides money to State Weatherization Agencies, more than 80 percent of which are located within executive departments responsible for human services, community development, or economic development. In turn, these agencies allocate funds to local agencies, of which 81 percent are private, nonprofit Commmity Action Agencies. Most of the rest are Iocal or county governmental agencies and Native American tribes. The weatherization work is done by employees of these local agencies or by contractors.

Although other organizations fund and implement low-income weatherization programs, DOE has been the dominant source of funding for low-income weatherization, providing 45 percent of total funding between 1978 and 1989 and a comparable level in recent years. There was more investment in low-income weatherization in the late 1980 s than in earlier years, but public funding levels have tapered off since then. More homes have been weatherized in cold states than in hot states, which partly reflects the formula used to allocate DOE's funds. The formula weights heating degree days more heavily

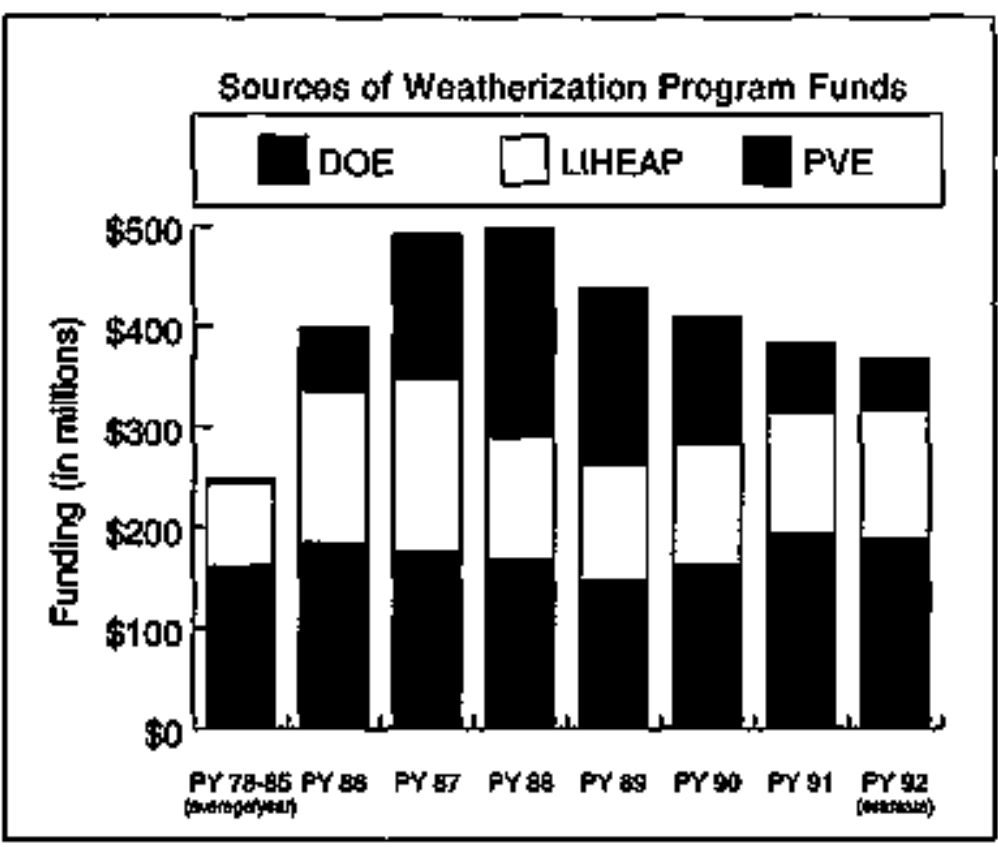

Three Major Sources of Weatherizatlog Progrann Funds, 1978 to 1992 than cooling degree days. On a national level, funding for all low-income weatherization activities in 1989 totaled $\$ 477.5$ milition, of which the largest single component was DOE funds of $\$ 149.7$ million (31 percent).

Asother majorsource of weatherization resources is the Low-Income Home Energy Assistance Program (LIHEAP), administered by HHS. Since 1982, states have had the flexibility to allocate up to 15 percent of LlHEAP funds (now 25 percent after receiving a waiver) to energy conservation measures. LIHEAP fanding peaked in 1987 and has since declined.

A third major source of weatherization money is the Petroleum Violation Escrow (PVE) Fund.These funds come from legal penalties assessed against oil companies convicted of violating price controls. The exhaustion of, PVE funds devoted to low-income weatherization on a one-time basis is the most dramatic cause of the decline in total weatherization funding from 1987 to 1992 . State program managers indicate that total funding for low-income weatherization has dipped 30 to 40 percent since 1990 , primarily because of the exhaustion of PVE funds.

Utilities provided 9.6 percent of funding available for low-income weatherization between 1978 and 1989; utility programs and funding were responsible for 22 percent of all units weatherized. During the 12 yearperiod, 49 utilities spent $\$ 418$ million on energy measures but invested only about one-third as much per unit as the DOE Weatherization Program. A small amount of funding for lowincorne weatherization comes frorn miscellaneons other sources, including owners of rental housing weatherized under the Program and state weatherization programs, which in some cases emphasized comprehensive home repair or heating system retrofits. 


\section{THE GEOGRAPHY OF UTILITY PROGRAMS}

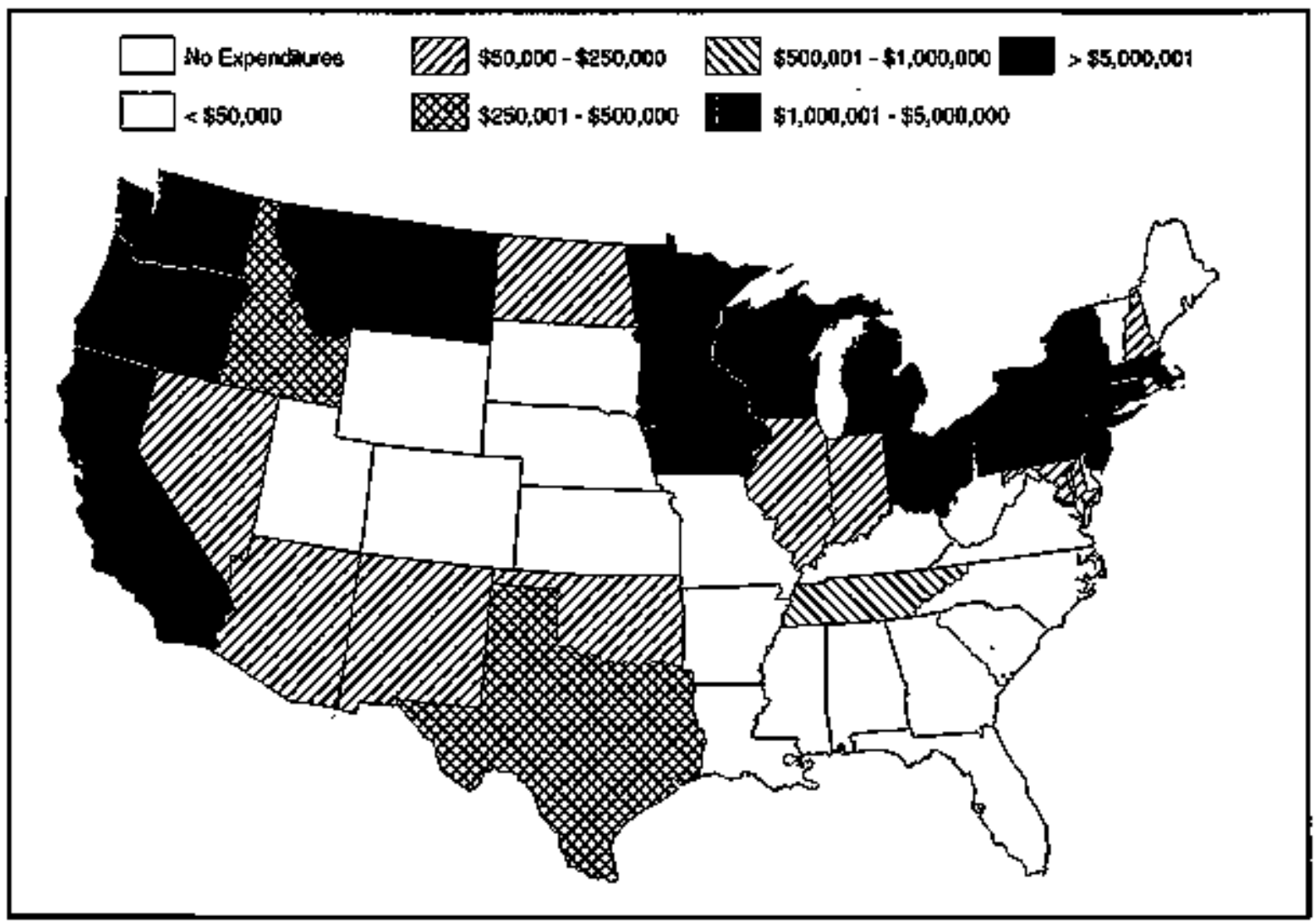

Geographle Dlatribution of Ufility Expentitures on Low-income DSM Pragrams in 1992

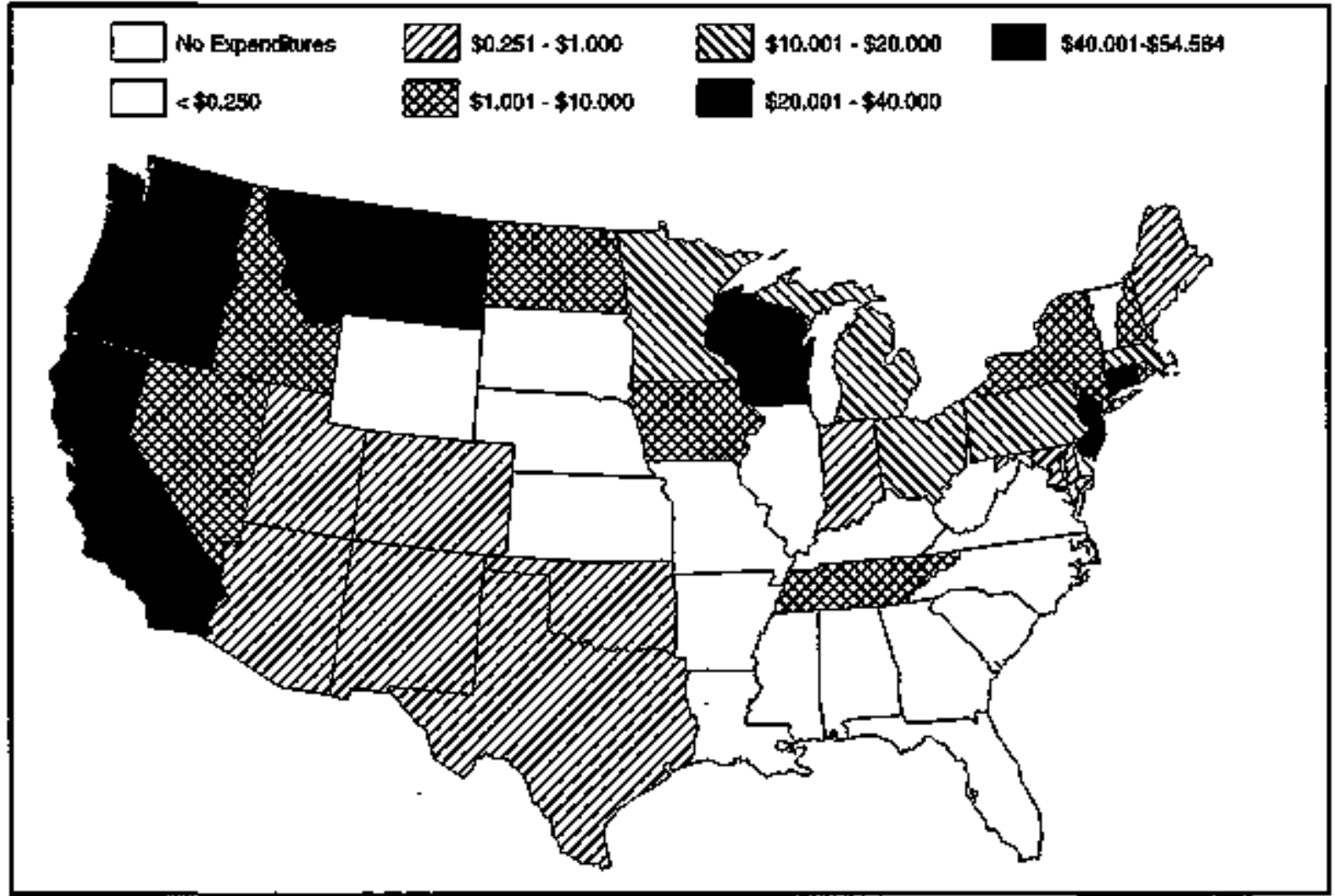

Geographle Disiributlon of Utrity Expendltures Per Low.lncome Housohold tin 1992 


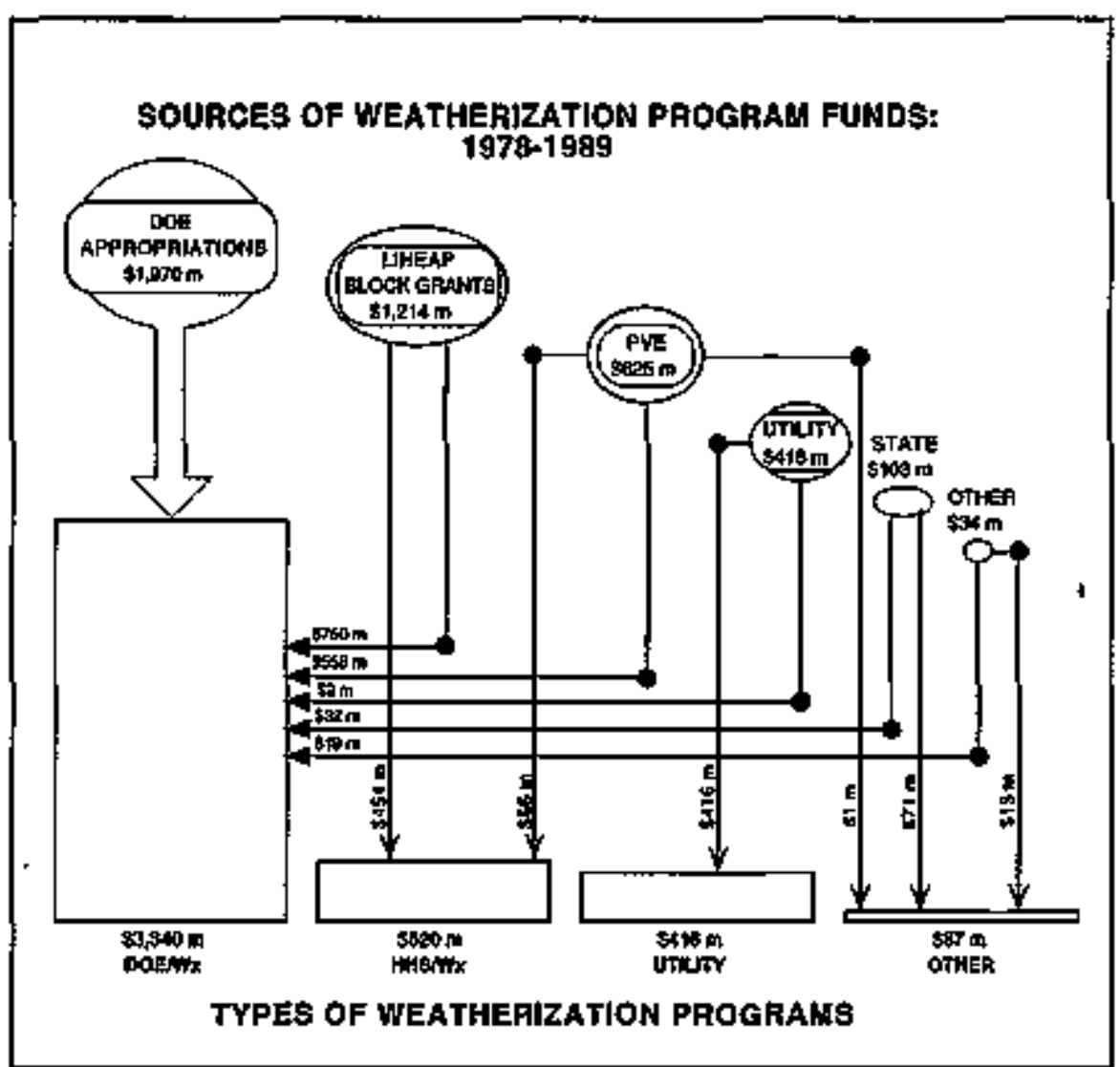

\section{Uses of Funds: DOE Sets the Pace}

Regardless of its source, most funding for low-income weatherization has been spent according to DOE's Weatherization Assistance Program rules. By law, all funds appropriated to the Program by DOE are governed by DOE nules and regulations. In contrast, funds appropriated by LIHEAP can be spent by that prograru's much broader guidelines, which have allowed, for example, greater expenditures on furnace and boiler retrofits and replacements. Similarily, utility low-ircome DSM programs and state funding for weatherization can be spent as the funding agency deems appropriate.

In practice, 77 percent of all low. income weatherizationmoney spentinthe 12-year period between 1978 and 1989 was guided by DOE niles and procedures. Only 12 percent was spent in programs under LIHEAP regulations. The fact that

All Sources of Eanding for Low-Ineorne Weatherizaltion: 1978-1989. Dofinitions of Prograps Types: DOE/WX = fands spent usder DOE Weatherigotion Prograns rales and rezslotions. BHSJWX = furds speat ondar HBS LHEAP gavidefintas and not DOF's riles and regsla-

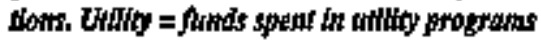
indoponden of DOE's nites and regulations. Oular = funds spost in state weatherization progrants or afier independert progrons. the vast majocity of non-DOE funds have been channeled through the Program underscones DOE's central role in directing weatherization activities nationwide and indicates the importance the new Program rules will have in guiding future weatherization investments.

\section{Utility Partnerships}

Utility programs are making significant, and increasingly important, contributions to the effort to weatherize low-income dwellings. According to Power et al. (1992), 102 utility low-income energy-efticiency programs operated in 1989, with investments totalling $\$ 97$ million (or $\$ 109$ million, expressed in 1992 dollars). By 1992, these numbers had increased to 132 . programs with an annual expenditure of \$141 million (Brown et al., 1994).

Uttlity programs tend to beconcentrated in a few states where weatherization services for low-income customers have been mandated by regulatory bodies. On average, utility-sponsored low-income programs invest about onethird as much per dwelling as the DOE Program. Unlike the DOE Weatherization Program, many of the electric DSM programs for low-income customers focus primarily on lighting and appliance measures. Water-heating measures (particularly low-flow showerheads) are common to both gas and electric DSM tow-income programs. "Major" measures such as attic, wall, and floor insulation and storm windows are less common in these utility programs than in DOE's Weatherization Program. 


\section{PROFILES OF SIX COORDINATED PROGRAMS}

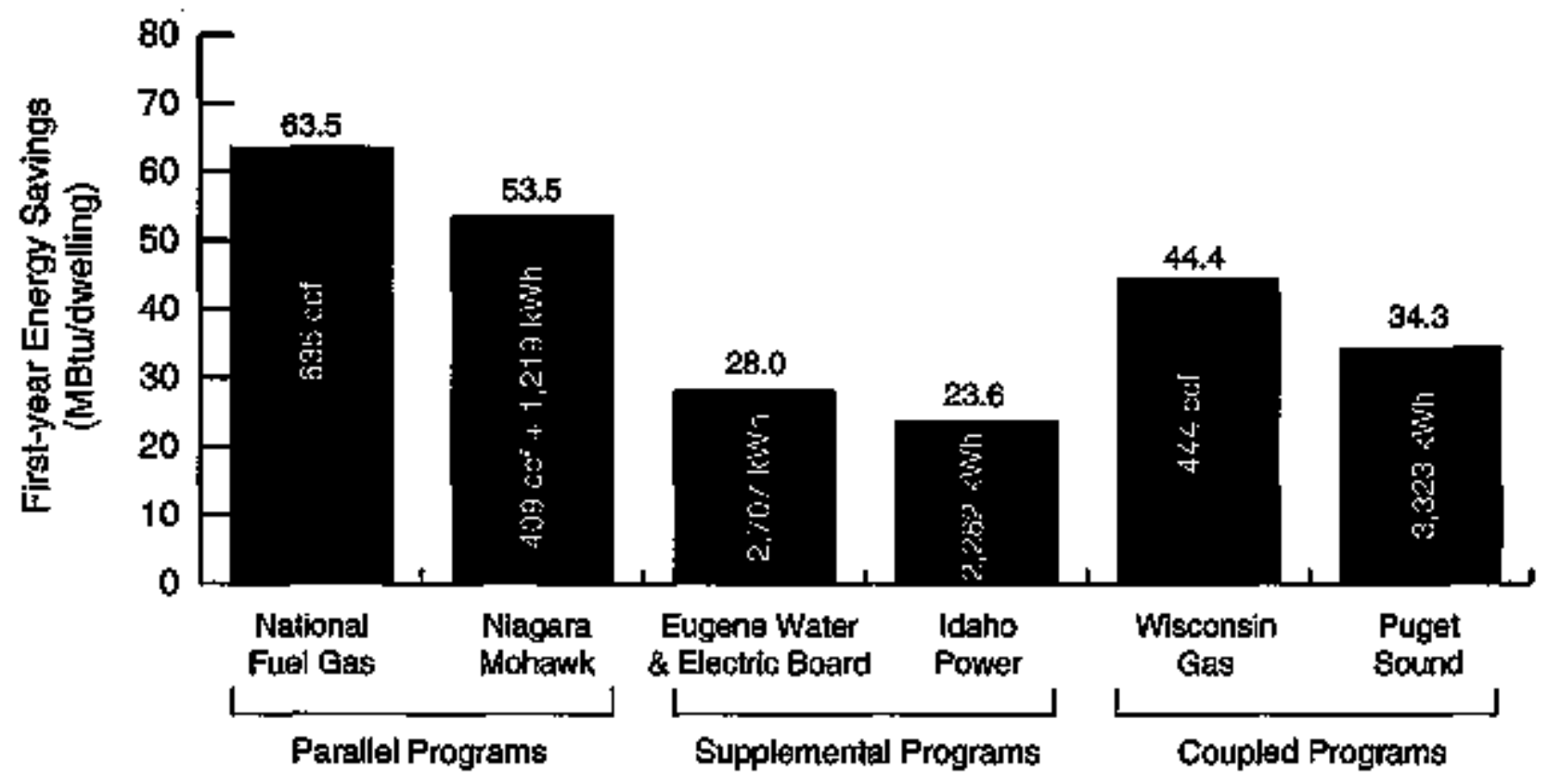

First-Year Energy Savings of Six Coordinated Progams

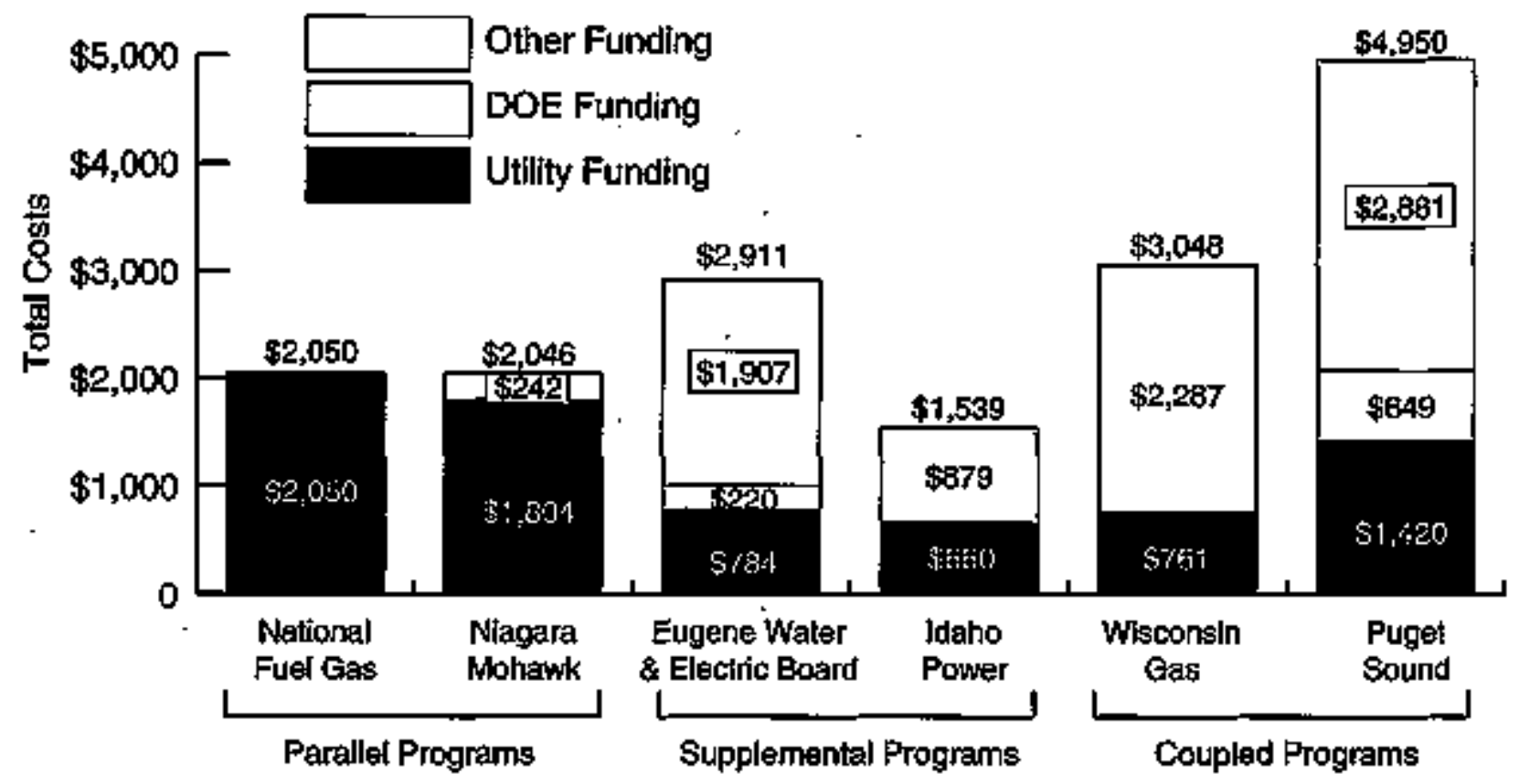

Cosis of Six Coordinated Proprams by Source of Funding 


\section{Utility Partnerships (continued)}

By pooling utifity and govemment resources in "coordinated" programs, utilities are able to offer more comprehensive weatherization to their lowincomecustomers. Three types of utility low-income partnerships exist, which involve varying degrees of coordination between goverment and utility cosponsors (Brown and Hill, 1994).

- Parallel Programs. In these cases, the local weatherization agency operates two parallel programs-one funded by government grants and the other funded by utility contracts. The utility simply employs the agency as a subcontractor to deliver DSM services to Iow-income households. The utility-funded program is coordinated in the sense that some of the same staff and equipment are used by both prograrns.

- Supplemental Programs. These programs use utility funds to supplement the agency's government-funded weatherization program, with no changes to the operation of that program. The result is more weatherized homes, more comprehensive weatherization, or both.

- Coupled Programs. These programs employ a combination of utility and government funds to deliver weatherization services as part of an integrated program that is distinct from the agency's praxisting govemment-funded program. This type of program bas the potential to outperform parallel and supplemental pragrams by taking advantage of the unique capabilities of each cosponsor.

Each of these types of coordinated programs provides utilities with access to trained weatherization professionals and associated equipment, which is often quite sophisticated and conducive to high-quality weatherization. In many regions of the country, there is a scarcity of such DSM capability. In addition, community action agencies are often uniquely qualified to tackle the problems associated with substandard shelter.

Brown and Hill (1994) conducted case studies of six coordinated lowincone weatherization programs. All six programs achieved impressive levels of energy savings. For the three coordinated gas programs, annual savings ranged from 409 to $635 \mathrm{ccf}$ (hundred cubic feet) per dwelling, and for the three electric DSM programs, annual savings ranged from 2,282 to $3,323 \mathrm{kWh}$ (kilowatt-hours) per dwelling. Costs for the $\$$ ix coordinated programs ranged widely from $\$ 1,539$ to $\$ 4,950$ per dwelling. This range of costs is high relative to the amount typically spent in the DOE Weatherization Program, which averaged \$1,550 per dweiling in 1989. In addition, it is much higher than the typical investment levels of standalone utility-operated low-income weatherization programs.

The utilities and community action agencies managing each of the \$ix coordinated programs indicated that the benefits of coordination far outweighed the costs. 


\section{AIR INFILTRATION/EXFILTRATION}

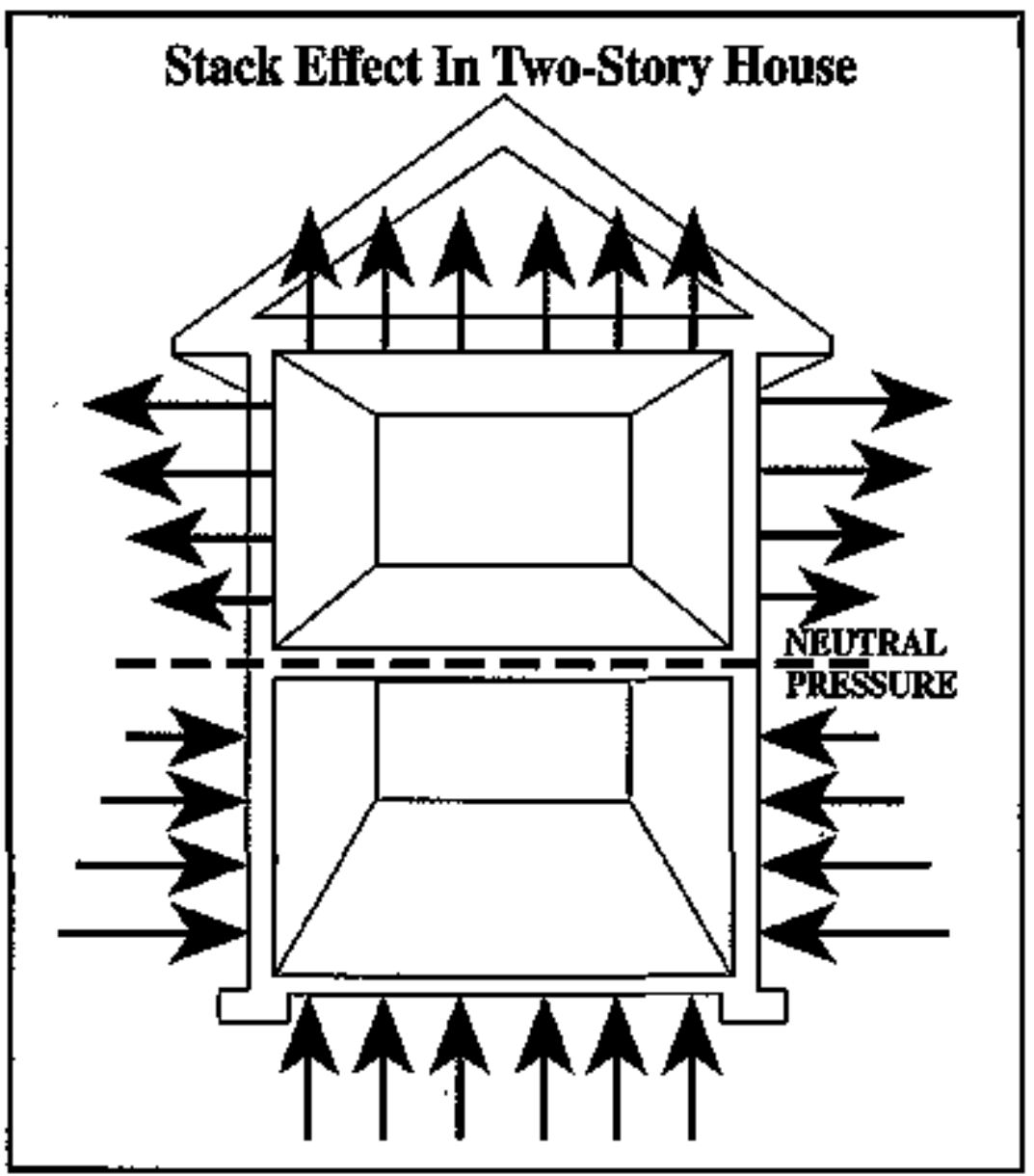

Very leaky hoises are unconfortable and have high energy bills, so funding and curing infiltration problems is a high priority for weatherization operations. The rate of air infiltrationin a home depends on many factors, the most important being the size and location of holes in the thernal envelope and the difference in temperature between inside and outside. Warm air inside a dwelling gives rise to "stack effect" infiltration as warm air tries to escape from the top of the envelope, bringing in cold air at the bottom. Wind and leaks int duct systems can also have a major effect on infiltration, but these effects ate not usually as constant over the heating season as is stack-effect infiltration, which is at its worst on coldest days.

Note that in the middle of the heated envelope there is a neutral pressure zone where neikher infiltration nor exfiltration occurs due tostack effect. This explains why caulling and weatherstripping in mid-envelope tends to save less energy than careful attention to the bottom and top of the envelope, where these natural driving forces are greater. 


\section{THE EVALUATION PROCESS}

The National Weatherization Evaluation is the first comprehensive evaluation of the Weatherization Assistance Program since 1984 (when the I981 Program was evaluated). The evaluation was designed to accomplish the following goals:

- estimate energy savings and cost effectiveness;

- assess nonenergy impacts;

- describe the weatherization network;

* characterize the eligible population and resources; and

- identify factors influencing outcomes and opportunities for the future.

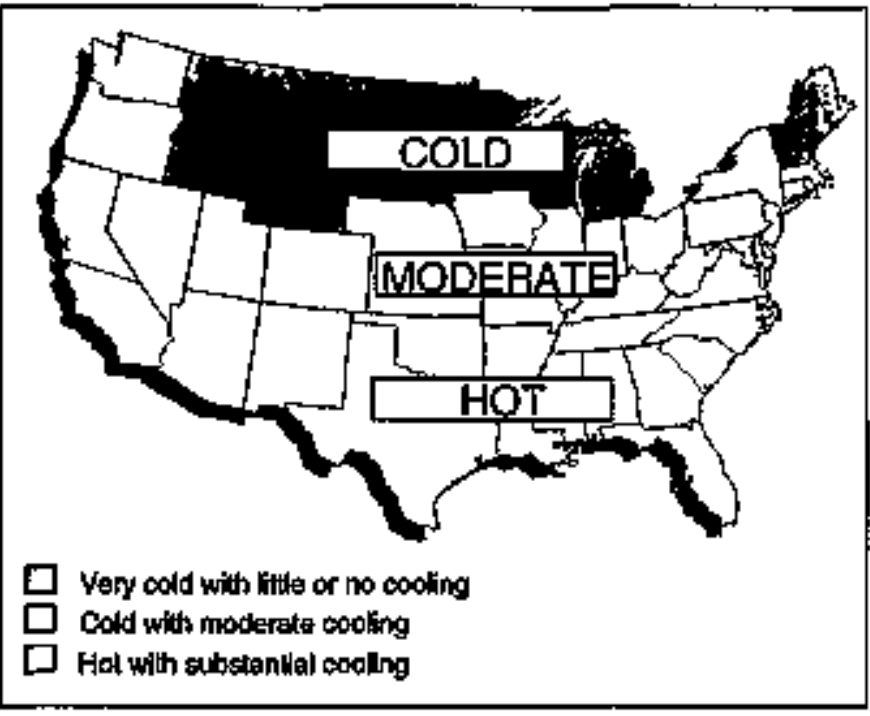

The Natlonal Weatherization Evaluatlon's Thres Clmate Regions.
Working groups with more than 30 nationally known evaluation specialists and conservation program professionals were formed to help define these goals. They gave guidance to the ORNL evaluation team in planning five major studies and in reviewing draftreports. The five studies were as follows:

Single-Family Study-this study estimates the national savings and cost-effectiveness of weatherizang singlefamily and smaIl multifamily dwellings that use nabural gas or electricity for space heating.

Fuel-Oil Study-this study estimates the savings and cost-effectiveness of weatherizing single-family homes in nime northeastem states that use fuel oil for space heating.

Multifamily Study-this study describss the measures used, resources employed, and challenges faced in weatherizing large multifamily buildings.

Network Study-this study characterizes the weatherization network's Ieveraging, capabilities, procedures, staff, technologies, and iruovations.

Resources and Population Study-this study profiles low-income weatherization resources, the weatherized population, and the population remaining to be served.

The findings from each of these studies are documented in a series of eleven reports. References to these reports are at the end of this document

As a national program, weatherization incorporates considerable diversity that springs in large part from regional differences. Therefore, evaluation results are presented both in aggregate and fot three climate regions: cold, moderate, and hot. The Single-Family and the Fuel-Oil Studies both compared the performance of randomly selected samples of weatberized dwellings with samples of similar dwellings that were not weatherized. Appendix A provides further information on the evaluation design and data collected by these two impact studies. 


\section{ADVANCED AIR SEALING}

In the last severat years, it has been shown that some previously ignored areas of dwellings can be potent sonrces of convective losses-and thereby ofter good potential for savings if found and treated. As illustrated in the figures, these include interstices between floors, spaces between the conditioned envelope and such buffer zones as porches and garages, and areas between old and new portions of dwellings. The blower door, in conjunction with a gauge that measures differences in pressure, is a yaluable tool in identifying leakage to or from these areas, helping both in identifying the magnitude of the leakage and in verifying when such measures as the blowing of high-density cellulose or other gir-sealing measures will solve the problem. While only a few weatherization agencies bave integrated these tests and tactics into routine operations, those which have done so achieve excelIent savings.

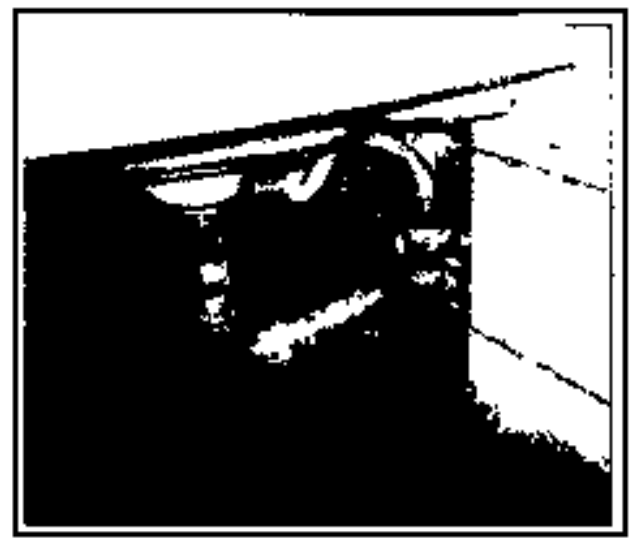

Wole the infiftralion area under the bathrobm sink, which conneots to the atitic vila a situd cavity in an Irierior wail.

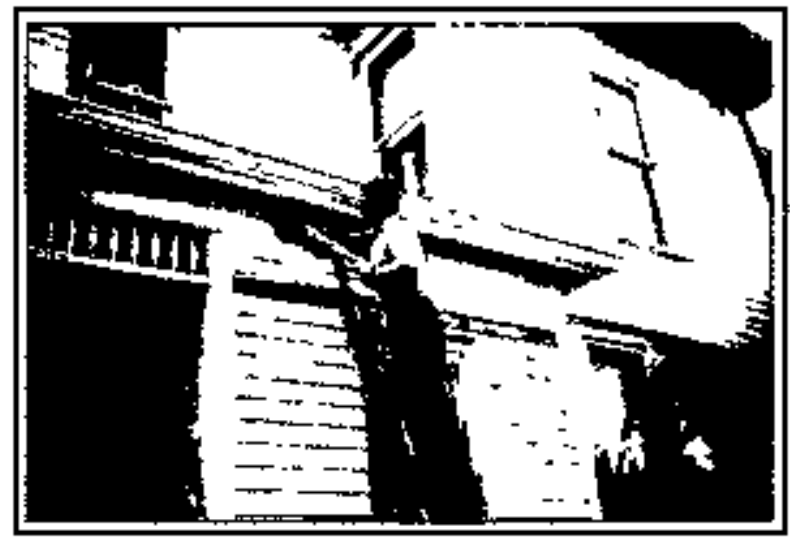

As revealed by a blower door and a presstne gatiga in a test that takes only several minutes, the area under this porat is directly connected to the envelope through flopr jotsis between the first and sacond fioor. High-density insulation is belng used to atr-sed this largest hole in the dweting

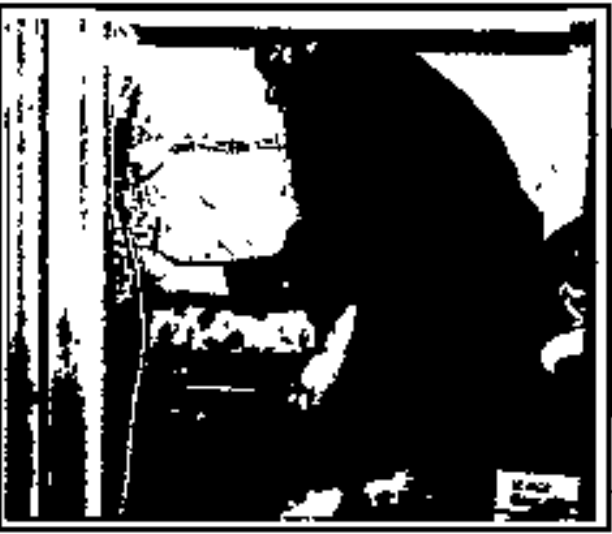

Air soaling a plumbing thase on the first floor that comesponds with both attic and basement. Sealing holes in inconspioiols and hart-to-gotto places are trectuentiy Ihose which resute in sood, costreffective weatherization jobs.

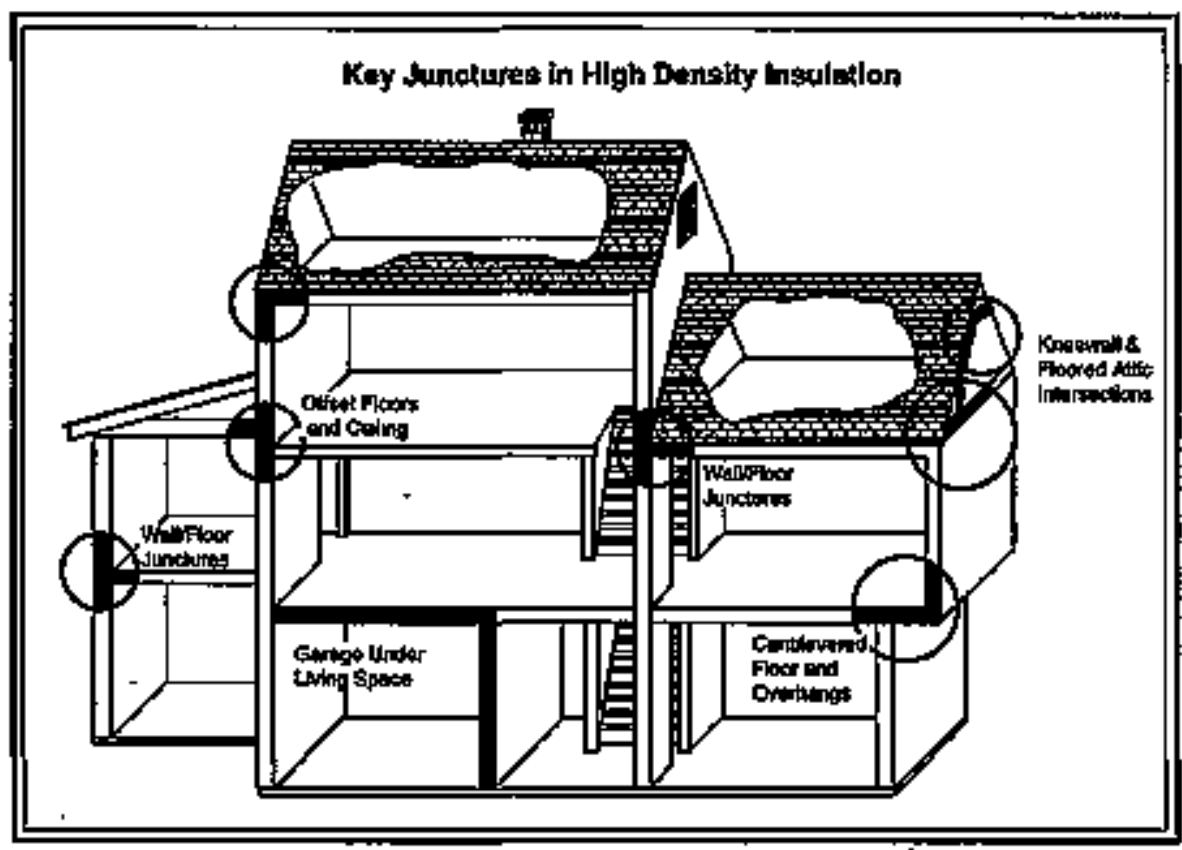




\section{FINDINGS}

\section{A. Diversity of Dwellings and Agencies}

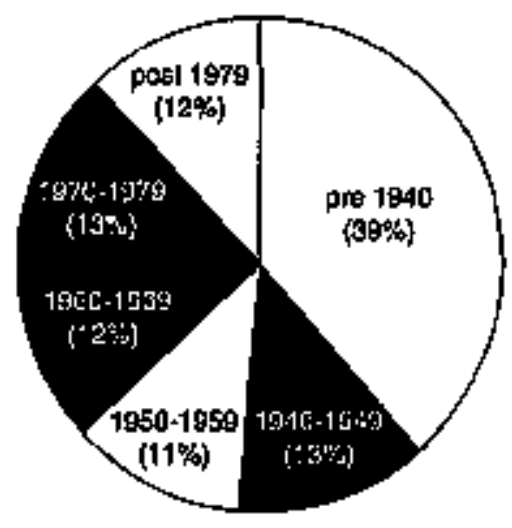

Year of Constrection of Dwelliggs Wentherized in 1989,

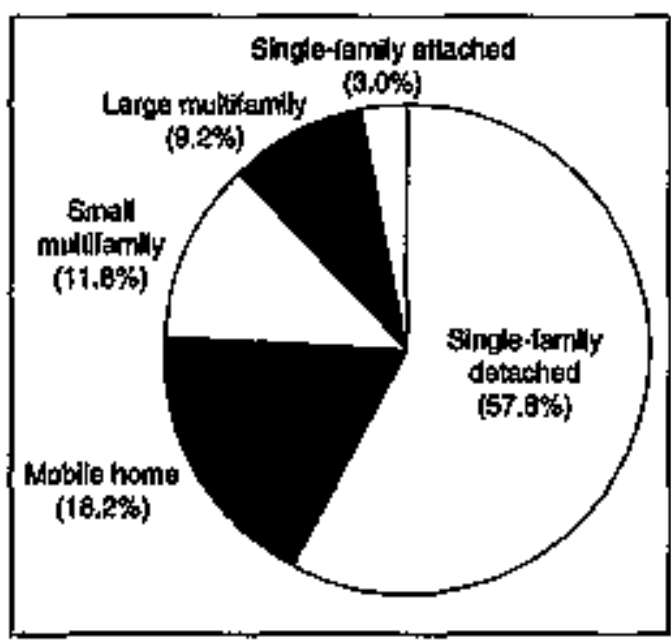

Types of Dwellings Weatberized ln 1969.
Perhaps the most striking finding of the evaluation is the diversity among local weatherization agencies across the country. Same agencies weatherize 15 homes in a year; others weatherize thousands. Some agencies achieve savings of 30 to 40 percent of preweatherization consumption. Others produce no measurable savings. Some agencies employ state-of-the-art procedures, use a variety of funding and techuical resources, and perform sophisticated self-evaluations. Others follow the same procedures year after year, do not evaluate their inpacts, and rely entirely on DOE for funding.

The housing stock addressed by the Program also is diverse. Most lowincome people live in homes built in the decades of cheap energy. Poor insulation and leaky consinction have wasted energy from the stat, and, inevitably, aging makes structures more energy inefficient, more expensive to heat, and often cold, unsafe, and unitealthy. Among the dwellings weatherized in 1989,39 percent were more than 50 years old. On the other hand, 12 percent were less than 10 years old.

Dwellings have been classified into five types. Each type has unique weatherization needs.

Single-family detached homes are the dominant type of structure weatherized by the Program in 1989 (representing 58 percent of the total). Half of these single-family detached units heat primarily with natural gas, and only 10 percent heat with electricity. Elderly occupants reside in 40 percent of these houses, a higher concentration than for any other dwelling type. The vast majority these houses ( 73 percent) are owner-occupied.

Single-family attached dwellings (often called row homes) comprise the smallest housing-type category ( 3 percent of the weatherized population). Almost all are centrally heated ( 93 percent). As a class, these are the oldest buildirgs, with a mean age of 56 years. They also tend to have higher-income occupants and are located almost entirely in the moderate region.

Mobile homes comprise I8 percent of the weatherized population. They are by far the "newest" units, with an average age of only 17 years. They are more likely than any other housing to be heated with anonmetered fael (mainly propare). They are 78 percent owner-occupied and are occupied by individuals with the lowest incomes.

Small multifamily dwellings (those located in buildings with 2 to 4 units) comprise 12 percent of the weatherized population. They are heated primarily with natural gas (73 percent) and are typically renter-occupied ( 82 percent). Compared to single-family detached homes, they are oniy half as likely to have an elderly or handicapped occupant.

Large mnltifamily dwellings comprise 9 percent of the weatherized population and represent a distinct building type. They are located almost entirely in the moderate and cold regions (approximately half are located in New York City), and they tend to be older than the single-fanily dwellings weatherized by the Program (52 percent vs. 38 percent were built before 1940). They are almost all centrally heated by gas, electricity, or fuel oil. 


\section{BLOWER DOORS}

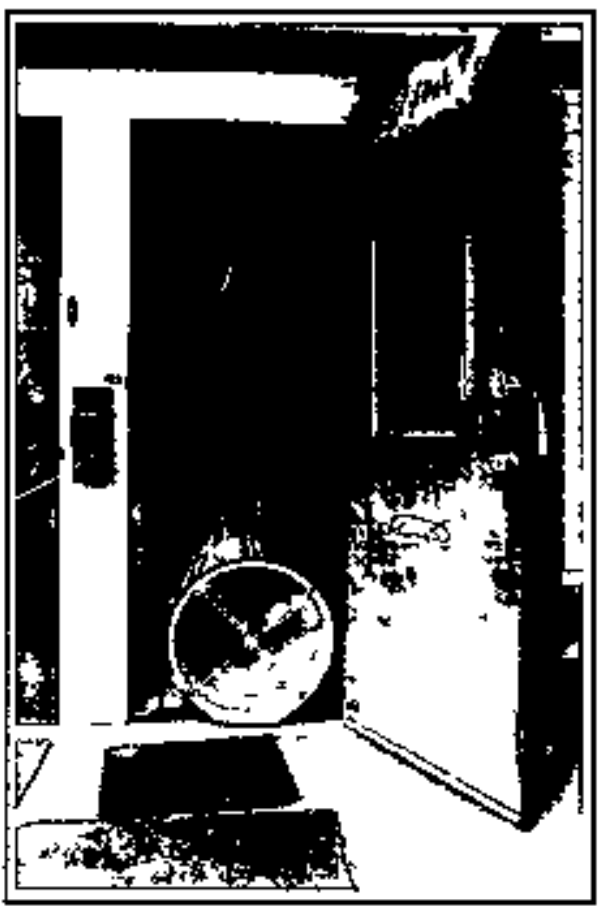

Blower door aekup, outside view.

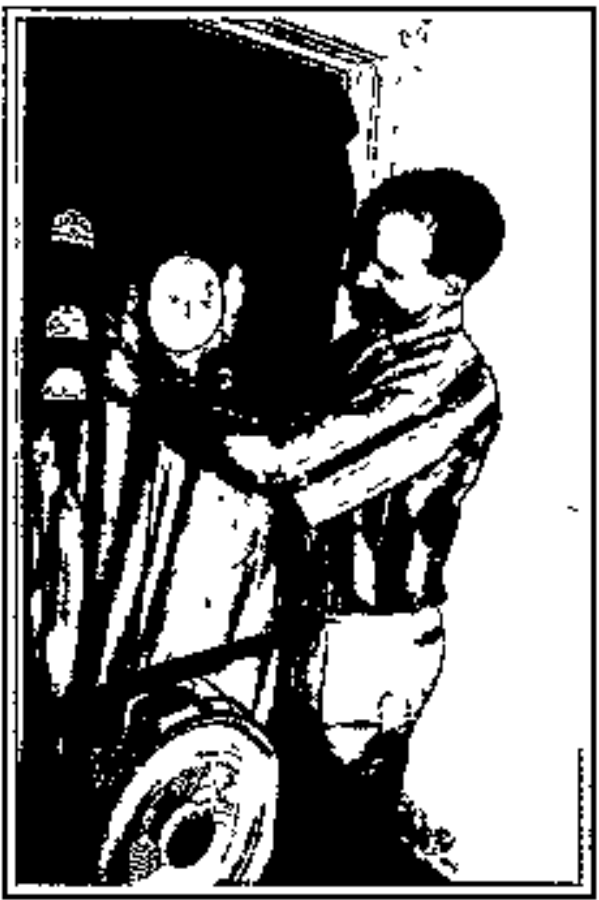

Blowiter door setup, inside vlew. The lechmician is zeroing the geugges, so as to moasure both air fikew end tho insidtoutside pressure difference caused by the blower choor. This speed of the fan is adjusted using the control on top of the tan.
Blower doors are variable-speed fans equipped with a frame and shroud that permits them to fit inside a variety of door frames. Instrumentation includes pressure gauges that enable the operator to determine the flow of air through the fan as wel] as the pressure the fan induces on a dwelling. Since leakier houses require more air flow to induce a given pressure difference, blower doors can measure the relative leakiness of a house. When used as a diagnostic instrument, they can also reveal the location of many leaks, thus providing a clear target for air sealing.

When the job is partially of fully complete, blower doors also provide technicians with fast feedback on the effectiveness of their work, thus contributing to increased practical wisdom on the part of the technicians and to the overall professionalization and efficiency of the weatherization process itself.

Experience has shown that high preweatherization blower door readings of flow (at a standard pressure of 50 pascals, for example) are strongly correlated with success in air sealing, as revealed by substantially lower postweatherization blower door readings.

Signifticantly, blower doors are aiso useful in revealing what does not need to be done, allowing weatherization crews to concentrate on real problems. This observation illuminates critical features of the evolution of the weatherization program and building science.

Prior to the advent of blower door technology and the detailed analysis of patterns of convective energy losses, conventional wisdom held that most air leakage Dccurs toward the mid-height of the conditioned envelope, pimarily through doors and windows. Accordingly, application of weatherstripping and caulking in those areas was advocated in DOE instructions and related publications and was widely practiced by weatherization techricians and others. In the early days of blowerdoor-aided diagnostics and air sealing-which for most weatherization agencies included the period of this evaluation-these practices continued. In fact, blower doors do reveal leaks from doors and windows, although their effects are amplified, since small areas resultinhigh-velocity air currents. Gradually, however, it was discovered that leakage from doors and windows represents a relatively small percentage of convective losses in most dwellings, and that genuinely serious leaks tenderd to occur at the bottom and (especially) the top of the conditioned envelope. Accordingly, careful gir sealing in attios and basements is increasingly practiced by weatherization crews in most areas of the country. The use of blower door technology should be periodically evaluated at the local level to ensure that the technology promotes cost-effectiveness in various circumstances. 


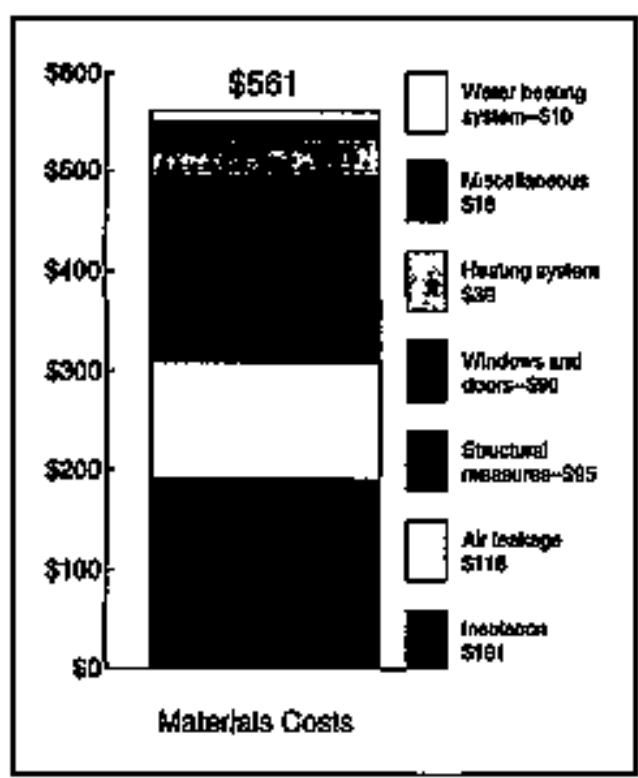

Cust of Malertals to Weatherize a Typical Dwelling in 1989.

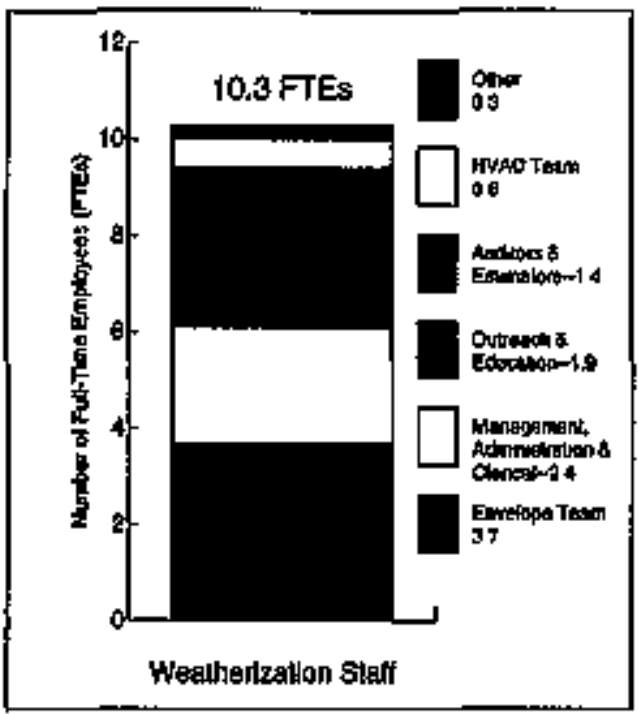

Weatherization Staff Employed by a Typical A gency in 1989.

\section{The Typical Dwelling}

The typical dwelling' weatherized by DOE's Program in 1989 was a 51year-old, single-family detached dwelling in the moderate region with 1,193 square feet of heated space. The three-person household living in the house had an income of $\$ 7,641$. Prior to weatherization, the typical dwelling was heated by an inefficient gas furnace (with a 75 percent steady-state efficiency). The dwelling had significant air leakage (1.3 air changes per hour) and linated, if any attic, wall, or floor insulation.

Weatherization for this dwelling consisted of installing insulation (primarily in the attic and walls), along with air leakgge reduction and water heating system efficiency measures. Incidental repairs and health and safety measures were also performed. The dwelling received $28 \mathrm{crew}$ hours of weatherization labor and $\$ 561$ of weatherization materials. After weatherization a quality control check was performed.

In the first year after weatherization, the typical dwelling saved $2030 \mathrm{cf}$ of natural gas, or 15 percent of its preweatherization gas consumption and 21 percent of the gas it uses for space heating. Over the lifetime of the measures, the typical dwelling will save 4,060 ccf of gas, or slightly less than four years' worth of home heating fuel.

\section{The Typical Agency}

The typical agency ${ }^{2}$ involved in the Weatherization Assistance Program is located in the moderate region, and weatherized approximately 350 homes in 1989 , most of which were single-family, detached dwellings heated primarily with natural gas. This definition of the typical agency excludes agencies in the less popnlous hot and cold climate regions, agencies that serve densely populated metropolitan areas, and small agencies that serve one or two rural counties.

Based on 1989 data, the typical agency is a Community Action Agency that receives weatherization funding of almost $\$ 600,000$ from multiple sources, including DOE, PVE, and to a lesser degree LIHEAP. Operating two crews, the typical agency weatherizes nearly two homes each work day. The staff of 10 full-time employees includes energy auditors; envelope crews with a crew chief; client outreach and education staff; management, administrative, and clerical staff; and other techrical and nontechnical staff, which may include a beating system specialist.

The typical agency also performs other services for about one-third of its weatherization clients, which might include installing smoke detectors or door locks. In addition, the typical agency refers about one-third of its clients to other public prograns that offor such services as nutrition, health, fue] assistance, employment, and job training. 


\section{DENSE-PACK CELLULOSE}
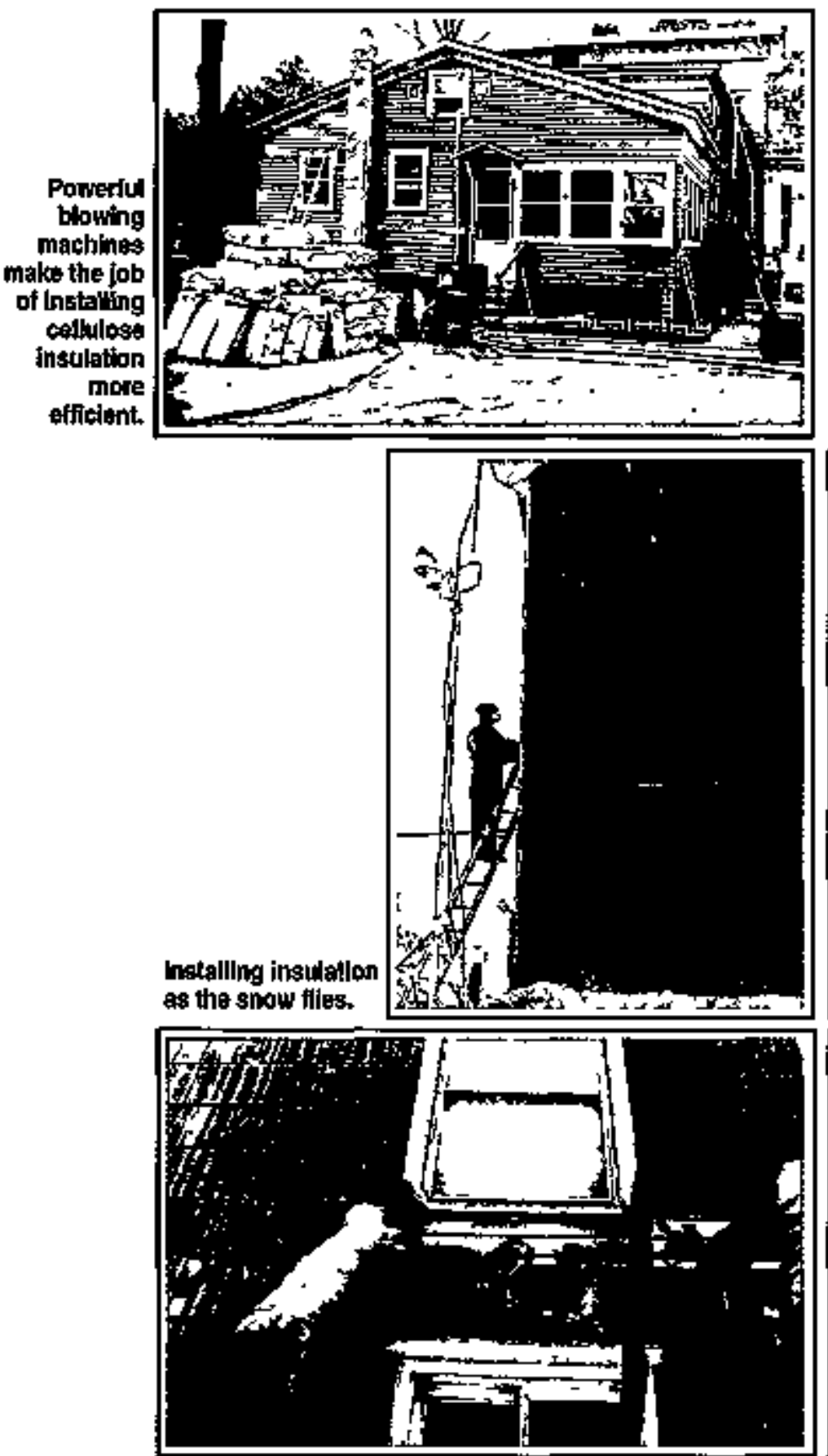

Preparallon, Insulation, and cleanup kaeps two weatherization toam menters working for most of a dey.
Installing cellulose at high density has been found to be a powerful technique for installing insulation and achieving air sealing at the same time. Many crews find that the infiltration rates of some houses can be cut in half without using a tube of caulk. The secret is careful installation of high-density cellulose in wall cavities (and other places where it really counts) with a tube inserted directly where the insulation needs to go-and using power blowing machines to packit in tightly. In PY 1989, most agepcies had not yet incorporated this technique into their weatherization operations, but more recent analyses conducted in this evaluation (the Fuel-Oil Study and the analysis of high-performing agencies) suggest that these newer neastires save considerable energy.

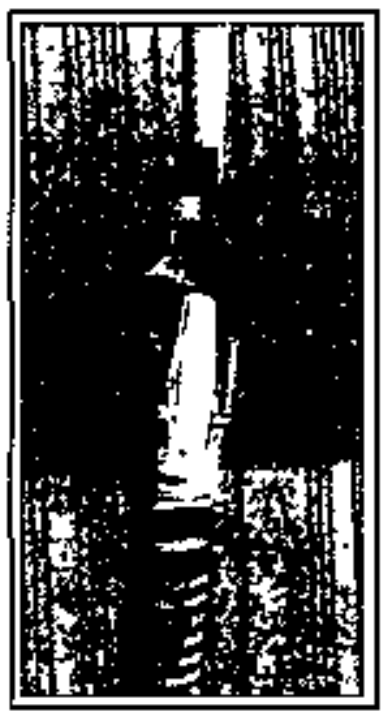

The small tube at the top is snaked Indo wall cavlties, then slowly withdram gs instaliton filis them up. The result is a very tight fill.

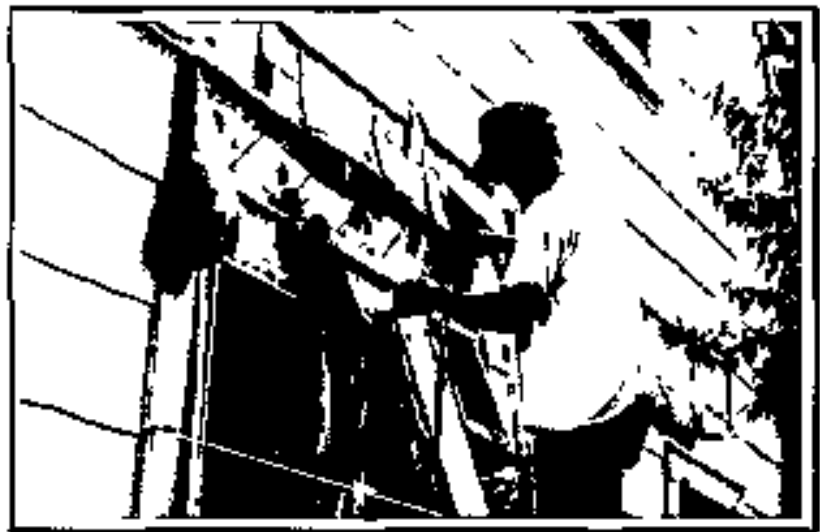

Wat proparation. Shingles are postloned for fas! realtachiment aftor insulation blowing. 


\section{B. Program Benefits}

\section{National Energy Savings}

During Program Year (PY) 1989, the Program weatherized 198,000 single-family or small multifamily homes, resulting in net energy savings during the following year equivalent to 601,000 barrels of oil, or almost 1,650 barrels of oil per day. ${ }^{3}$ Orer the estimated 20-year lifetime of the weatheriza-

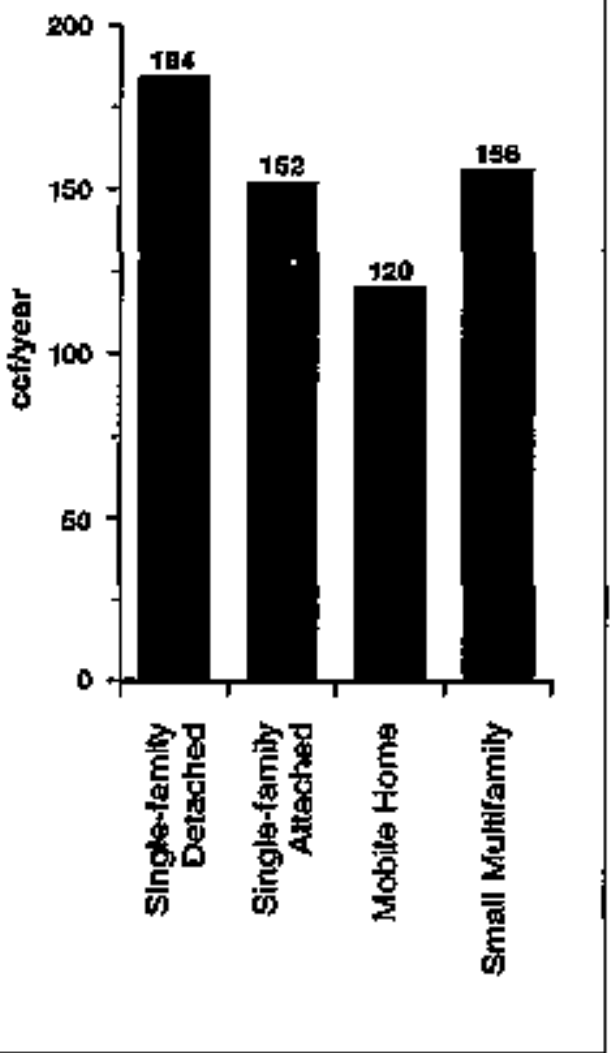

Net Gas Savings by Types of

Dwellmgs Weatherized in 1989. ton measures, net savings from Program expenditures in 1989 are projected to be 69.7 trillion Btus, the energy equivalent of 12 million barrels of oil. These estimates are based on measured reductions in the use of primary heating fuels after weatherization. Savings of supplemental heating fuals were not measured.

Gas-heated dweIlings account for 50 percent of the dwellings weatherized by the Program in 1989 . It is estimated that the Program, which addresses orly space heating and sometimes water heating energy efficiency, saved 18.3 percent of the gas used for space heating. This represents 13.0 percent of total gas use, including water heating, cooking, and other gas-appliance uses. Variations in savings by dwelling type were significant. For example, singlefamily detached dwellings (the dominant dwelling type served by the Progrant) saved over 50 percent more atatural gas per dweling than did mobile homes.

Electrically heated homes represent only 10 percent of the dwellings weatherized under the Program during 1989. Weatherization of these dwel]ings saved 35.9 percent of the electricity used for space heating. This represents 12.2 percent of total electricity use. As with gas-heated homes, both single-family detached and small multifamily dwellings saved more electricity than did mobile homes.

The Furel-Oil Study showed that an average single-family dwelling located in the Northeast and heated primarily by fuel oil saved 160 gallons of fuel oil in the first year following weatherization. This is equivalent to 22.4 million Btus, or 17.7 percent of

Net energy sarings for single-family and small mulfifamily dwellings weatherized in 1989

\begin{tabular}{|l|c|c|c|}
\hline Prinary heating fivel & $\begin{array}{c}\text { Percentage of } \\
\text { space heat }\end{array}$ & $\begin{array}{c}\text { Percentage of } \\
\text { total fuel use }\end{array}$ & $\begin{array}{c}\text { Net savings } \\
\text { (M/Btw/year) }\end{array}$ \\
\hline Natural gas & 18.3 & 13.0 & $17.3 \mathrm{MBtw} /$ year \\
\hline Electricity & 35.9 & 12.2 & $18.9 \mathrm{MBtw} /$ year \\
\hline Fuel oil (Northeast) & 17.7 & 17.7 & $22.4 \mathrm{MBtw} /$ year \\
\hline All fivels* & 18.2 & 13.5 & $17.6 \mathrm{MBtw} /$ year \\
\hline
\end{tabular}

*Includes estimates for propane, wood, kerosene, coal, and other fuels. total fuel-oil use. (Fuel oil is generally used only for space heating.)

Measured savings for gas, electricity, and fuel oll were conbined with estimates of energy savings for dwellings that heat primarily with other fuels such as propane, wood, kerosene, and coal. The average savings for all single-fanily and small moltifamily dwellings weatherized in 1989 was estimated to be 17.6 million Btus per year, 18.2 percent of the energy used for space heating and 13.5 percent of total energy use. 


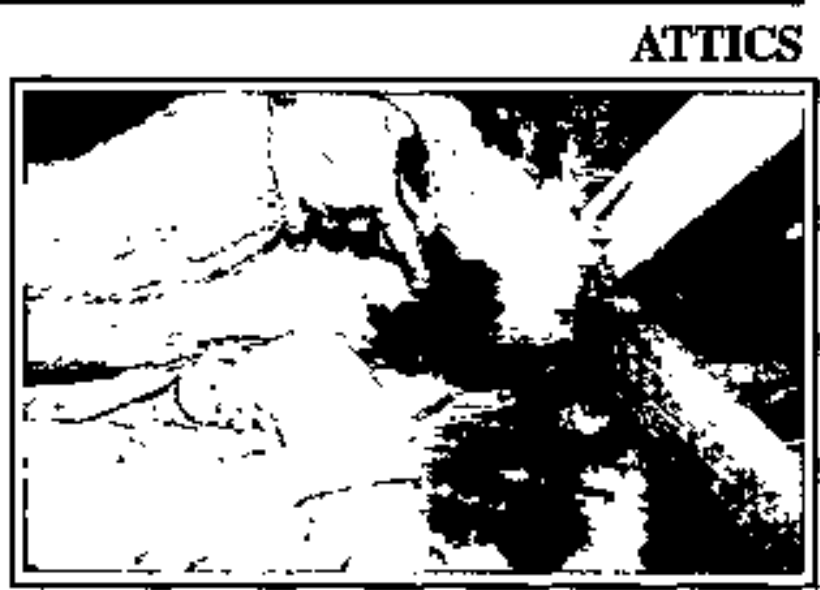

This ts a i2-inch flberglass bath that has been on top of a small crack In the celling bolow for only one winter. The dirt is from the passing of massive amounts of air driven by stack-effect extlitralion.

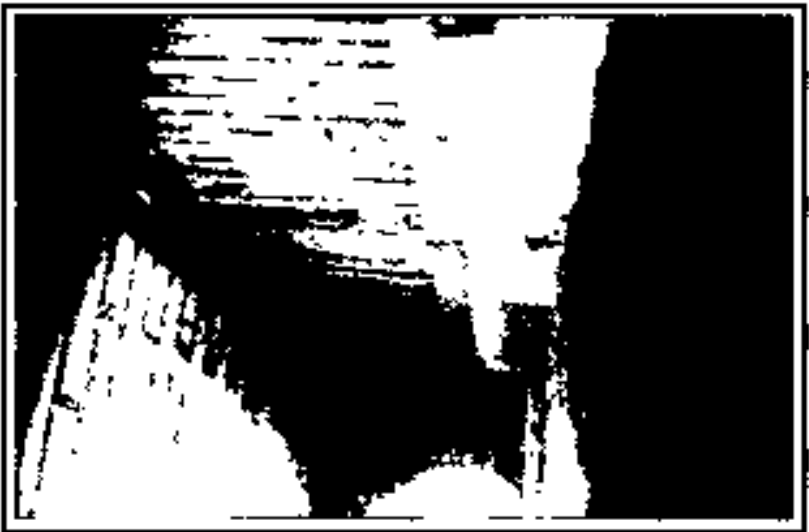

This space befween the chimney interior freming is completely open to the attlc. Seallng thls at the level of the aftio insulation is likely to save more energy than teptacing every willow in the twrelling. An experenced weattierization crew tochricien can thor. ough'y (and safaly) seal this opening in 15 minutes whith a material cost of \$4.
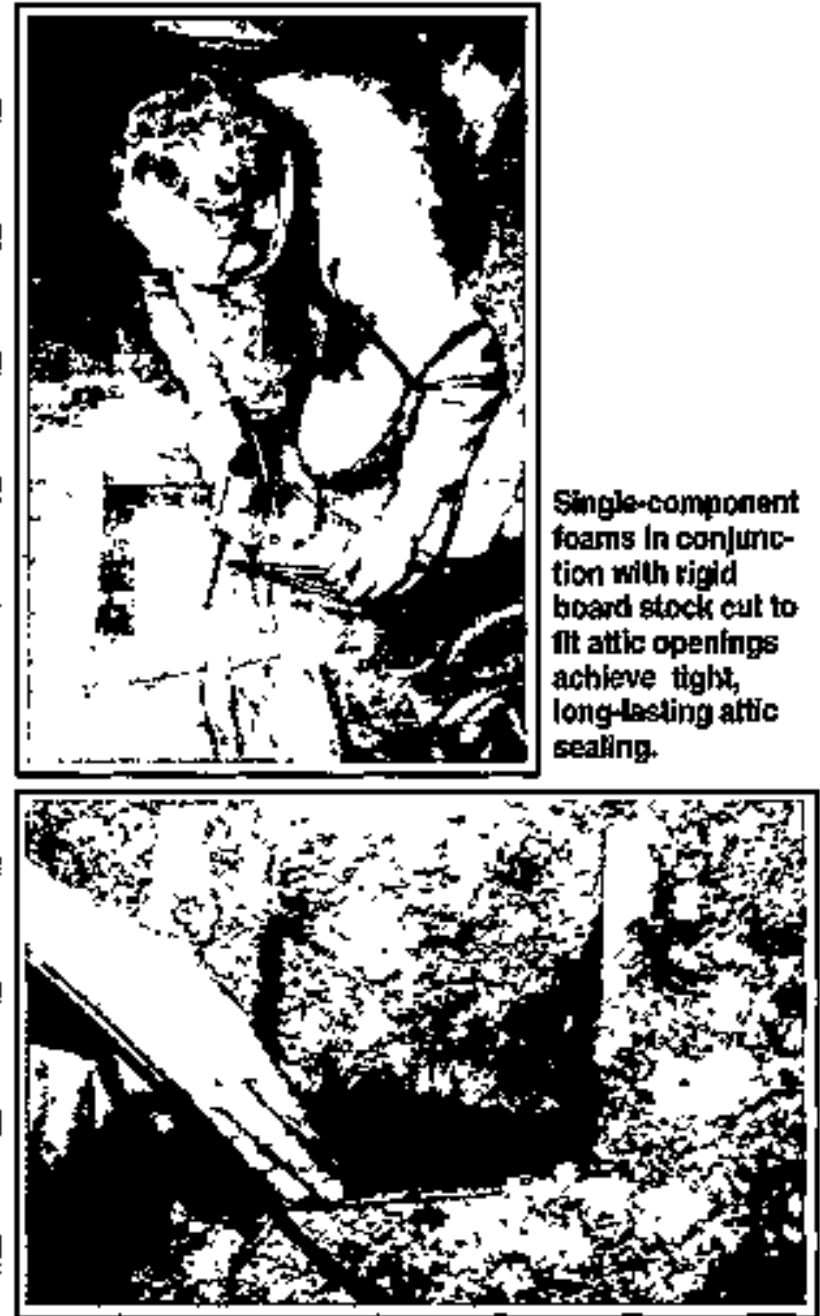

Irterior wells open to attics are corrimonptace-and must be sealed to prevent thermal siphoning. If this bale is not sealed during wealhorlzallon, the Interlor wall bolow is likely to be much coldar In the winter than exterior insulated walls. 


\section{Nonenergy Benefits}

The Program's weatherization activities have numerous benefits beyond reductions in energy consumption. Improvements to dwellings often raise the health, safety and comfort levels of occupants as well as increase the value of their homes. Reducing energy denuand decreases the environmental impacts of energy production. In addition, lowering energy consumption produces a variety of economic benefits such as a reduced energy burdens, more funds for other expendinures, and increased employment. In this section, information on selected nonenergy benefits is discussed.

Occupant perceptions of the health, safety and comfort of their homes were much improved after weatherization. Occupants of weatherized and control homes were asked to rate the comfort, draftiness, safety, and heating expenses for their homes. They also were asked to rate their own health (in terms of the incidence of illnesses, such as colds, flu, allergies, headaches, nausea, arthritis, which may be af-

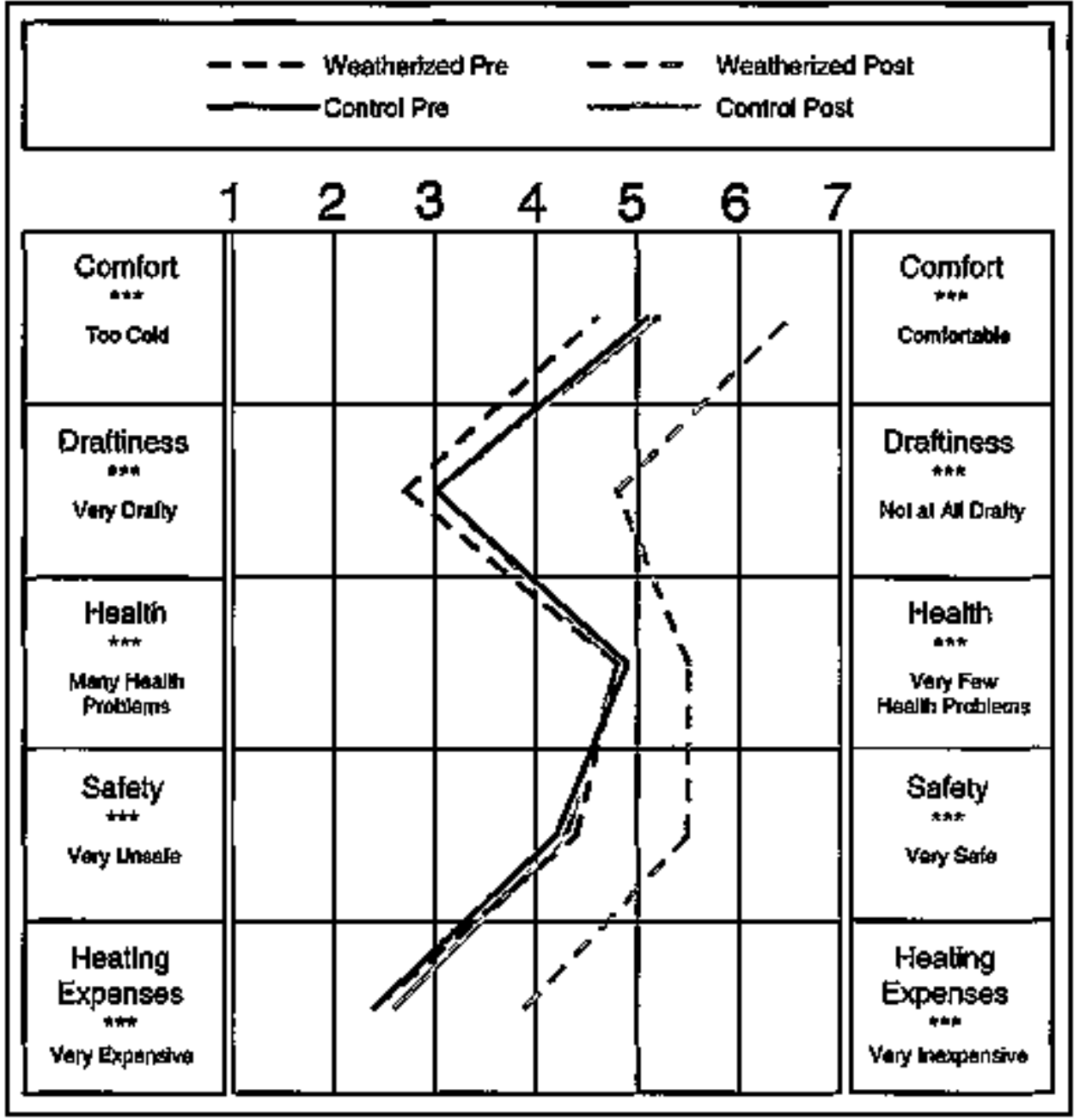

Occupant Perceptions of Nonenergy Bestefits of Weatherizationt in Weatherized and Control Dwellings fected by the temperature, $\mathrm{CO}$ lev. els, or draftiness of the dwelling).

On every rating scale the weatherized group reported a highly significantand positive change between the before and after weatherization time periods. The control group, on the other band, reported no change in any of the ratings. Thus, the weatherization clients experienced improvements in the comfort and safety of their homes, while the control group did not. The weatherized group also beljeved their homes became less drafty and their heating biIls more affordable after weatherization. The control group said there was no change during the sarne time periods. Finally, the weatherized group feit that there had been an inprovement in their own health, while the control group did not.

Although it is difficult to place a monetary value on these health, safecy, and comfort benefits, accupants of weatherized dwellings recognize and appreciate them. 


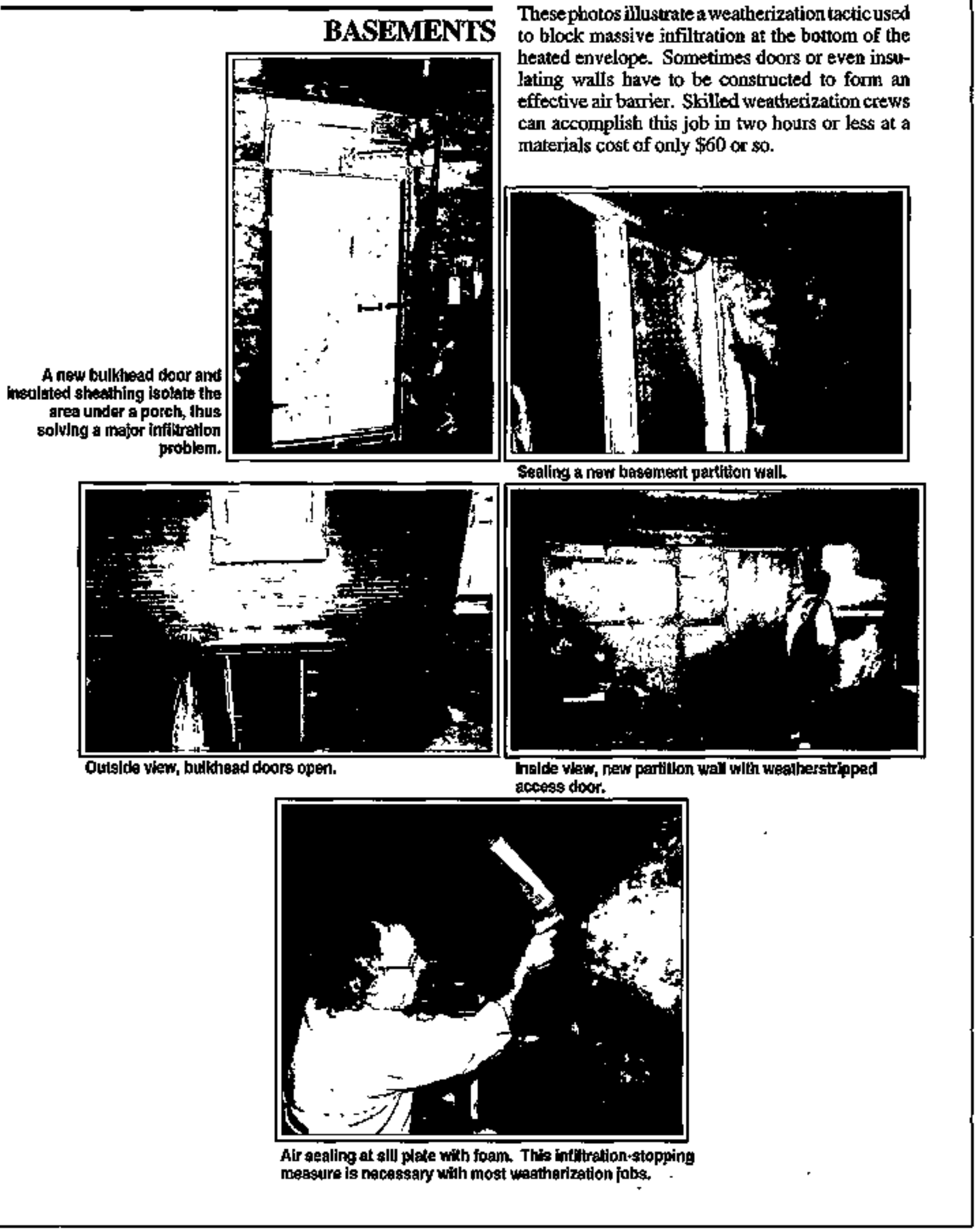




\section{Nonenergy Benefits (cont.)}

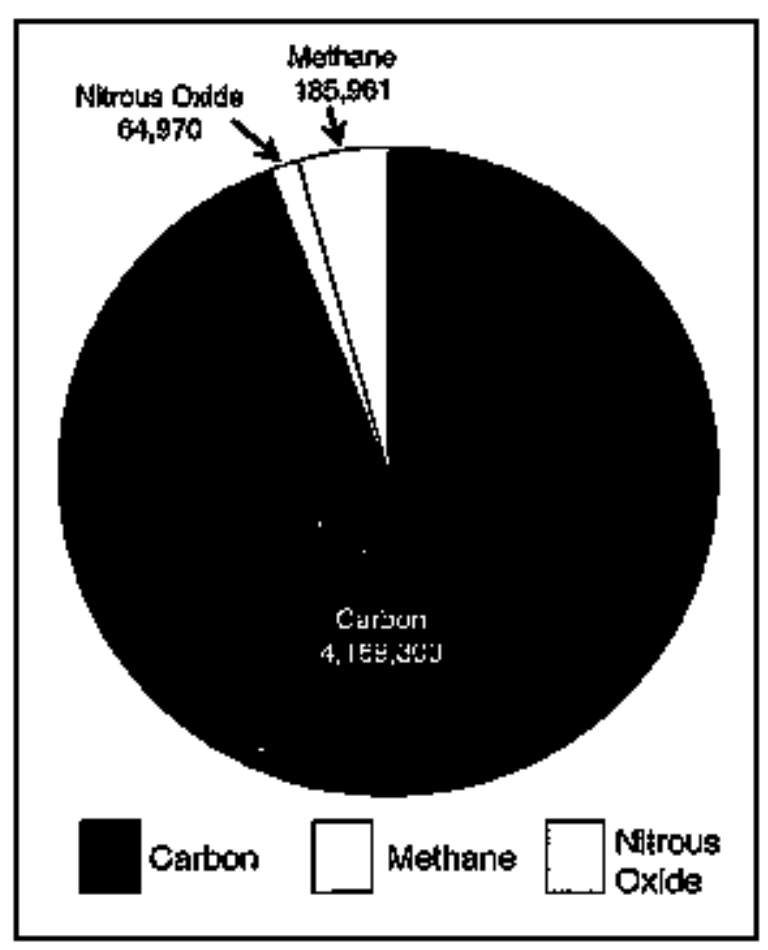

$\mathrm{CO}_{2}$ - -quivalent emission reductions of

1989 Program, by type of greenhouse gats.

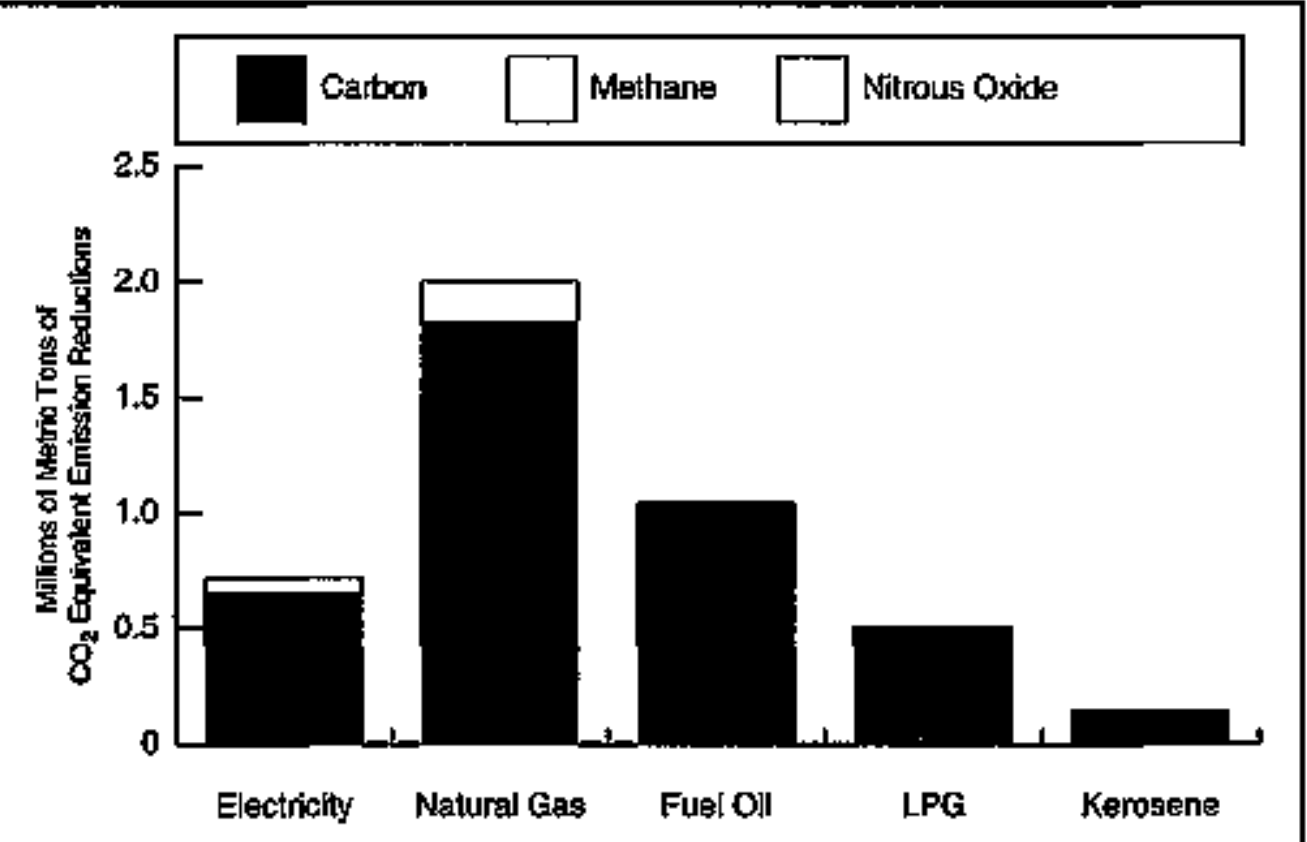

$\mathrm{CO}_{2}$-cquivalent emission reductions of 1989 Program, by type of heating fuel
Environmental benefits from weatherization include the reduction of greenhouse gas emissions. The principal gases of concem from the perspective of global warning are carbon dioxide $\left(\mathrm{CO}_{2}\right)$, methane ( $\mathrm{CH}_{4}$ ), and nitrous oxide $\left(\mathrm{N}_{2} \mathrm{O}\right)$. The following calculations are based on dwellings weatherized in 1989 that heated primarily with electricity, natural gas, fuel oil, LPG, or kerosene.

Weatherizing a dwelling that heats primarily with natural gas reduces carbon omissions by 0.2489 metric tons per year. Those heating with electricity reduce carbon emissions by 0.475 metric tons per year, assuming that emissions from electricity generation are equivalent to those from binminous coal combustion. The carton enission reductions per dwelling unit for fuel oil, LPG, and kerosene are $0.445,0.263$, and 0.306 metric tons of carbon, respectively. These estimates translate into $\mathrm{CO}_{2}$ emissions 3.67 times higher because of the additionat weight of the two oxygen atoms.

Methane has 35 times the warning potential of $\mathrm{CO}_{2}$. If the entire cycle of production, transmission, distribution, and household enduse is included, a typical weatherized dwelling, heated primarily with natural gas, will reduce methane emissions (in $\mathrm{CO}_{2}$ equivalents) by 0.090 metric tons per year. The emission reductions from the other types of heating frels are much smaller.

Electricity genteration is the only source of nitrons oxide emissions that is relevant to home heating. Weatherization yields an annual reduction is $\mathrm{N}_{3} \mathrm{O}$ emissions of 0.173 metric tons per electrically heated dwelling, in $\mathrm{CO}_{2}$ equivalents.

The 1989 Program as a whole reduced the equivalent of more than 4 million metric tons of $\mathrm{CO}_{2}$ over the lifetime of the measures. The amount of $\mathrm{CO}_{2}$-equivalentemission reductions due to various types of heating fuels and greenhouses gases are shown in the figures on this page. Since most of the dwellings weatherized by the 1989 Progzam were heated pri-

marily with natural gas, these dwellings are responsible for the biggest share of the $\mathrm{CO}_{2}$-equivalent reductions. They are also the only dwellings with a measurable methane impact. Carbon reductions account for the vast majority of the Weatherization Program's reductions of $\mathrm{CO}_{2}$-equivalent greenhouse gas emissions. The next largest greenhouse gas impacted by the Progran is methane. 


\section{HEALTH AND SAFETY}

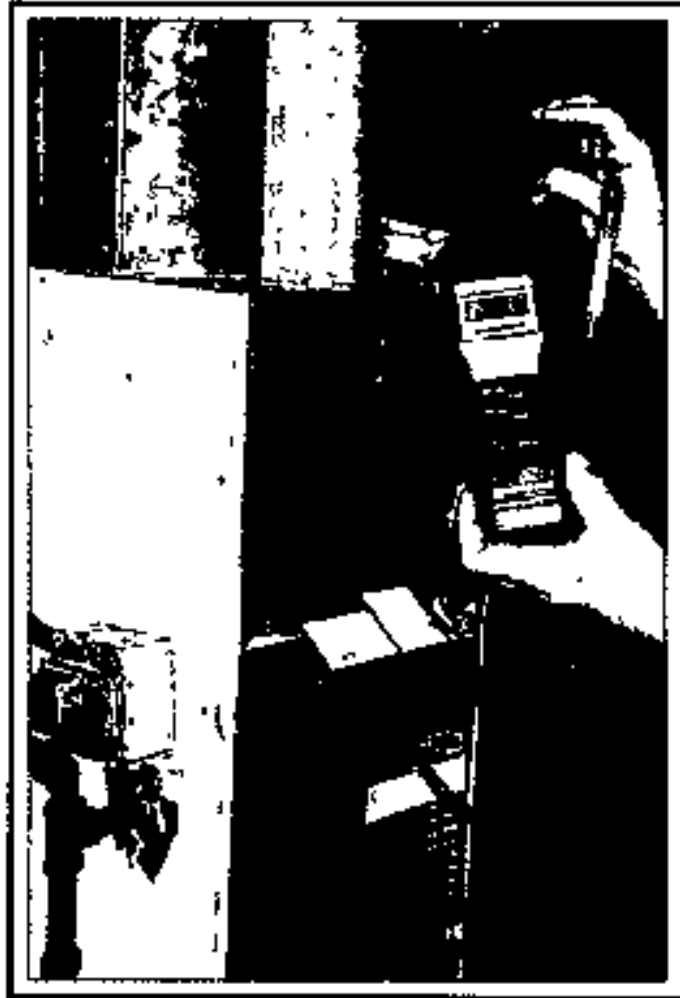

Tesking tor carbon monoxiditi insures both fumace efifictency andi sadety.

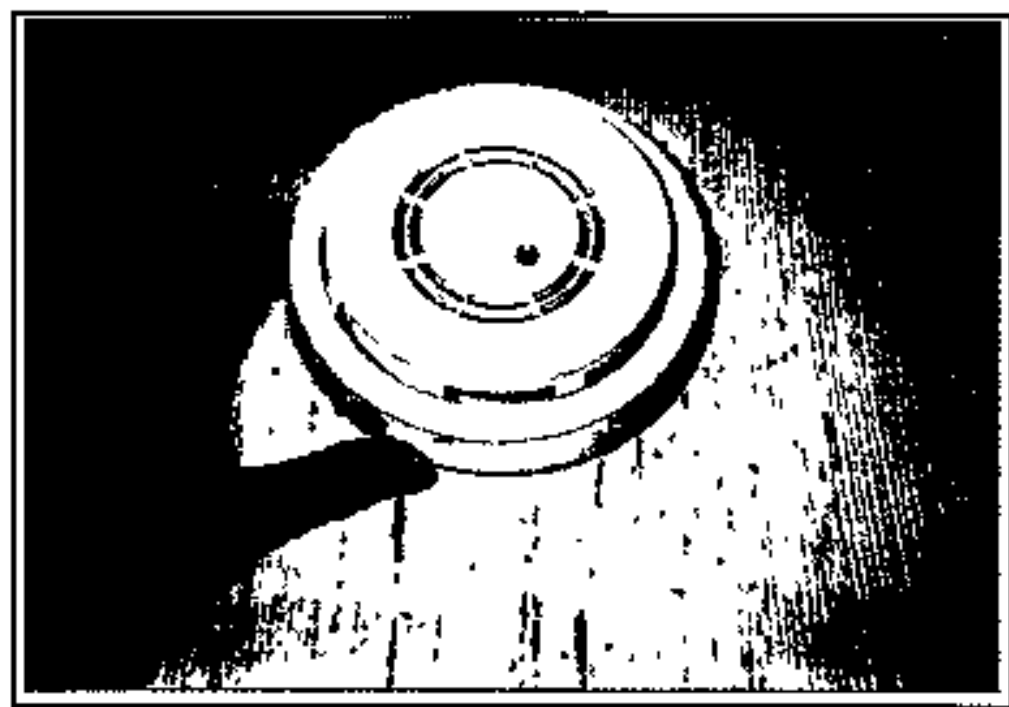

Smoke akarm installations improve salety.

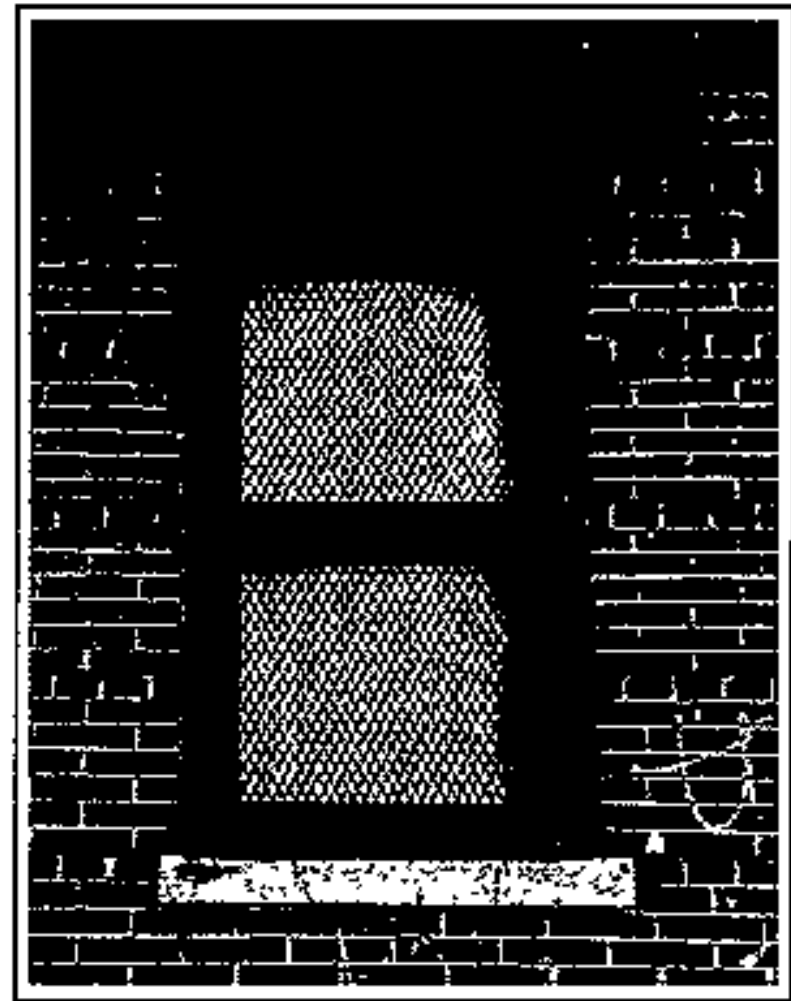

Some wealherizetion crews inctsily gecurity measuress on tirst-story wintows.

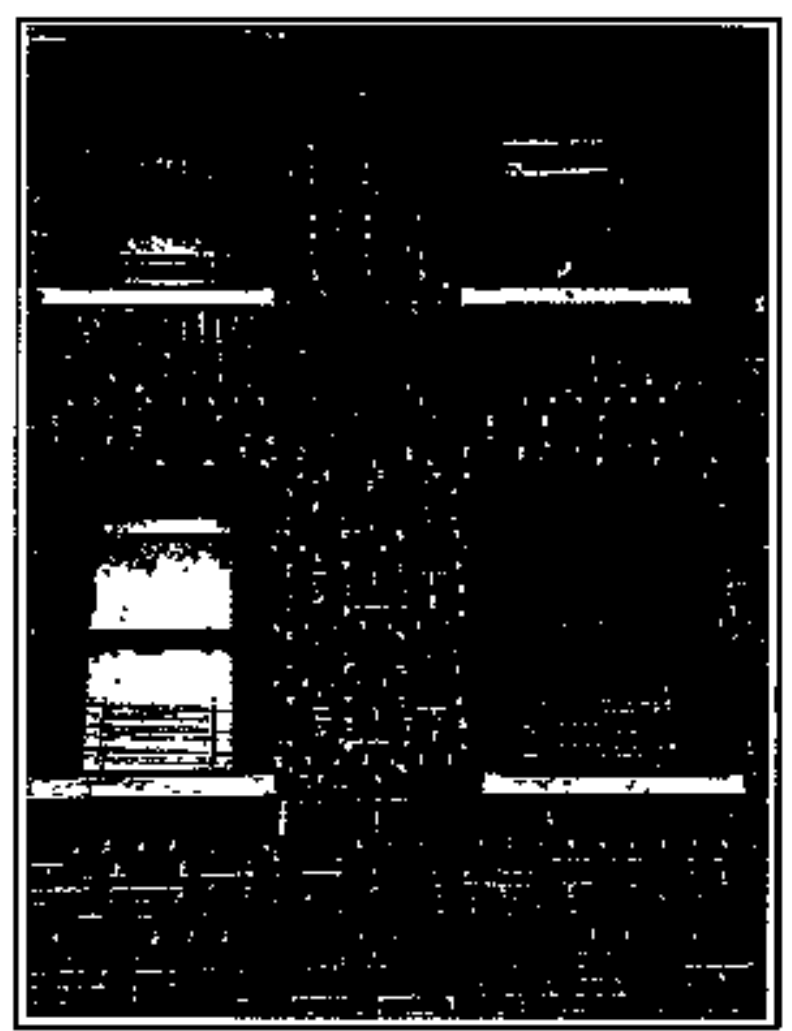

Higher lovel windows recelve grates to promote chlld safery. 
The value of nonenergy benefits is often difficult to quantify. For the purposes of the evaluation, selected nonenergy benefits were assigued a dollar value, but the methods used to estimate thefr value varied. Estimates of environmental benefits relied on a Siterature review and on information about the proportions of weatherized dwellings using various fuel types and the average savings of different fivels. Estimates of employment benefits combined a literature review with data on Program employment, the skill levels of workers, and managers' judgments concerning the job market for weatherization workers. Data on Weatherization Assistance Program expenditures for home repair were used to quantify the benefits associated with maintaining or enhancing property values and extending the lifetimes of dwellings. The monetary benefits of reducing the incidence of tires were guantified using insurance industry data. Estimates of reductions in arrearages were based on a literature review and data on payment histories collected on the dwellings included in the evaluation. For each benefit included in the estimate, we developed an average value per weatherized dwelling.

UItimately, the dollar yalue of nonenergy benefits resulting from the weatherization of single-family and small multifamily dwellings was estimated to be $\$ 976$. The following table gives a summary of the nonenergy benefits.

\begin{tabular}{|l|c|}
\hline \multicolumn{1}{|c|}{ Type of nonenergy impact } & $\begin{array}{c}\text { Value of the impa } \\
\text { per dwelling }\end{array}$ \\
\hline Increased property value & $\$ 126$ \\
\hline Reduced incidence of fire & $\$ 3$ \\
\hline Recuced anrearages & $\$ 32$ \\
\hline Federal taxes generated froms direct employment & $\$ 55$ \\
\hline Income generated from indirect enployment & $\$ 505$ \\
\hline Avoided costs of unemployment benefits & $\$ 82$ \\
\hline Environunentil exteralities & $\$ 172$ \\
\hline Total & $\$ 976$ \\
\hline
\end{tabular}




\section{HEATING SYSTEMS}

From left to rght: A boiler tóchniclan, a local weadreriza. tion ofilicial, and an ownir oelebrate tho racent Installation of an energyofficiant boiltar in a Iarge multifarnlly buikfitng in Brooklyn. Owners in New York and some olber states provide 25 percent or more of the cosi of the work, lhus leveragling scarce weralhesization funds.

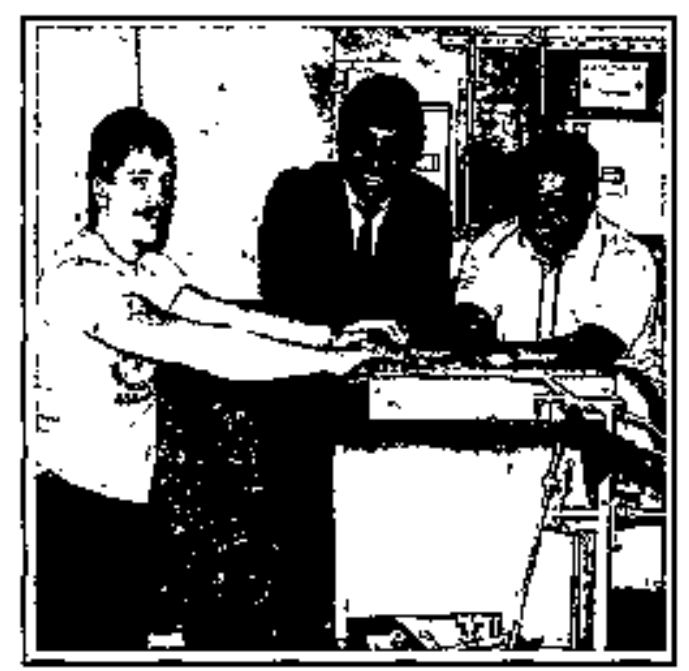

Mlodem mult-setback thermostals are costoffective meastures in many weetherization pose.

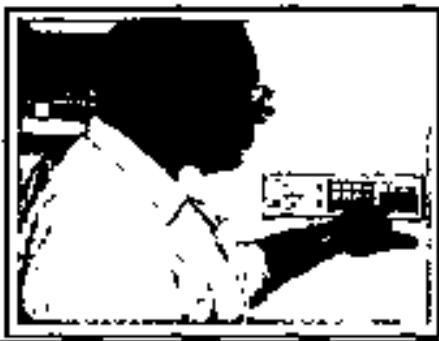

Kerogene heaters, like thls one stored in the basemont, consribitile to poor indoor air qualtty. Educalion work with weatherization cliants includes siem warrings aboul the hazards of these heatersand the impartance of geting rid of them erillely.
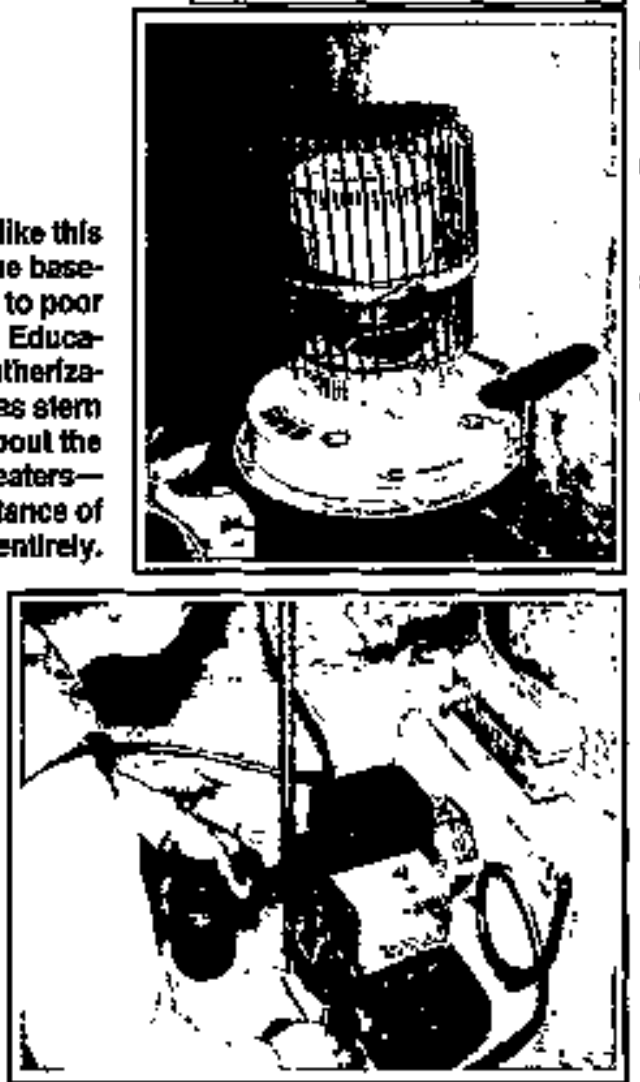

An ald boilar in a singte-family dwelling in Philadefphia has plenty of tife left in tit, but its burner was Inefilclent and unsafe. This new burner assembly will save about 14 parcent of the arkual fut oil bit.
Furnace resting for safery and efficiency has recently become a routine part of many weatherization operations, yet thene are still states which pay little attention to heating system work. Others do major wotk-when needed-ranging from switching to efficient oil burners to boiler replacement.
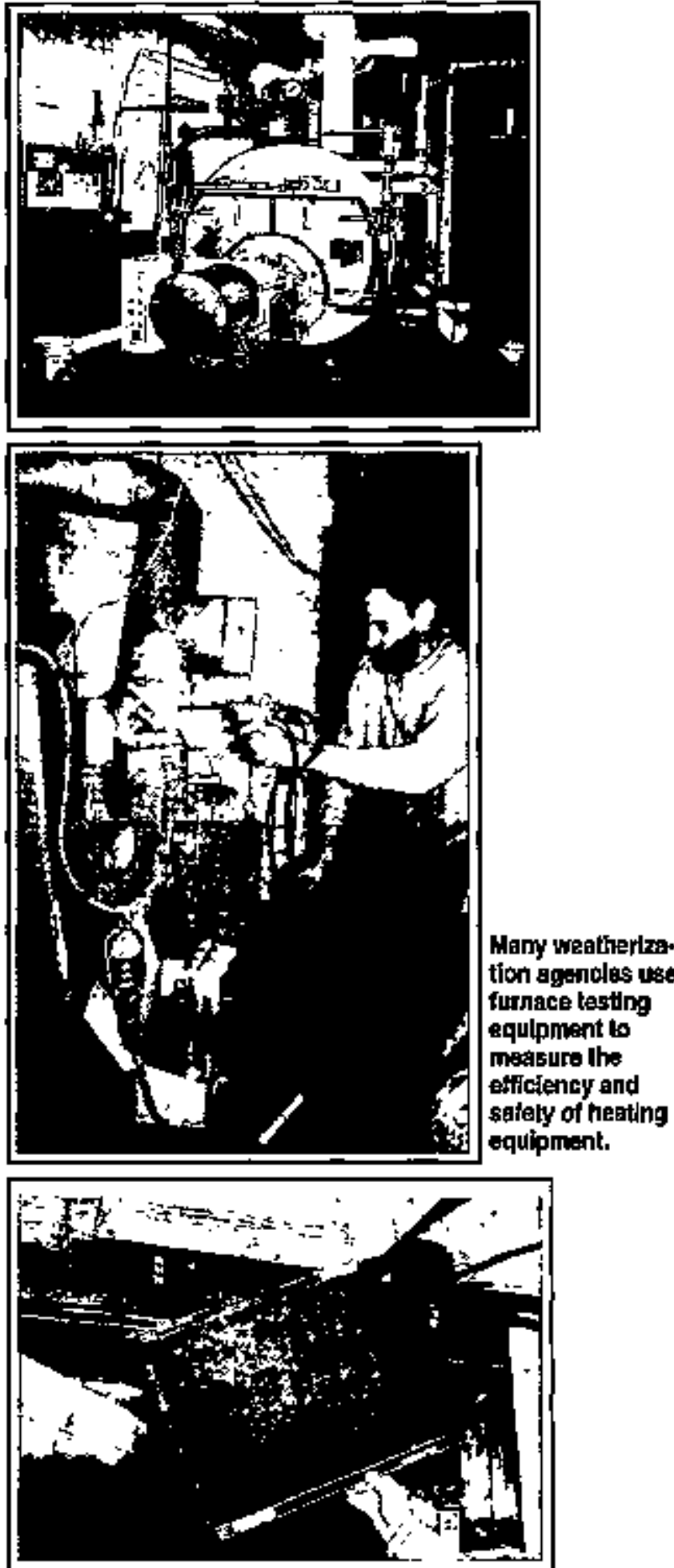

Filthy return gir filters, found frequenily in the weatheriza. tion program, are both unhealthiul and Inofflclent. Cleaning and tuning of fumsces, setting controls for etfictency, repilacing filters-and empowering clents to do the Job in the tulure-are routinely accomplished in moel watherization operations. 


\section{Cost Effectiveness}

Costeffectiveness is a measure of how well aprogram works. To assess the cost effectiveness of the Weatherization Assistance Progran, the market value of energy savings (and in some cases other benefits) was compared to the cost of installing the measures that produced them. Benefits and costs were discounted over the estimated life of the measures. Cost effectiveness was assessed only for single-family and small multifamily dwellings because estimates of prognan irnpacts were not available for large multifartily buildings, which comprised only 9 percent of the dwellings weatherized in 1989.

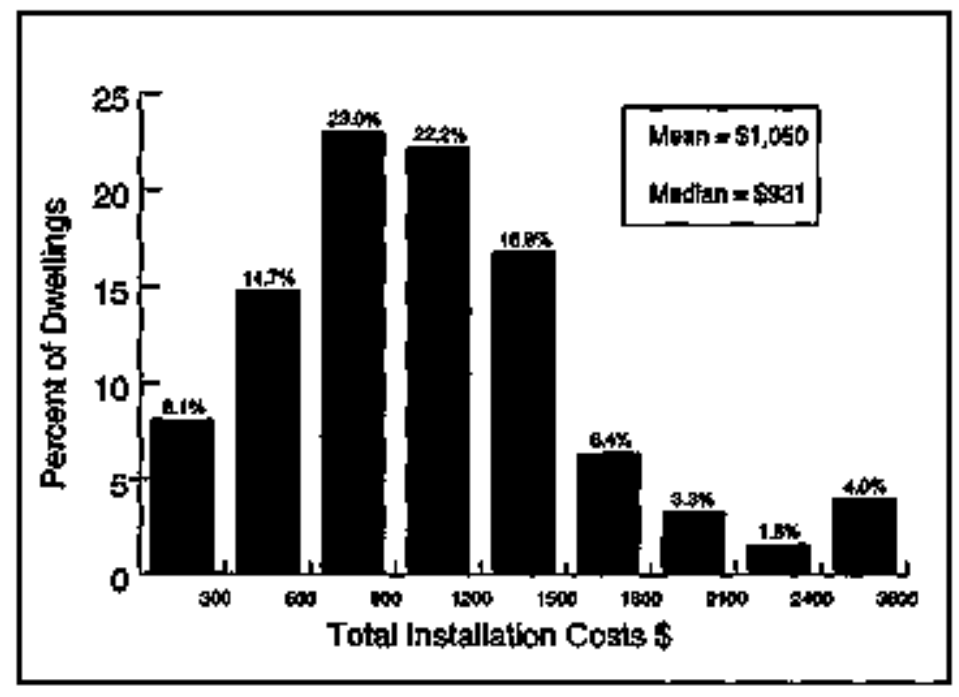

Installation Costs far Single-Famlty and Small Multifamily Dwellings Weatberixed in 1989.

\section{Program Costs}

DOE regulations in 1989 required (subject to certain exceptions) that the average of all costs not exceed $\$ 1,600$ per house and that at least 40 percent of this total be spent on materials that remain in the weatherized houses." When the weatherization work is supplemented by non-DOE funds, average costs may exceed $\$ 1,600$, andmaterials costs may represent less than 40 percent of the total.

To provide a picture of costs that is reasonably consistent regardless of the sources of funds used, costs were grouped under two broad categories: (1) installation costs (i.e., labor and materia)s assignable to particular houses) and (2) overhead and management costs. Overhead and management costs include costs directly related to justaliation but not readily assignable to particular houses (e.g., vehicles, travel time, and field supervision) and program management (e.g., intake, inspections, and general administration).

Installation costs for single-family and small multifamily dwellings weatherized in 1989 averaged \$1,050. For not quite balf (45 percent) of the dwellings, these costs fell within the $\$ 600$ to $\$ 1,200$ range. The chart shows the range of costs.

Because of variations in record-keeping, it proved difficult to specify overhead and management costs with the same degree of precision as installation costs. After approaching the problem from several parspectives, the evaluators settled on an average cost of $\$ 500$ per single-family and small multifamily dwelling nationwide.

The evaluation examined cost-effectiveness in detail from three perspectives:

- The installation perspective: the only benefit valued was net energy savings and the onty costs included were installation experditures;

- The program perspective: the only benefit valued was net energy savings, and costs included installation, management, and overivead costs; and

- The societal perspective: benefits included both net energy and nonenergy benefits, and costs included installation, management and overhead. 


\section{DOMESTIC HOT WATER}

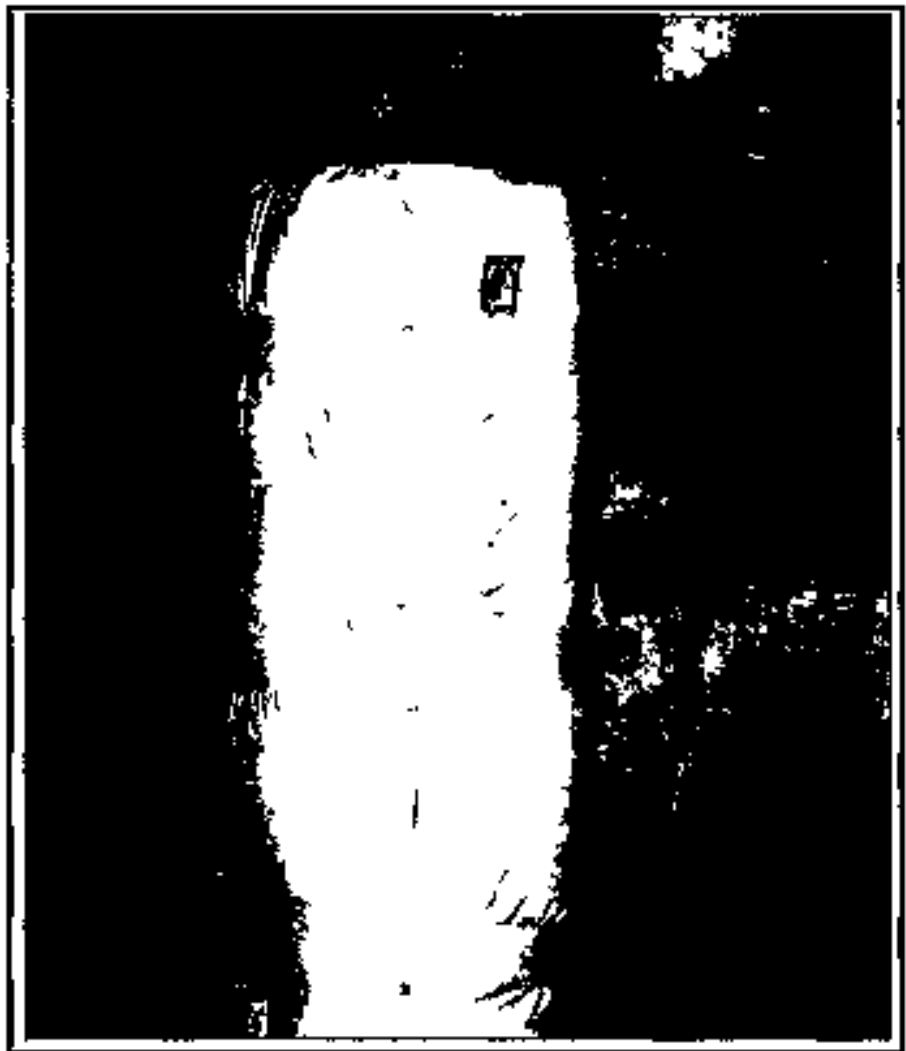

Conserving energy used to heat water is usually a cost-effective undertaking. Stopping leaks with minor plumbing repairs can result in substantial savings, as can installing low-flow devices like shower heads and faucet aerators. Most weatherization agencies report that the best results come from combining client education with good-quality shower heads. Similarily, the installation of tank insulation by weatherization agencies is frequently accompanied by turning down the tiermostat on the water heater, an action that is often taken in conjunction with client education to promote sustained energy savings. Many agencies also install pipe instlation a few feet on the cold water inlet side (to prevent thermosiphoning during the standby cycle) and 10 feet or more on the hot water side.

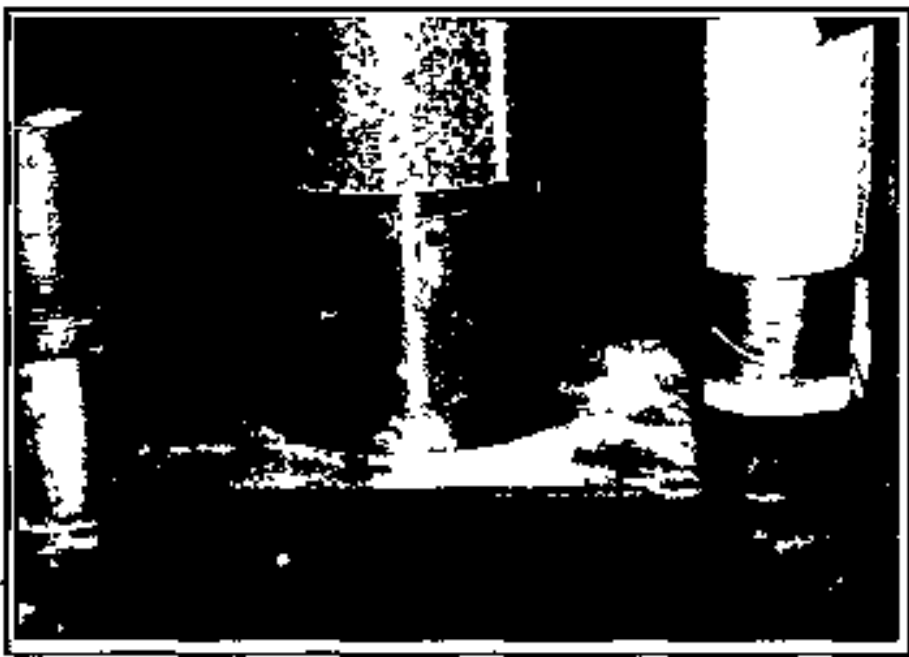

A flue damper installed on this domestic hot water hoater limits hest loss to the chitminey during the of cycle.

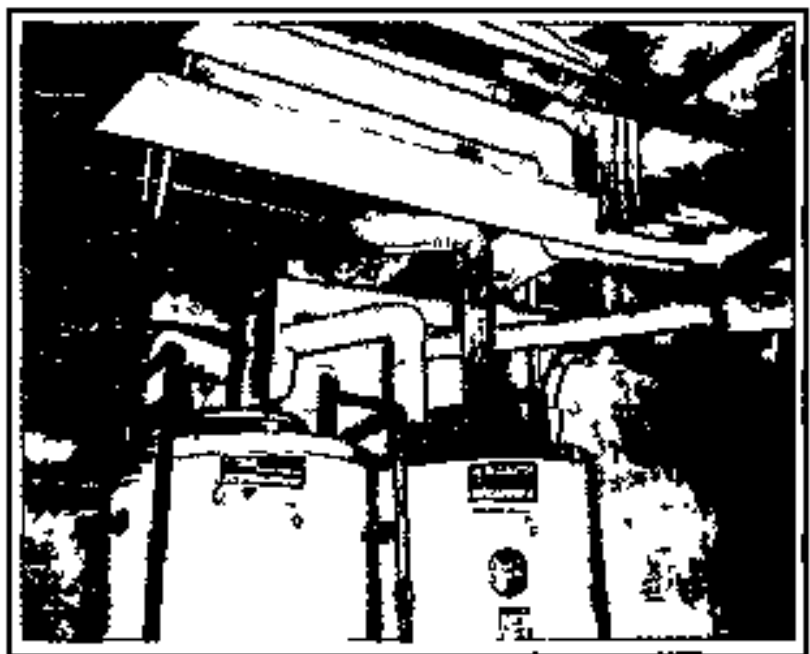

The weatherization orew which instilated tho tank and pipes entering and exiting from thls hot water healer did an excellent job. 


\section{Performance by Climate Region}

Performance indicators for the national Program mask a great deal of diversity. This diversity sprisigs from regional differences and associated housing types and needs and from varying practices of weatherization agencies. The following sections present the evaluation results by region. Characteristics of the housing stock and local agencies account for much of the regiongl variation in weatherization practices and measures installed. These, in turn, provide important background for understanding regional variations in weatherization costs, energy savings, and cost-effectiveness.

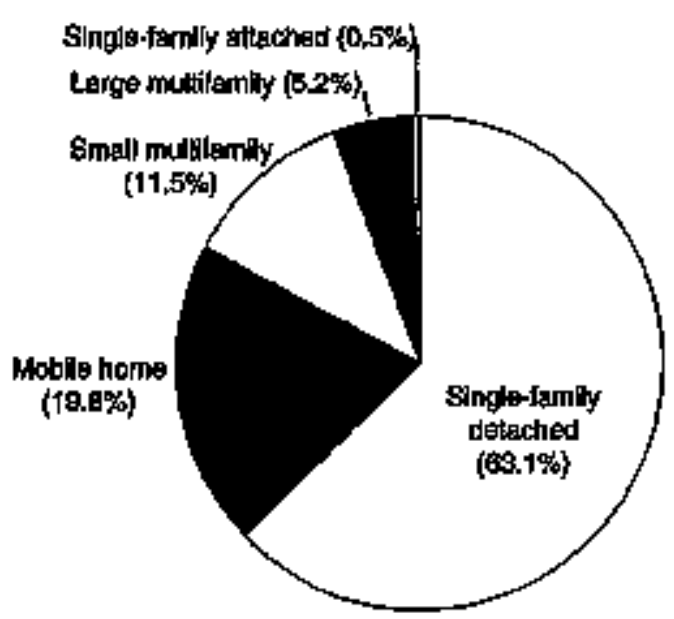

Types of Dwellngps Weatherized in 1989 in the Cold Refion.

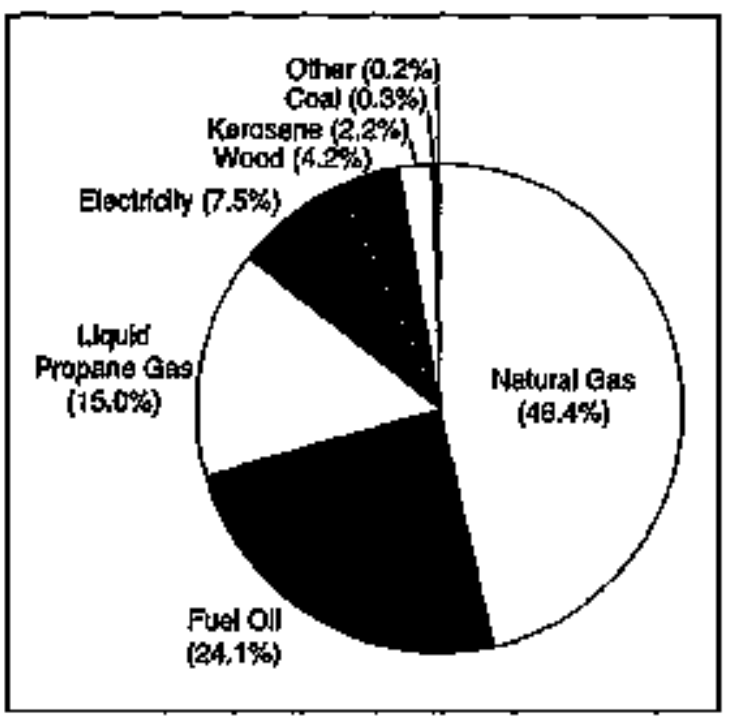

Types of Heating Fueks in Single-Family and Small Malitamily Dwellings Weatherized in 1909 in the Cold Region.
As a whole, the Program is most cost-effective in the cold and moderate climate regions of the country, where prograns are concentrated. In the hot region, where agencies are smallest and the low-income housing is most dilapidated, the Program saves less energy per dollar expended.

\section{The Cold Climate Region}

The cold region contains 11 states with an average of 7,444 heating degree days. In 1989, approximately 150 local agencies in this region weatherized more than 40,000 dwellings (18 percent of the total weatherized population).

Benefit/cost ratios are greater in this region than in any other region, ranging from 1.3 to 2.9 depending upon the "perspective." This region also achieves the highest savings of any region, based on the SingleFamily Study. For natural ges consumption, the first-year net savings of 235 cf representa 25 percent reduction in the gas used for space heating and an 18 percent reduction in total gas usage. Net electricity savings total 2,686 $\mathrm{kWh}$ for the first year, which is a 42 percent reduction in electricity use for heating and a 14 percent reduction in total electricity usage. Total costs average $\$ 1,576$ per household, higher than the national average.

The majority of weatherized homes in the cold region are singlefamily detached (63 percent). Findings from the Single-Family Study show that this region has the oldest housing stock (averaging 45 years) and weatherizes dwellings that are on average larger than the other two regions ( 1,181 square feet). The primary heating fuel, as with all regions, is natural gas. This region, however, has a significantly higher portion of the population using fivel oil. A central heating system was found in 83 percent of the dwellings, the largest proportion of any region, and supplemental heating fiels are less common (24 percent of the weatherized single-family population). Two-thirds of these dwellings are owner-occupied, and they have the largest average number of occupants of any region.

The cold region uses the most rigorous methods for both client and weatherization measures selection. Integrated audits for measures selection are nsed over three times more frequently than the national average. Theuse of advanced diagnostic techniques ishigher than in any other region. The Single-Family Study shows that blower door tests are performed almost twice as frequently as the national average. The cold climate zone has high installation rates for insulation, water heating, and space heating measures. In contrast, the cold region has relatively low installation rates for structural measures and windows and doors. 


\section{DOORS AND WINDOWS}

Although most dwellings require air sealing, insulation, turnace retrofits, and at least minor repair work, exactly which tactics to employ is a decision that depends on the circumstances of the dwelling, the funding of the agency, and the know-how of the auditor and crews. This evaluation, plus testimony from experienced practitioners in the field, has shown that ccokbook procedures employed in the early days of the Programweatherstripping, caulking, and storm windows-were only marginally effective. Audits using advanced diagnostics direct crews to the real problems in a dwelling and usually result in more cost-effective work.

Window and door repair is a necessary part of most weatherization operations, but many agencies in the moderate and cold cliriate areas have abandoned the practice of routinely installing storm windows and exterior doors because they have found these measures do not save as wuch as many other less costly conservation measures. In less severe climate areas, stom windows and exterior doors stil] play a large role in weatherization operations, although this evaluation and others have shown that other measures are usually more effective and less costly.

Afthough this stom windor is gill functional, mlssing window trim end a rolten sill plate here done sulastantial damage. The sash welght ls vislble Irom the autaide of this dwelling.
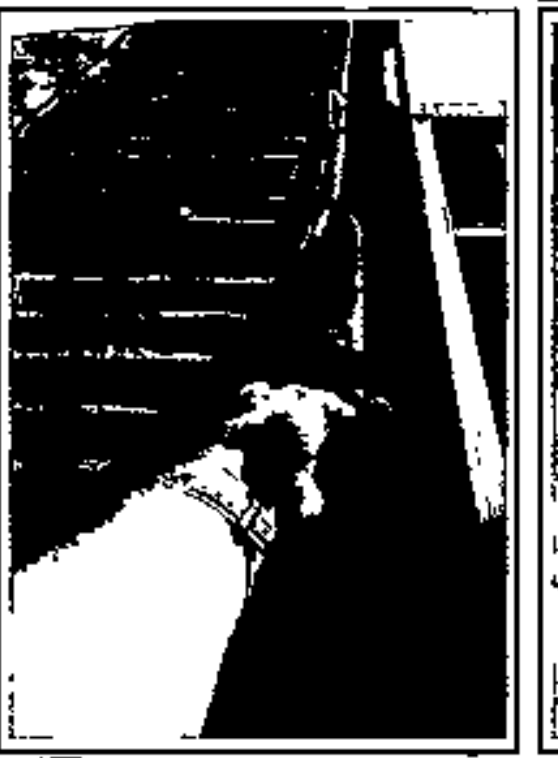

A naw lock set ls only marglnaity cost effective as a weatherizelion measure (ul can ald in air sealing), best elnce it stuppiles 8 measure of securthy, this repaitr can be the most important one for a clent, Spmetimes a new doar performs a simliar efecurtly funcilon.
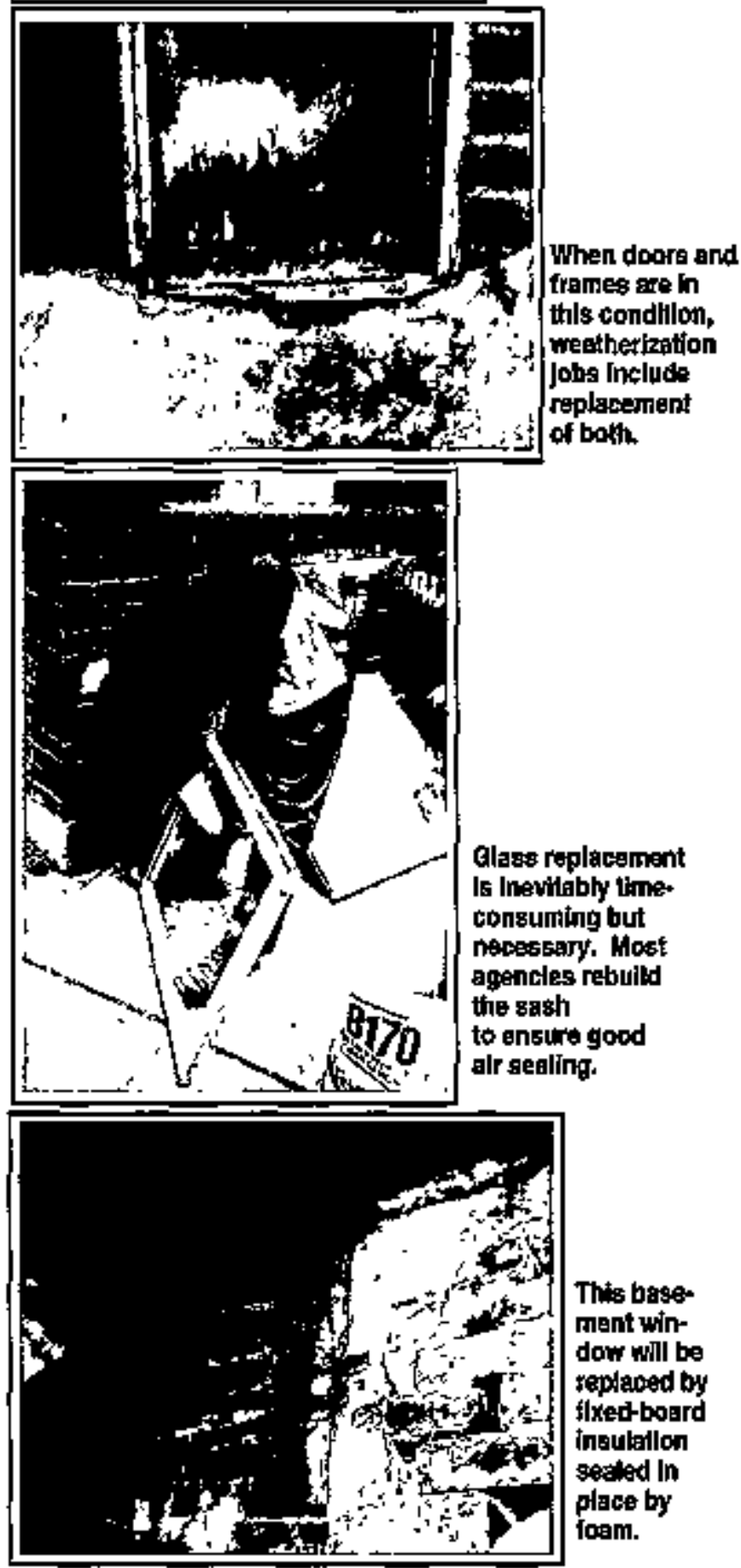

This base ment window will be seplaced by flxed-board insulation sezied In piace by foam. 


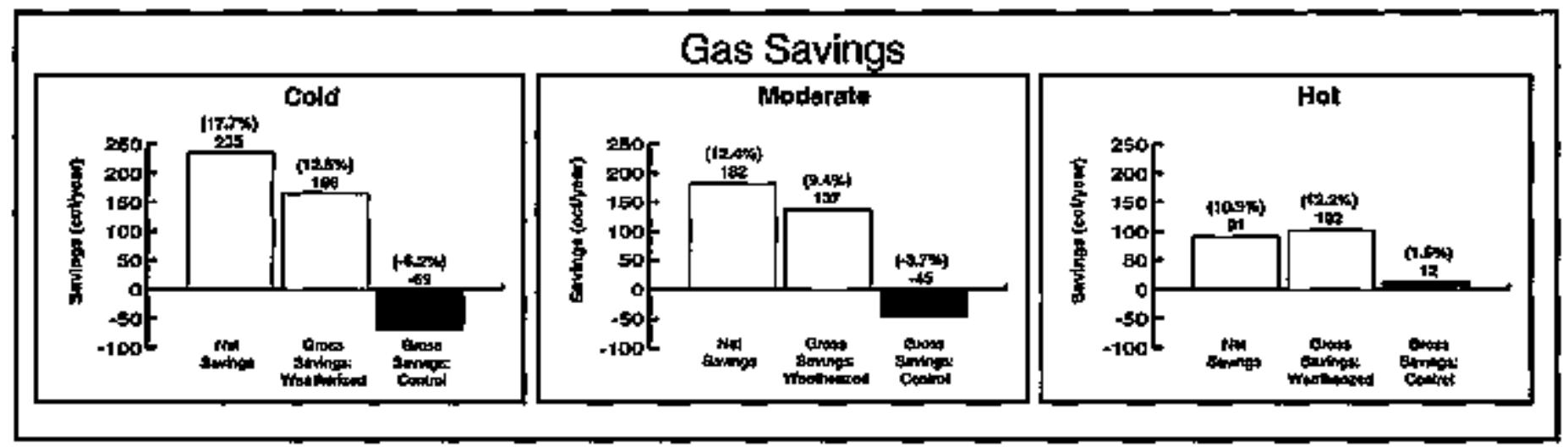

Gas Savings by Climate Regiont.

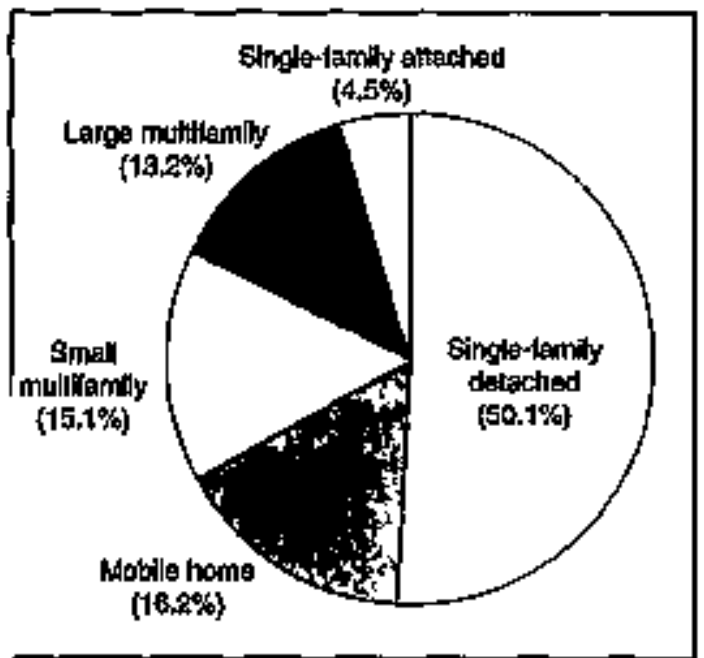

Types of Dwellings Weatherized in 1989 in the Moderate Region.

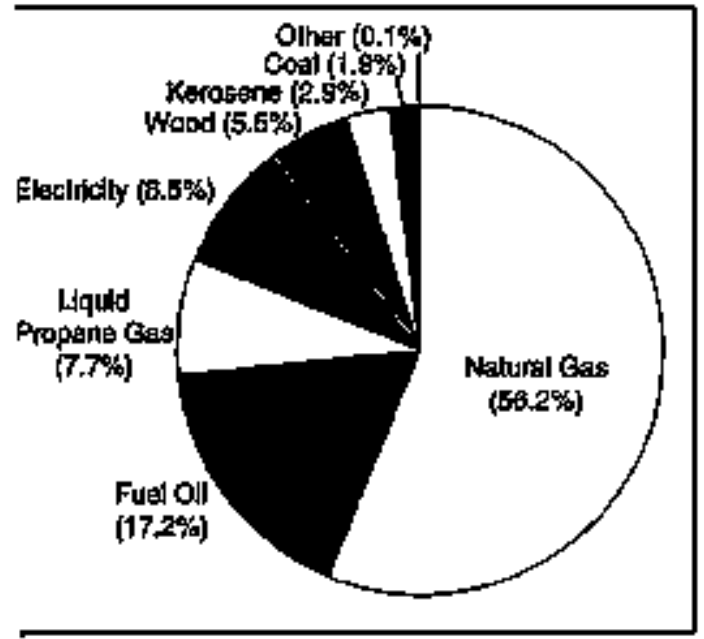

lypts of Heating Fuels in Single-Family and imall Multifamily Dwellings Weatherized in 989 in the Moderate Region.

\section{The Moderate Climate Region}

The moderate region consists of Washington, D.C., and 24 states, including the northern balf of California. The region has an average of 5,906 heating degree days. In 1989, this region contained nearly 570 local agencies that weatherized more than 140,000 dwellings ( 64 percent of the total weatherized population).

Benefit/cost ratios are substantial in the moderate region, ranging from 1.2 to 2.7 depending upon the "perspective." This region also achieves higher than average savings, based on the Single-Family Study. For natural gas consumption, the first year get savings of 182 ccf represents an 18 percent reduction in gas used forheating and a 12 percentreduction in total gas usage. Netelectricity savings total 2,479 $\mathrm{kWh}$ for the first year, which is a 44 percent reduction in electricity use for heating and a 15 percent reduction in total electricity use. Total costs average $\$ 1,580$ per household, essentially the same as dife cold climate region investment level.

Just over half of the weatherized hornes in the moderate region are singlefamily detached dwellings. This climate zone also contains almost 88 percent of all Iarge multifamily dwellings weathertzed. Findings from the SingleFanily Study show that this region has dwellings that are older than the national average ( 44 years on average for the region). The use of natural gas is predominant in this region, with more than 56 percent of the weatherized dwellings (in the Single-Family Study) using this type of fuel. This region contains the smallest population of owner-occupied dwellings (59 percent of the single-family and small multifamily dwellings).

In the moderate region, only 15 percent of the clients were selected on the basis of estimated energy use or savings, as compared to 43 percent in the cold region. Similarly, integrated audits were used in only 5 percent of the dwellings, compared to 28 percent in the cold region. However, this region excelled in the use of heating efficiency tests as a diagnostic tool and later for quality controi. In the moderate region, all of the major types of weatherization measures were installed at higher than national rates. 


\section{MOBILE HOME MEASURES}

Many mobile homes have inconspicious air leakage paths that can be clearly identified with blower doors, yet at the time of the Single-Farnily Study, few agencies in the hot region used blower doors. Successful weatherization work focuses on closing leaks at the bottom of the conditioned envelope. especially around the duct system. A recent Indiana study showed 32 percent savings in mobile homes resulted from blower-doof guided infiltration reduction and blowing cellulose insulation in the belly board. A recent evaluation of the Vermont Weatherization Assistance Program provided evidence of substantial electricity savings from air sealing the water heater compartment of mobile homes, even when the electric water heater had already been jacketed.

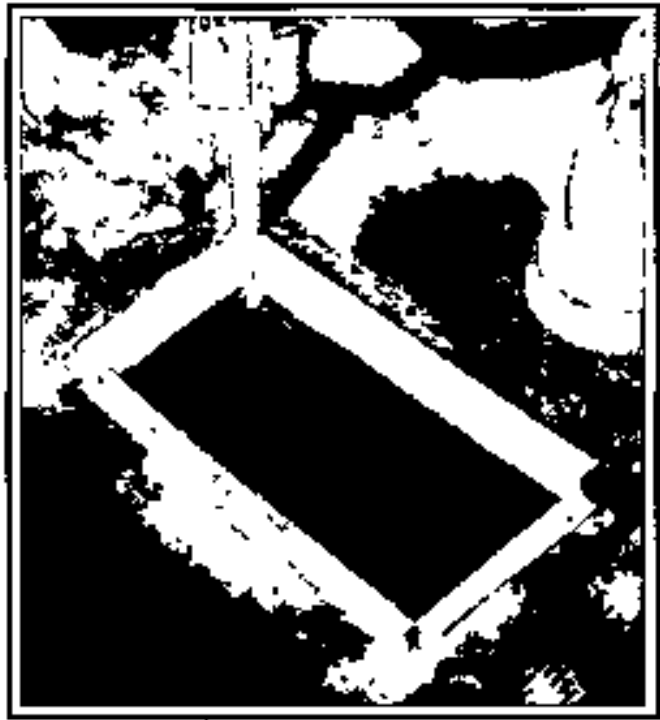

The interface between the riser in a supply duct and the floor of a moblle hame is frequently found to be a source of air leaks, bolh when the furnace tan is on and when it is not. Here a technician in lindiana uses a technlque hls ageney developed to extiover a tight, iffolong seal.

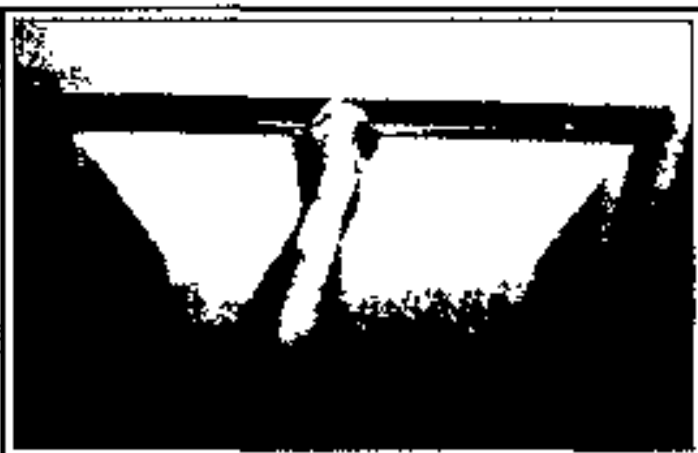

Seafing the opening to the evaporative cooler dup. ing windar months is routinety acoompulisted by weat'ierization technlclans in Arlzona, who find thls a very cost-efiective weathertzallon tactic wilh both mobile bomes and sito-suilt suructures. Solar screens also result in significeant savinga in thts semidesert cirmate.

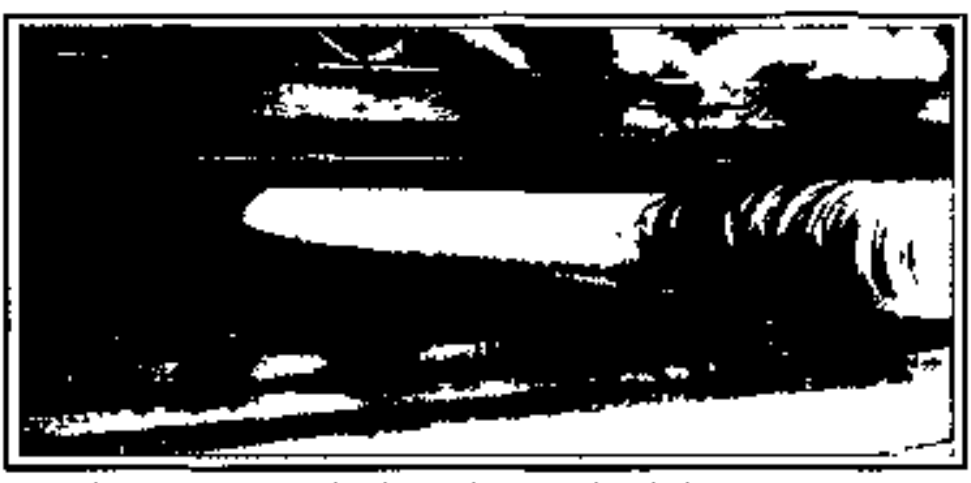

A 30-foot-long plastle pipe is used to blow Insuladion botween the bely board and the tloor of a mokile home. 


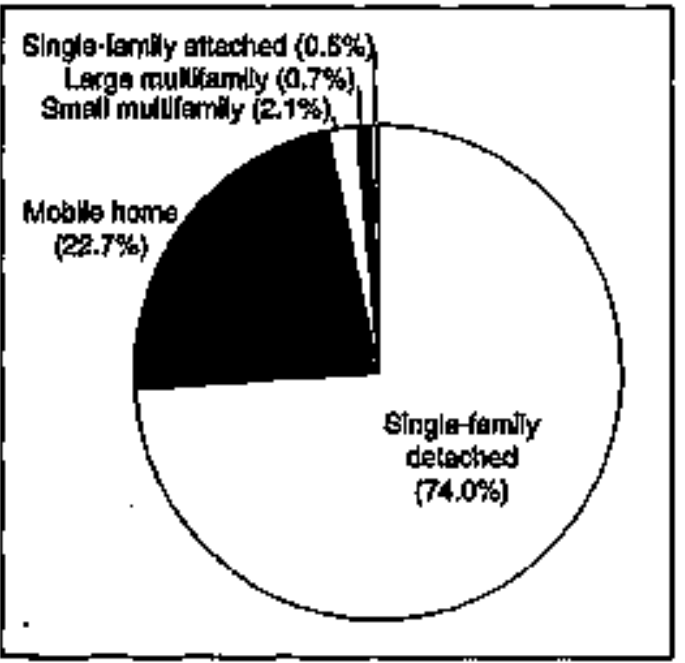

Types of Dwelliges Weatherized in 1989 in the Eot Reglon.

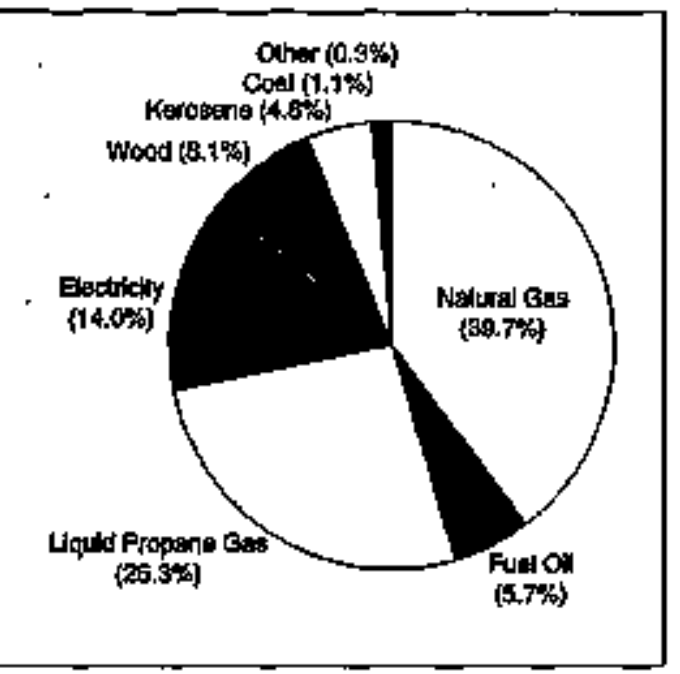

Types of Heating Euels in Single-Eanily and Small Mralt:family Dwellings Weatherized in 1989 in the Hot Region.

\section{The Hot Climate Region}

The hot climate region consists of 14 states, including the southern half of California, and has an average of 2,527 heating degree days. In 1989 , this region contained nearly 380 local agencies which served 40,000 dwellings (18 percent of the total weatherized population).

Benefit/cost ratios for the hot climate region range from 0.4 to 1.6 depending on the "perspective." This region saves less than the national average, based on the Single-Family Study.For gas-beated homes, the first year net savings of 91 cef represents a reduction of 15 percent of total gas used for heating and an 11 reduction in total gas usage. Net electricity savings total $595 \mathrm{kWh}$ the first year, which is a 16 percent reduction in the electricity use for heating, or a 5 percent reduction in total electricity use. Total costs average was $\$ 1,469$ per household, the lowest in the nation.

Nearly three-quarters of the weatherized homes in the hot region are single-family detached homes. This region also has the largest population of mobile hories ( 23 percent of weathenzed dwellings). Findings from the Single-Family Study show that this region has by far the youngest and snuallest dwellings (averaging 33 years and 987 square feet, respectively). Liquid propane gas is used as a primary heating fiel approximately twice as often as the ntitional weighted average, and central heating systems are present in only one-quarter of the homes weatherized in 1989. The hot region also has the largest proportion of elderly occupants (62 percent higher than the national average) and handicapped occupants ( 67 percent higher than the national average).

In this region, measures are usuatly selected from priority lists rather than through the use of an energy audit, and sophisticated diagnostics are rarely used. Space-heating measures were installed in only 2 percent of the dwellings in this region, according to the Single-Fanily \$tudy. Inșulation and air leakage control measures were also installed less frequently than the national average. In contrast, the hot region installed more window and door measures and spent 28 percent more than the national average on stnuctural meastres, reflecting the more dilapidated condition of lowincome housing in this region.

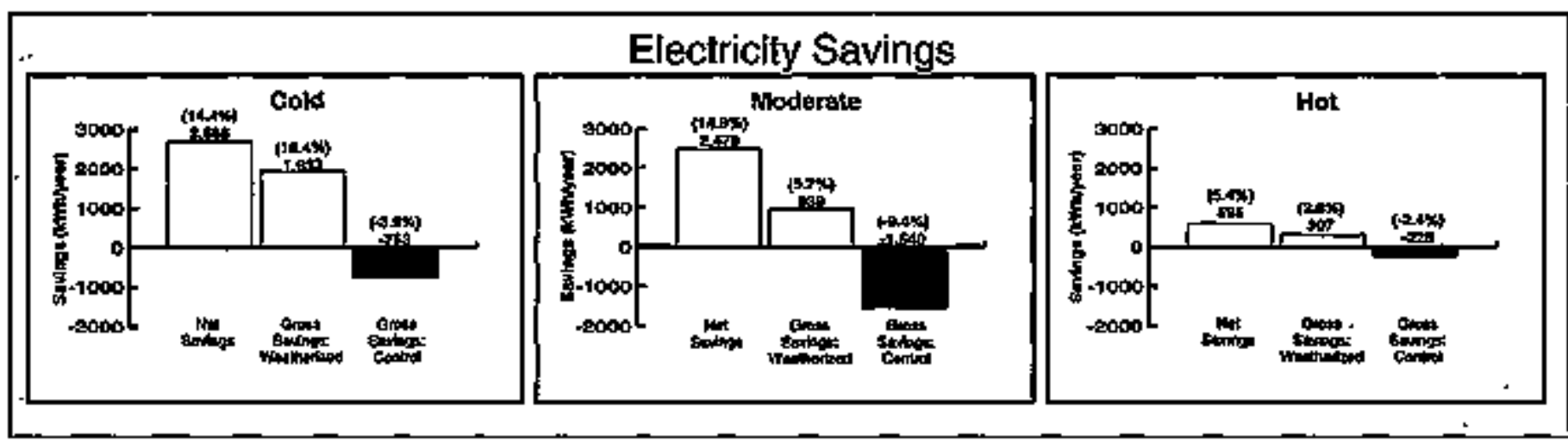

Electricity Sayings by Climate Region. 


\section{LARGE MULTIFAMILY MEASURES}

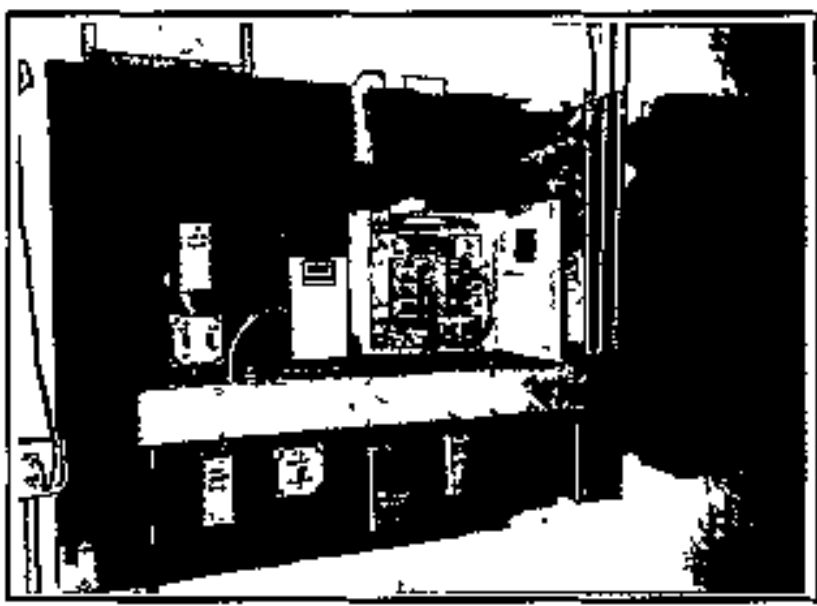

Elettronio controts pan tontroute enormousiy lo santings. This device varles bolker fiving Inm in response to outside air temperature and retum condensele temperature to enstute even heattmg.

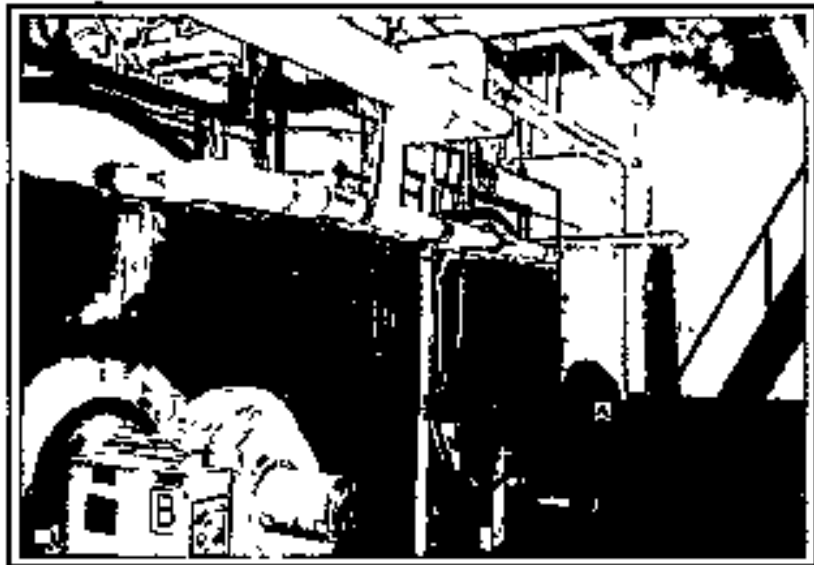

This larte complex in the Bronx with 961 untis now has a paik of new energy-efficient 200 horsepower boliers and a newily designed diskrlbution control system.

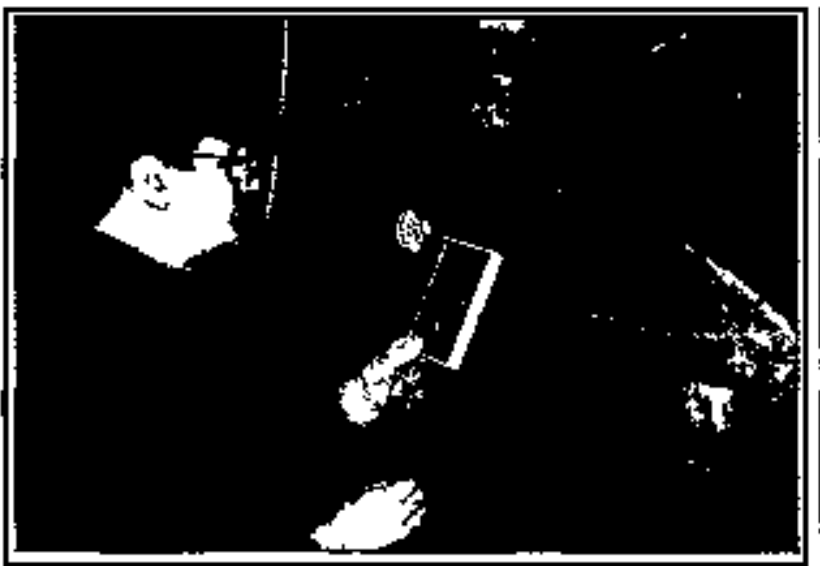

Thls manometry is a pracision instrument that can be usad as both a draft genge (stionn with a large bojler) and as a tobl th explore dir leakiness between zones ani slackeffect intituraton.

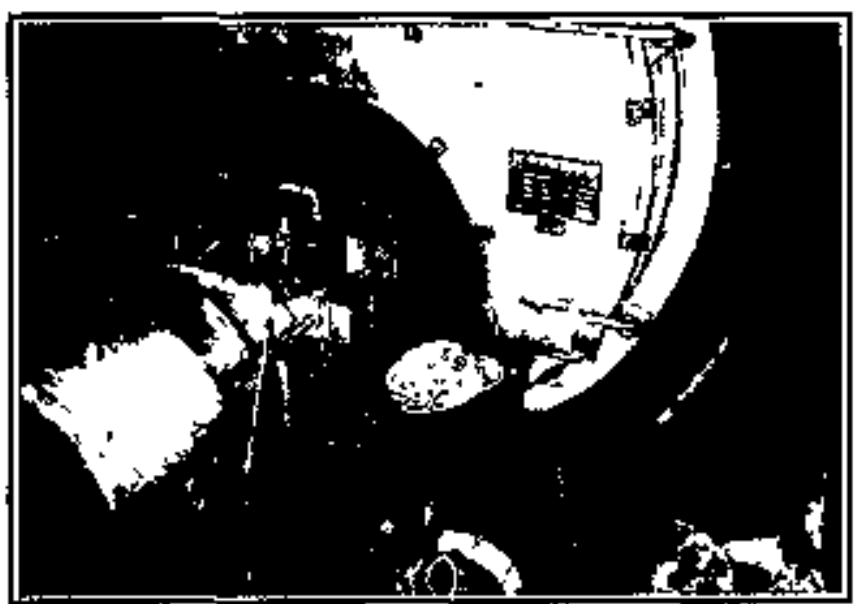

Thls complex in Brooktya which was proviously served by four, 40 horsepower gas-4ired bollars is now served by a more effictent single 125 horsepower boiler fired with :6 tuel ot:

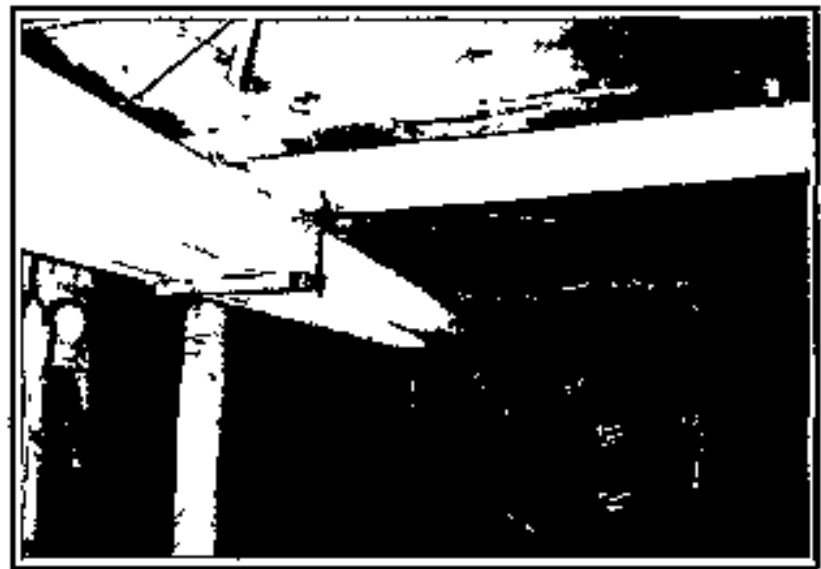

Nenty insulated pipes traverse the boiler rapm on the way to aportmenis upstalrs. The superinlendent has added the air sealing job and iresh pa'nt.

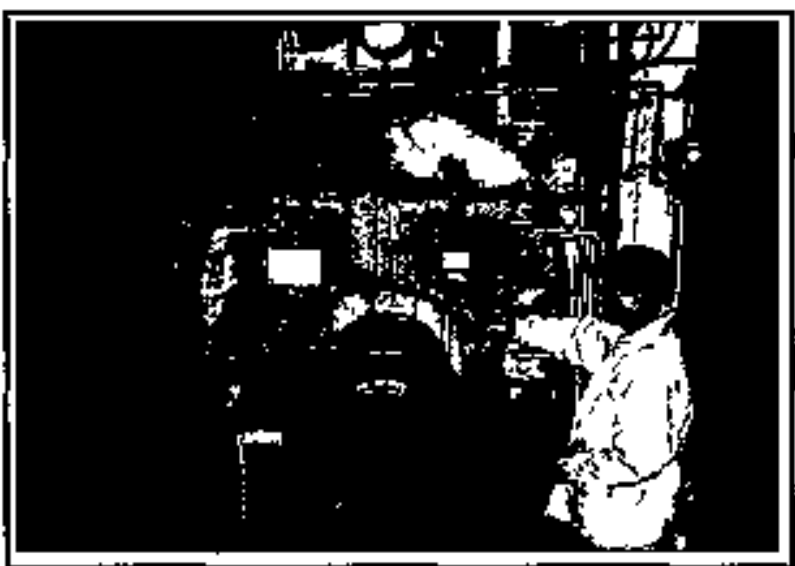

Otd boilers such as this one have substantial radiational hout lossas, here boing measured with a spat radformoter. 


\section{FOUNDATIONS FOR CHANGE}

The fundamental pucpose of the National Weatherization Evaluation is to analyze the performance to date and identify promising opportunities for the future. Knowing which measures tend to produce good savings-and which don't-is critical in providing useful feedback to weatherization practitioners.

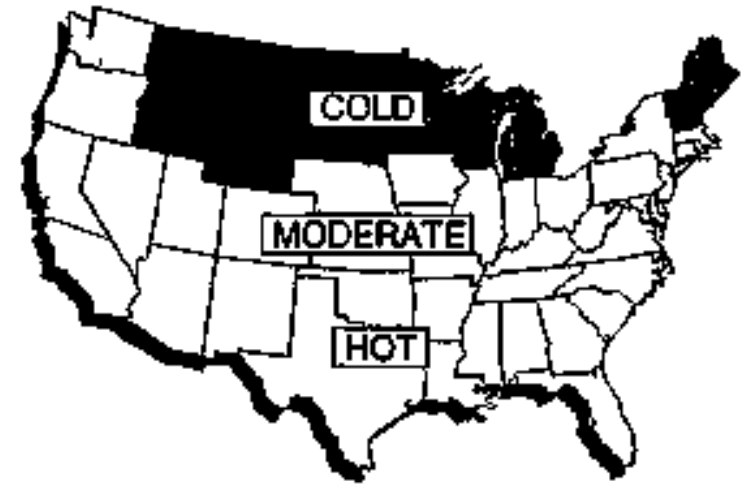

Gas Savings Electricity Savings

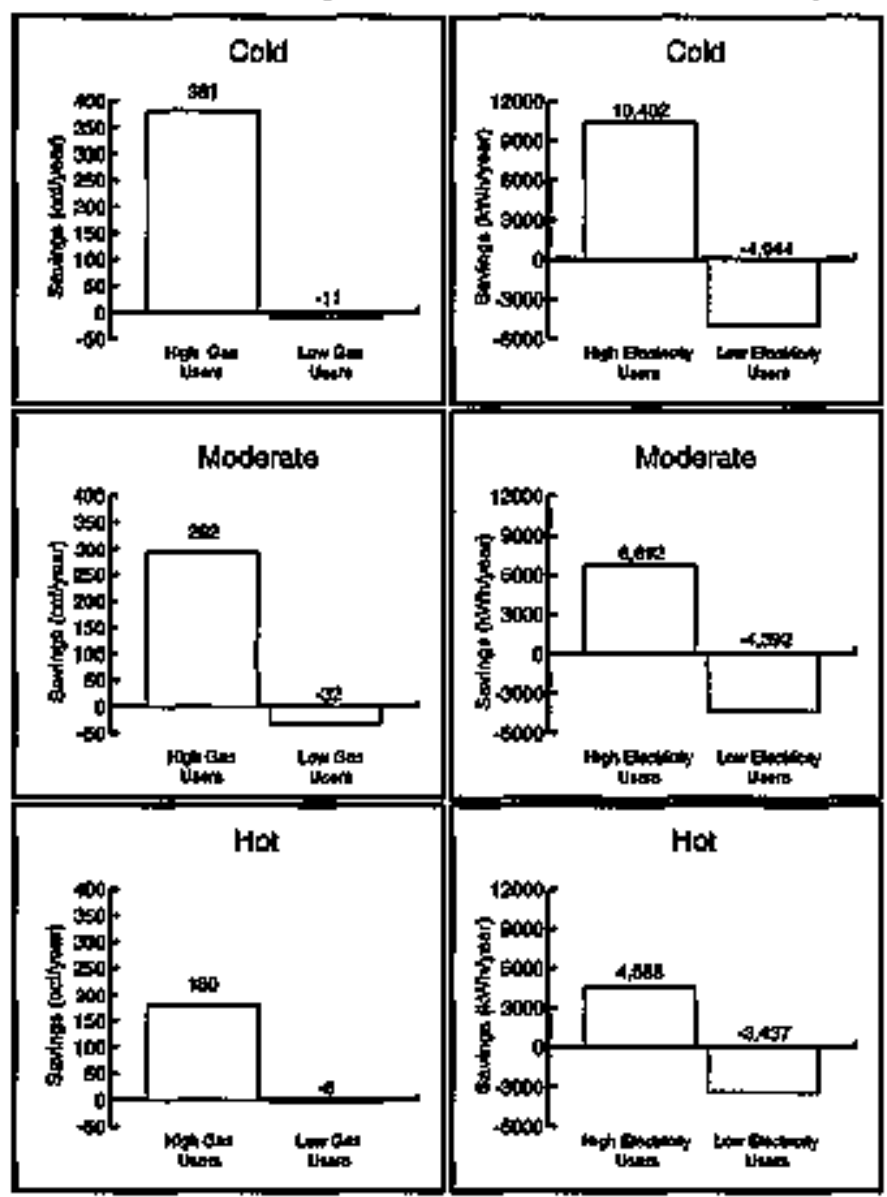

Energy Saviags Is Greatest in Hames That Use the Most Rnergy.

\section{A. Savings Associated with Specific Pro- gram Practices}

The study found that the following practices are associated with higher-than-average savings:

- Weatherizing high energy users. Within each climate region, weatherizing high energy users is associated with high energy savings. High energy use usually points to specific weaknesses in the dweiling's envelope or heating system. Solving such problems usually produces highly cost-effective savings. This is illustrated by the figure which shows dramatic differences between savings achieved by the weatherizationjobs accomplished on the highest guartile of gas and electricity users versus the lowest quartile.

- Using an integrated andit of the heatingsystem and envelope. Integrated audits help pinpoint problems and guide weatherization work towards what makes a difference-and away from what doesn' $t$. They consider both envelope and heating and cooling system needs, and provide savings-to-investment ratios for individual measures. Although integrated audits were just emerging in 1989, several of the high-performing agencies identified in the Single-Family Study used them.

- Curing distribution system problems. Air leak. age from distribution systems can cause serious health and safety problems, as well as affect energy consumption. Curing them is correlated with higher-than-normal savings.

- Replacing furnaces. This measure is not ofly positively correlated with higher-than-average savings, but also frequently solves safety and health prob]ems. Since this is usually a high-cost measure, its cost-effectiveness-considered as only an energy conservation measure-is not always high. On the other hand, it often is a vital health and safecy meastre, since removing a furnace with a broken heat exchanger can improve indoor air quality and save lives.

- Installing attfcinsulation. This evaluation clearly showed that the installation of insulation in attics never before insulated is particularly cost-effective. 
Advanced energy audits consider both envelope and heating and cooling system needs, and produce estimated entrgy savings, stavings-to-investment ratios, and a list of the quantities of materials necessary to complete weatherization. Another distinguishing feanure of advanced energy andits is their use of billing histories to gauge the relative opportunities for savings and to reconcile engineering estimates of consumption and savings.

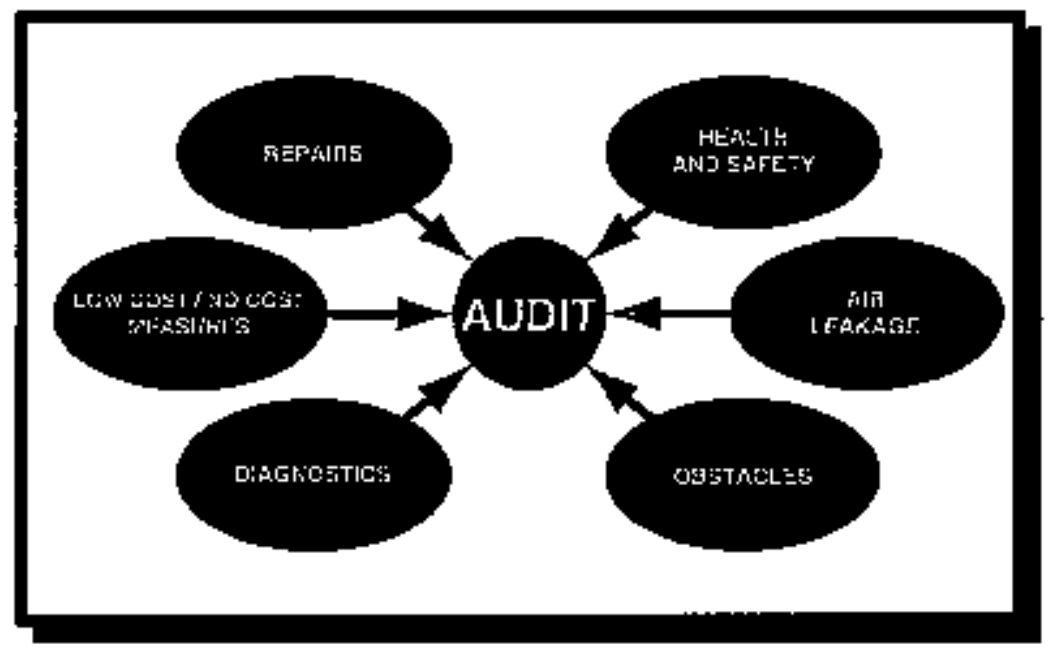

Advanced energy audits can use a variety of data provided by the auditor and by dlagnostic measurements (air leakage and equipment efficiencles).
The National Energy AudiT (NEAT) is a sophisticated computer-based audit developed specifically for DOE's Weatherization Assistance Program. NEAT uses a variety of data (on the building and its heating and cooling systems) to produce a prioritized list of cost-effective measures, customized for an individual house. It is advanced, yet user friendly.

This audit is one option for states. Some states have developed comparable atxdits tailored to their local needs.

\section{SIMPLIFIED OPERATION DIAGRAM OF NEAT}

At the "start," users can:

1. enter building data,

2. customize seup of NEAT, and

3. recall previous building data.

At the "end," users have the option of entering and adjusting resu[ts with billing data.

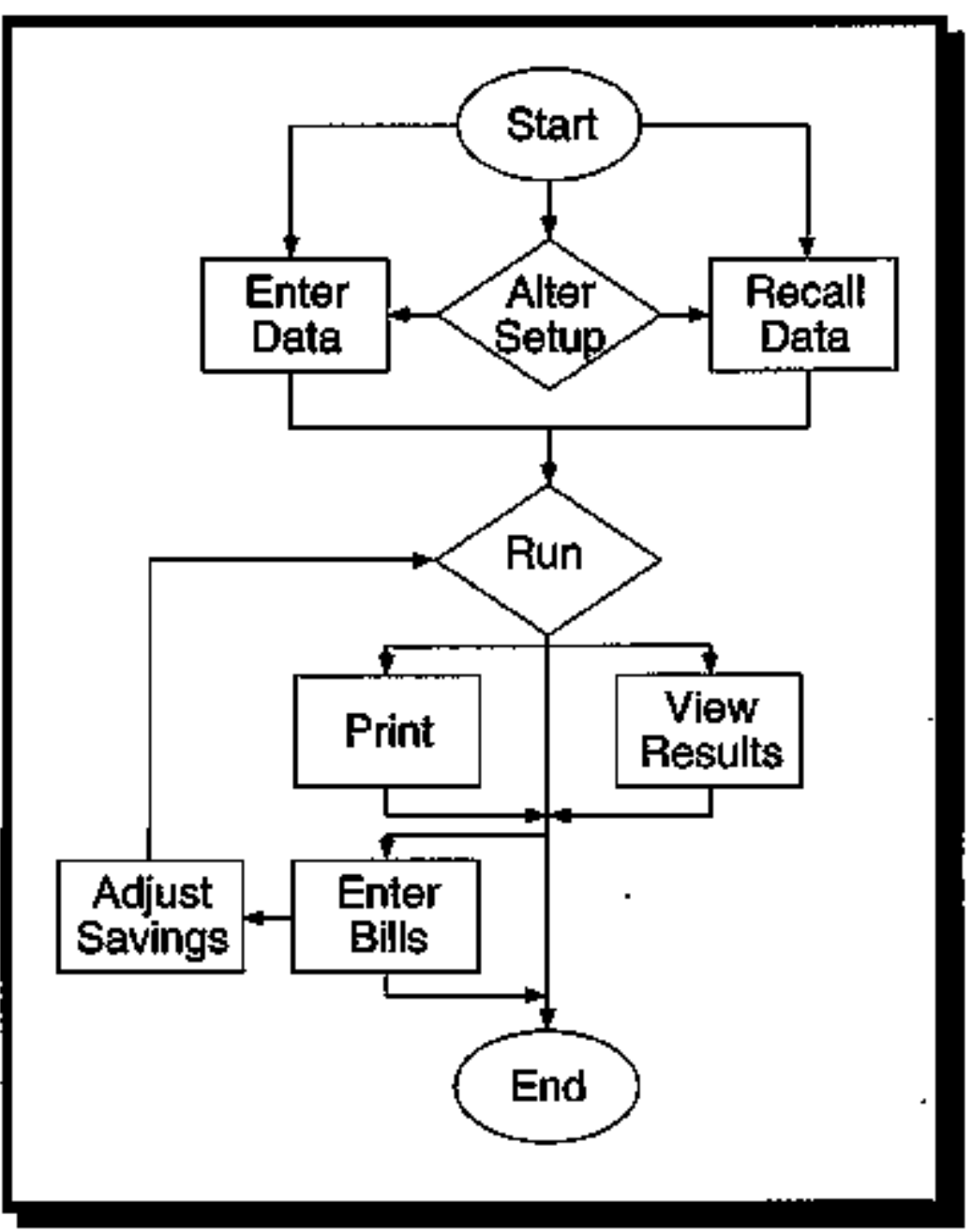




\section{A. Savings Associated with Specific Program Practices (cont.)}

-Installing wall insulation. During the time of the evaluation, only a few agencies had begun using the high-density installation technique (which accomplishes air sealing and insulation with a single operation). However, weatherization jobs that included high-density wall insulation showed even greater savings than those that used the older technique.

- Installing floor insulation. The presence of this weatherization measure was also positively correlated with greater-than-average overall savings. It is especially effective when the floors insulated are over vented crawl spaces.

- Installing water heater measures. These measures include tank and pipe insulation as well as turning down themostats. The result is a diminution of base-load consumption of natural gas measurable through analysis of billing data.

Investments in storm windows were not generally associated with measurable energy savings. The payofif expected from another measure-blowerdoor-assisted air sealing-also was not discemible in the Single-Fantily Study. This finding is attributed to the fact that blower doors were just being introduced into local agency procedures in 1989 , when only 18 percent of completed dwellings received blower-door-assisted sealing. Today, agencies offer training in their use. In fact, low-income weatherization agencies have become leaders in the application of blower doors and are generally convinced they save energy.

\section{B. Promising Management Practices}

A handful of other practices erriployed by many weatherization agencies clearly make sense, but their impact could not be quantified through this evaluation. These include client education and resource leveraging. Some agencies are very active in providing client education and report good success in forming partnerships in which recipients of weatherization services participate in a number of concrete conservation activities in their homes.

Leveraging from utilities to accomplish the ends of demand-side management on the one hand and cost-saving conservation services for low-income farnilies on the other is becoming an increasingly important opportunity for enhancing weatherization. Utility partinerships are emerging across the country. Some agencies, for instance, provide electricity conservation services in conjunction with weatherization. These routinely involve removing inefficient incandescent kighting fixtures and replacing them with compact fluorescent Iighting, and sometimes replacing inefficient refrigerators with efficient ones. Other utility partmerships have enabled capital-intensive investments such as energy-efficient replacement fumaces that might otherwise not be possible.

Stil] problematic for many local agencies is the extremely poor condition of many dwellings. The Program will be stronger when adequate housing rehabilitation funding allows local agencies to provide needed repairs and devote a larger share of their DOE funds to energy-efficiency improvements. 


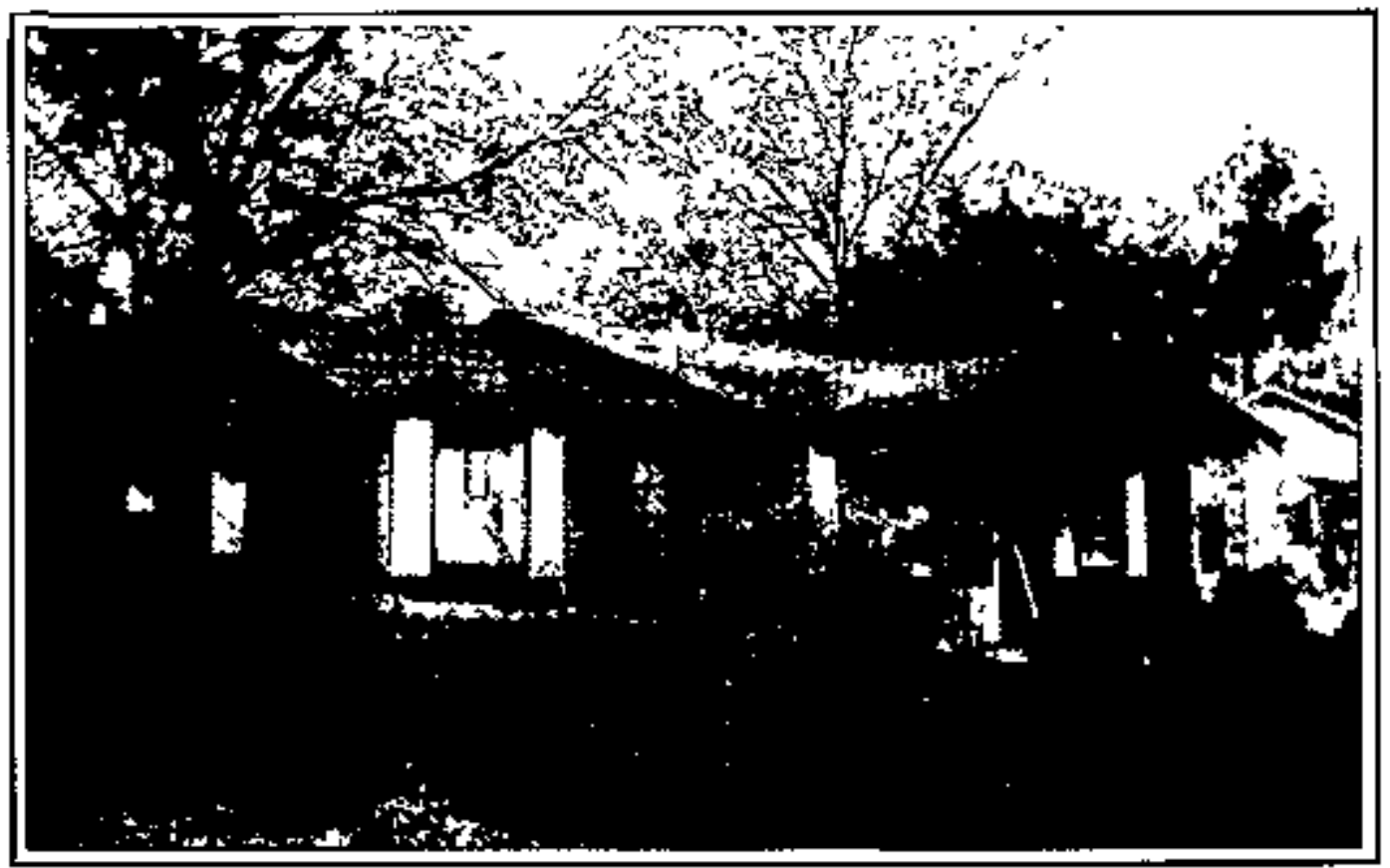

The care of this wood-ftamed home was built in approximately 1955; since then, two small additions have been constructed, resulting in 1,277 square feet of living space, and a complicated roof-line prone to water and air leakage. Prior to weatherization, the home had no insulation in its attic, walls, or foundation, and its 14 wooden window frames and two wooden doors were rotten and leaky. The home was heated by two gas space heaters-one in the living room and the other in one of the four bedrooms. The 30gallon water heater and the stove also used natoral gas.

The weatherization agency spent $\$ 900$ in materials and $\$ 400$ in labor to weatherize this house. A state-wide priority list of measures was used to select the weatherization measures. The job involved blowing approximately 3 " of loose-fill fiberglass insulation across the attic floor, adding two gravity vents for each of the bathrooms, repairing and replacing several windows, replacing one of the doors, and generally caulking and weatherstripping.

During the year after weatherization, the client used $1,002 \mathrm{ccf}$ of natural gas, representing a decrease of $141 \mathrm{ccf}(12.3 \%)$. The occupants judged their home to be noticeably less drafty after weatherization and much less expensive to heat.

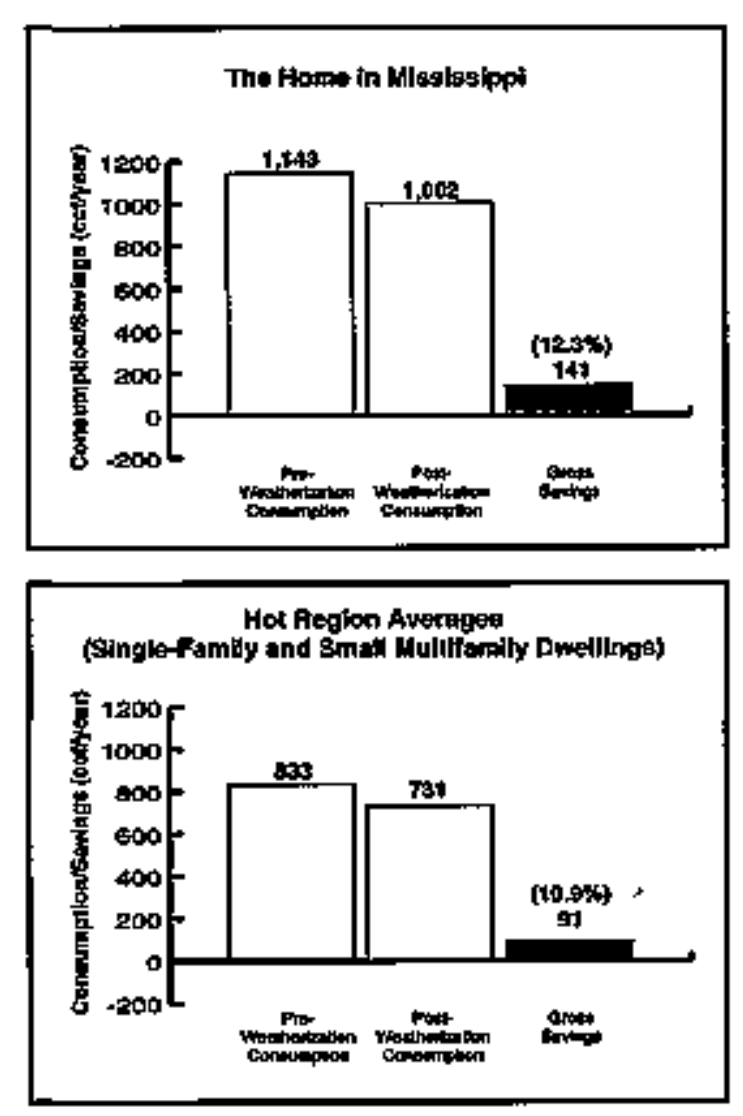




\section{REMAINING OPPORTUNITIES}

\section{A. Additional Investments Per Home}

In general, the amount invested in weatherizing a home is directly related to the magnitude of entergy savings. A regression analysis of over 1,800 gas-heated homes showed that gas energy savings increased by 15 ccflyear with each additional $\$ 100$ invested (in Iabor and materials). The average rate of increase in energy savings did not diminish as investments increased from $\$ 1,000$ to $\$ 3,000$. In PY 1989 , the average investment per house was about $\$ 1,000$ for labor and materials. Houses that received larger investments, however, clearly saved more energy. For example, high-saving dwellings benefited from total expenditures for labor and materials of $\$ 1,192$, which was $14 \%$ more than the national average of $\$ 1,050$. Low-saving dwellings, however, received an investment of only $\$ 714$ (or $68 \%$ ) of the average national investment. Similarly, higher-saying agencies were more likely to obtain funds from non-DOE sources so that a higher average investment per dwelling was possible. These results suggest that there is a cost-effective potential for substantially increasing energy savings by increasing the average investment per dwelling.

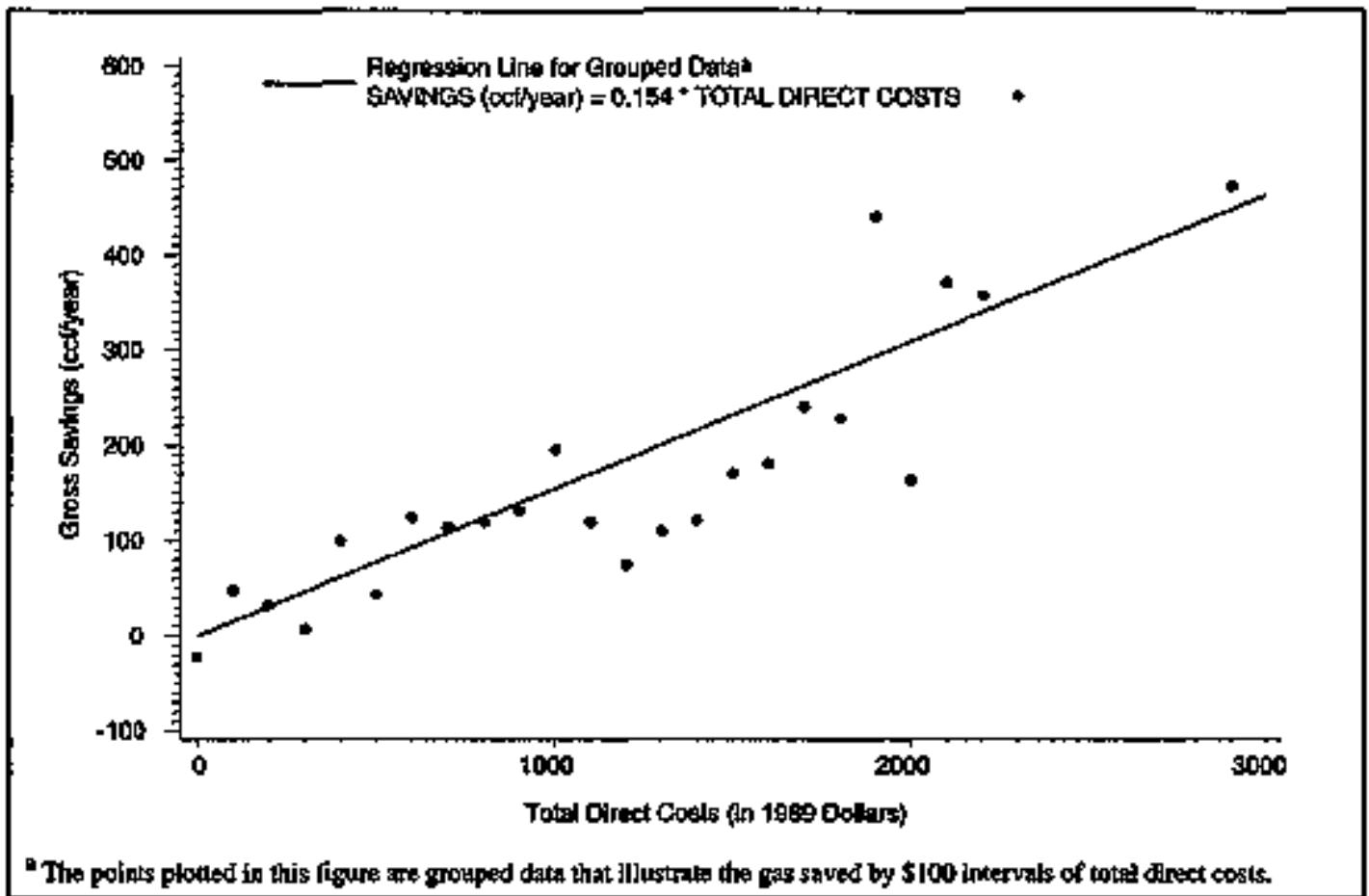

Felationship of Amount Imvested in Weatherlzallon Neasures to Energy Savings

The proportion of the funds invested in various types of weatherization measures also is an important determinant of energy savings. In high-saving dwellings, $38 \%$ of the total spent on materials was invested in insulation, and $16 \%$ in heating systems. In low-saving dwellings, in contrast, $27 \%$ of the total spent on materials was invested in insulation and $3 \%$ in heating systems. In low-saving dwellings far larger proportions were spent on structural repairs (25\% versus $7 \%$ ) than in high-saving dwellings, and more was invested in windows and doors ( $15 \%$ versus $4 \%$ ). Sirnilarly, higher-saving agencies invest more in insulation and heating systems and less in windows and doors. 


\section{TARGETING SAVINGS POTENTIAL}

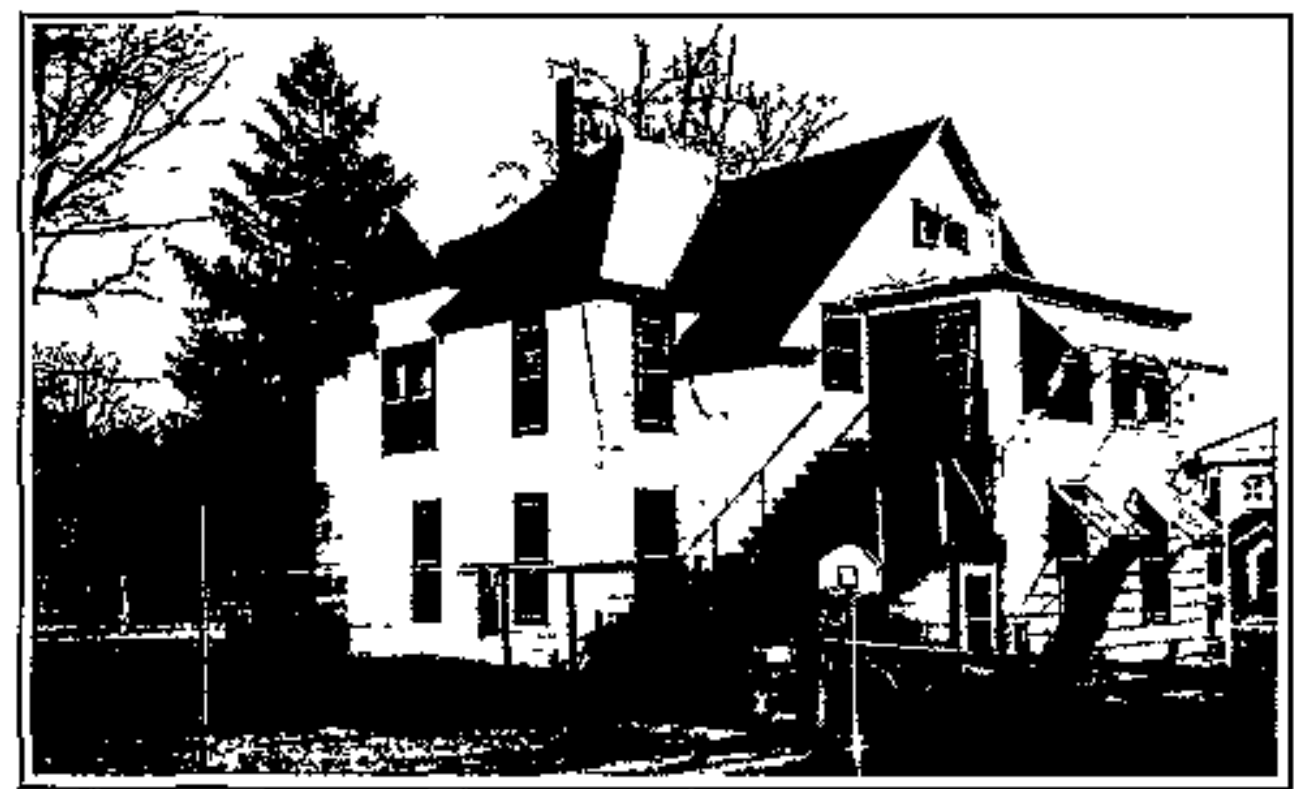

This 90 -year-old home in Nebraska has more than 4,000 \$quare feet of heated living space and 43 windows for tis 10 occupants (eight children and two parents). Although the home had 43 storm windows prior to weatherization, the heating system was inefincient, the attic insulation was insufficient, and no floor or wall insulation was present. Before weatherization, the house consumed 4,800 ccf of gas each year, resulting in annual heating bills of approximately $\$ 2,500$, creating a significant energy burden for this household.

The local weatherization agency spent $\$ 2,250$ in direct materials and labor from a variety of funding sources to weatherize this home. Most of its effort was dedicated to adding insulation to the attic, sidewalls, kneewalls, coilar beams, and floor. In addition, the water heater and water pipes were insulated; air leakages were sealed; the space heating system was cleaned, tuned, and repaired; and several doors and windows were fixed.

These weatherization measures resulted in a $25 \%$ reduction in the househo[d's home heating bills, and created a much mare comfortable living environment. The occupants described their home as "very drafty" prior to weatherization and "not at all drafty" afterwards.
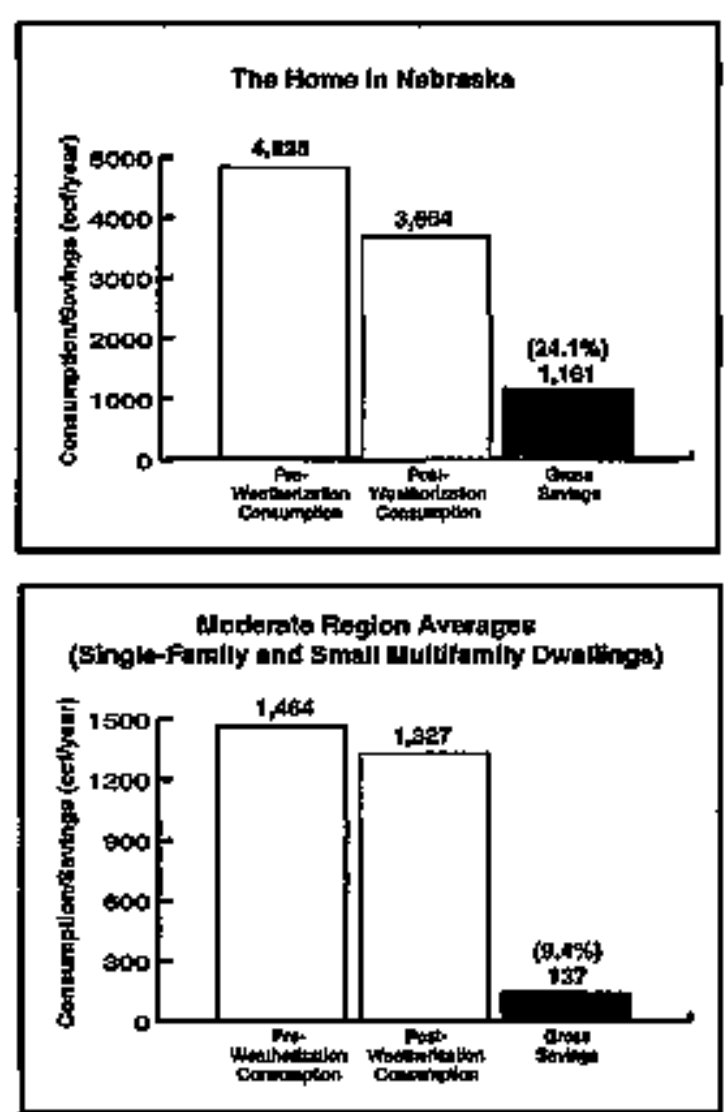


\section{A. Additional Investments Per Home (cont.)}

Many measures installed by the Program show significant opportunities for additional energy-efficiency improvements. Although the weatherized homes were clearly tighter than the control homes, approximately $80 \%$ of them still had air leakage rates that exceeded $1,500 \mathrm{cfm}_{50}$ (a threshold above which more air infiltration reduction is generally recommended). The R-values in weatherized homes were significantly higher than those in control homes, however, the R-values of the attic insulation in weatherized homes were still often below DOE-recommended levejs. For example, about $26 \%$ of weatherized homes had attic R-values of less than R-19 and 63\% had R-values of less than R-30. R-19 or less is below recommended levels in all climate regions in the U.S and R-30 is below the reconnmended level for all except the hottest regions. The need for more frequent instaliations of attic and wall insulation was especially important in the hot region. The poor condition of heating systems and ducts in many homes also pointed to opportunities for additional savings.

AJthough many important, and cost-effective, energy-efficiency inprovements are being implemented by the Program, more funding would make it possible to do much more. Because of the overhead costs involved in setting up work in each bome, it would be most cost effecient to capture as many opportunities as possible during the DOE-sponsored installation. In addition, because a home will rarely be revisited at a later date, cost-effective measures that are not installed are likely to be long-term "lost opporturities." Leveraged funds from utilities, and other sources, are an important vehicle for providing more complete and comprehensive weatherization and for minimizing lost opportunities.

Mary low-income homes need extensive structural repairs, which must be paid for with leveraged funds. For these homes, leveraging of housing rehabilitation funds to supplement DOE funds is an essential step in achieving struchural integrity and energy efficiency.

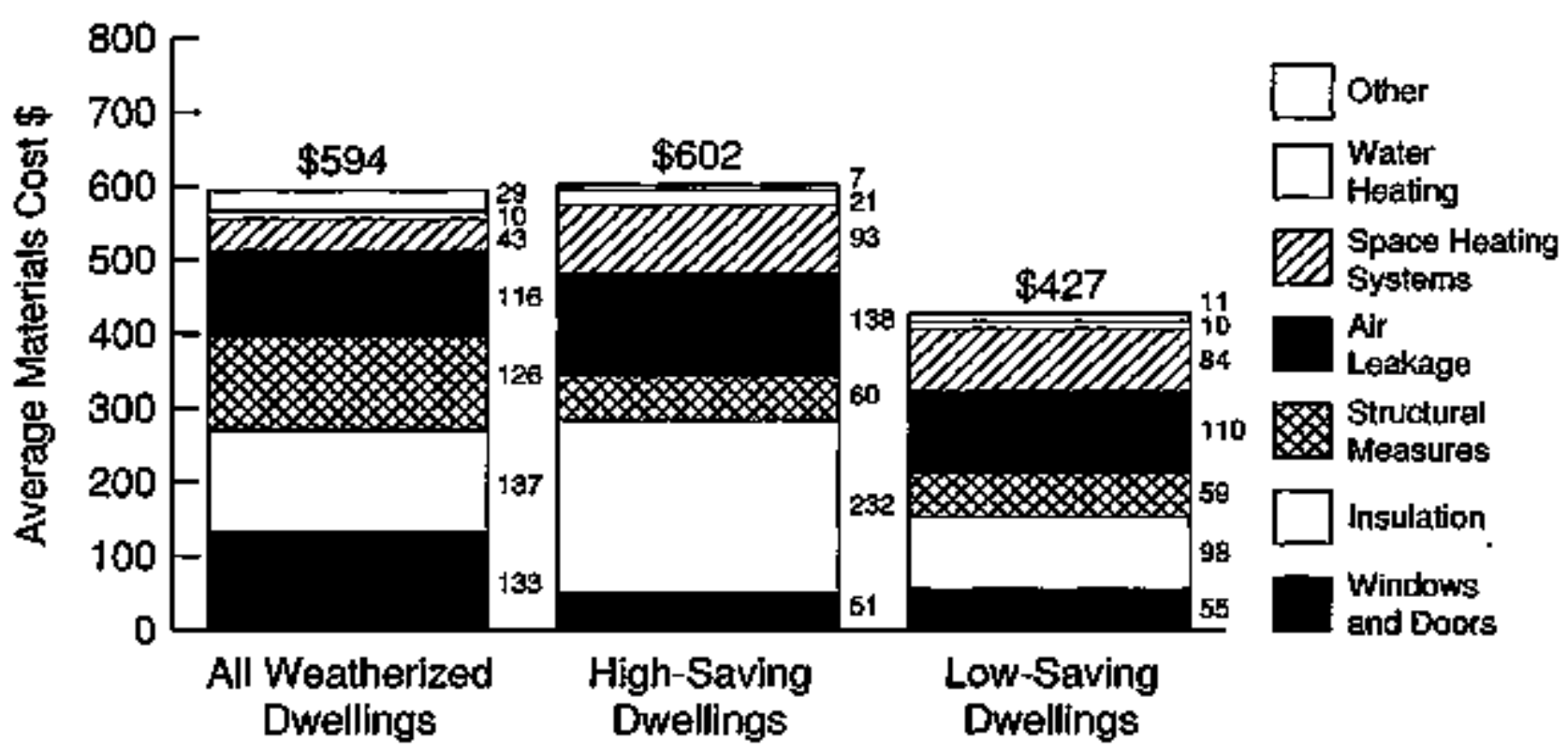




\section{Targeting Needy Households}

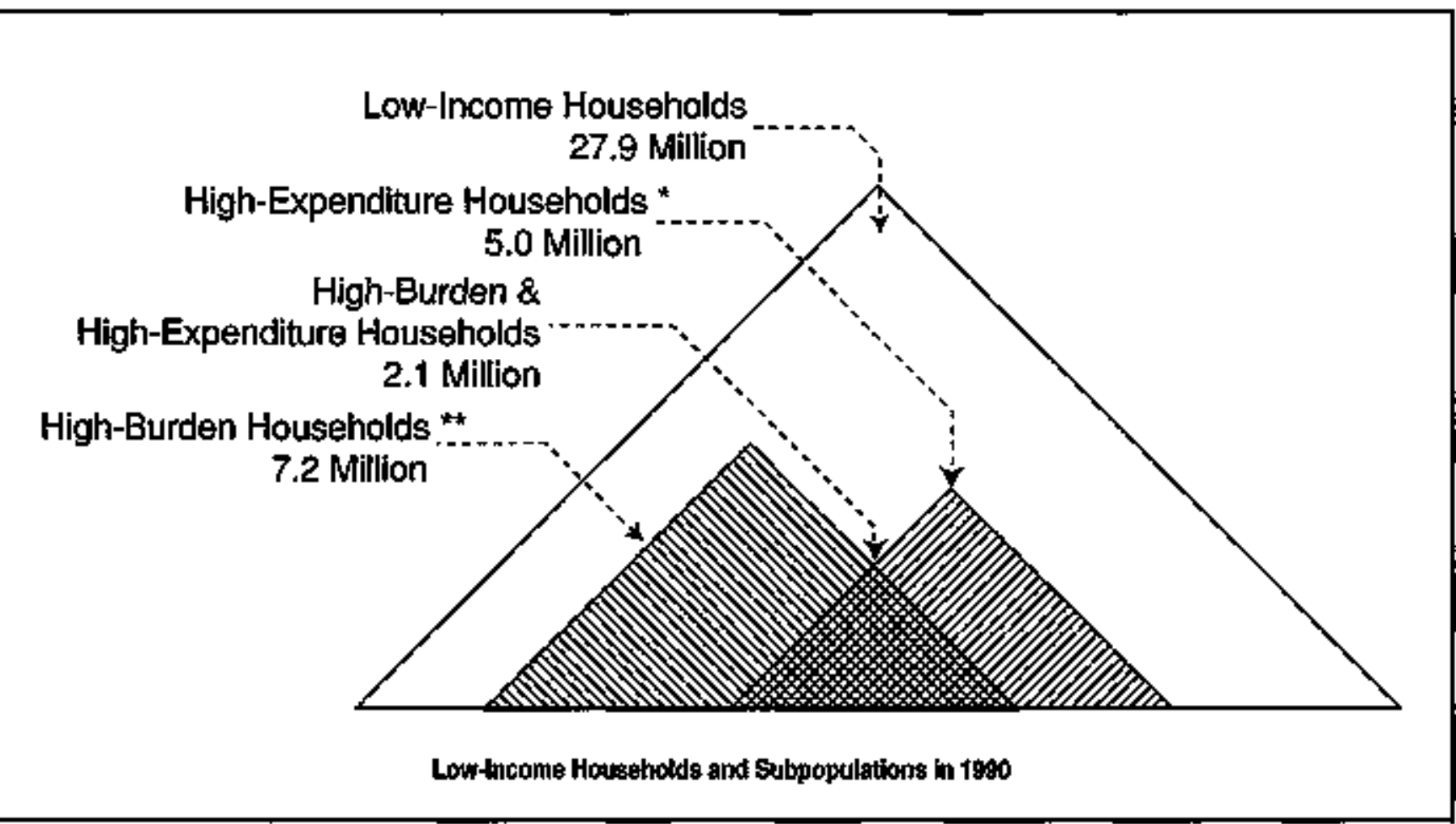

Targeting high burden and high expenditure households offers the opporinnity to reduce utility bills of the neediest households and achieve sizable energy savings. The above diagram identifies 2.1 million program-eligible households that have both high energy expenditures (averaging $\$ 1,339$ per year) and high energy burdens (averaging 30.4 percent of their income). 


\section{B. Targeting the Neediest Households}

According to the Energy Information Administration, in 1990, 19.4 million dwellings were occupied by households with incomes below $125 \%$ of the poverty line (the income eligibility standard used by many states in determining eligibility for the DOE Ptogram) and 27.9 million dwellings were occupied by households with incornes below $150 \%$ of the poverty line (an alternative standard used). Given the large population remaining to be served by the Weatherization Program, it is critical for local agencies to focus resources on households with the greatest need for weatherization and with the largest potential for benefits.

One strategy for targeting weatherization assistance funds is to identify households with both high energy expenditures and high energy burden. High expenditure households are good targets because high expenditures are correlated with high energy savings potential. High burden households are good targets because they can least afford the costs of the energy they consume and they are the least likely to be able to make energy-saving investments in their homes.

The 1990 Residential Energy Consumption Survey (RECS) was used to statistically estimate the size and characteristics of the target group that appears to bave the greatest potential to benefit from weatherization assistance. The evaluation defined the groups as follows:

- High Expenditure Households-those with the highest space heating costs per beating degree day and square foot relative to others in their climate zone and region. This group included 5.0 million low-income households who had average energy expenditures of $\$ 1,233$ and an average energy burden of $19.2 \%$ of inconse.

- High Burden Honseholds - those with the highest energy burden (expenditures in proportion to income) rejative to others in their climate zone and region. This group included 7.2 million low tincome households who had average energy expenditutes of $\$ 1,175$ and an average energy burden of $30.1 \%$ of income.

- High Burden/High Expenditure Flowseholds-those that qualified in both categories above. This group inclnded the 2.1 million households who had average energy expenditures of $\$ 1,339$ and an average energy burden of $30,4 \%$ of income.

Several key characteristics help to define the High Burden/High Expenditure households. These households have very low incomes-lhey have an averageincome of $\$ 6,114$ compared to $\$ 10,048$ for all low-income households. A substantial share of these households represent valnerable population groups-about $40 \%$ are elderly houstholds and another $24 \%$ are single-parent bouseholds. In other ways, fowever, they are much like other low income households - they occupy the same types of dwellings and they use the same types of fuels. Thus, in order to target these households, local agencies need to be particularly attumed to their client's expenditure and burden levels. 


\section{PUTTING IT ALL TOGETHER}

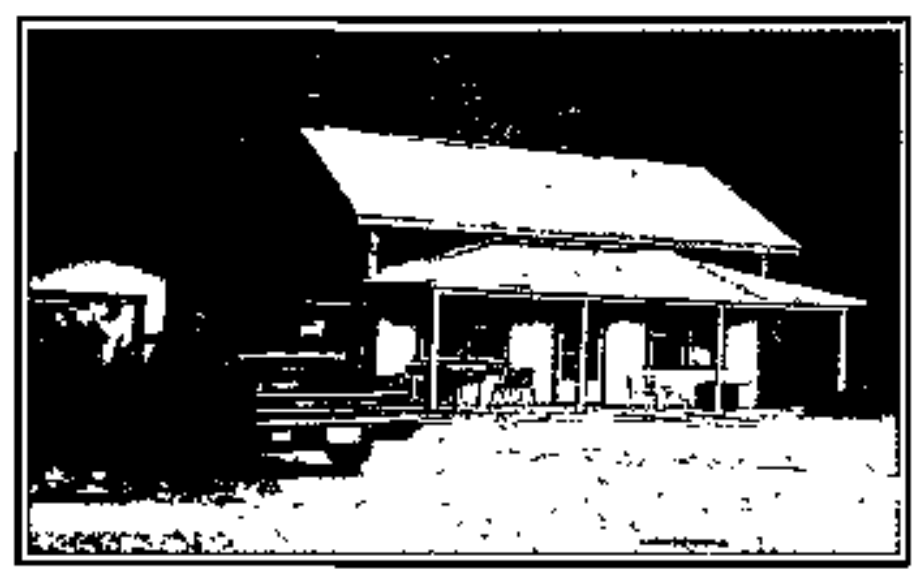

This home in nural New England had a weatherization job that reduced energy costs by more than 50 percent. After the knee wall on the second floor was accessed with a saw from the outside, extensive air sealing and insulation work wete performed. (The access hole is now covered with a rectangular vent.) This weatherization job also inciuded extensive repair of a leaky distribution systern and other infiltration-stoppingmeasures, including a new basement door. Although exterior aesthetics were not altered, the clients were overjoyed with a much more confortable house-and a $\$ 600$ per year saving on their oil bill.
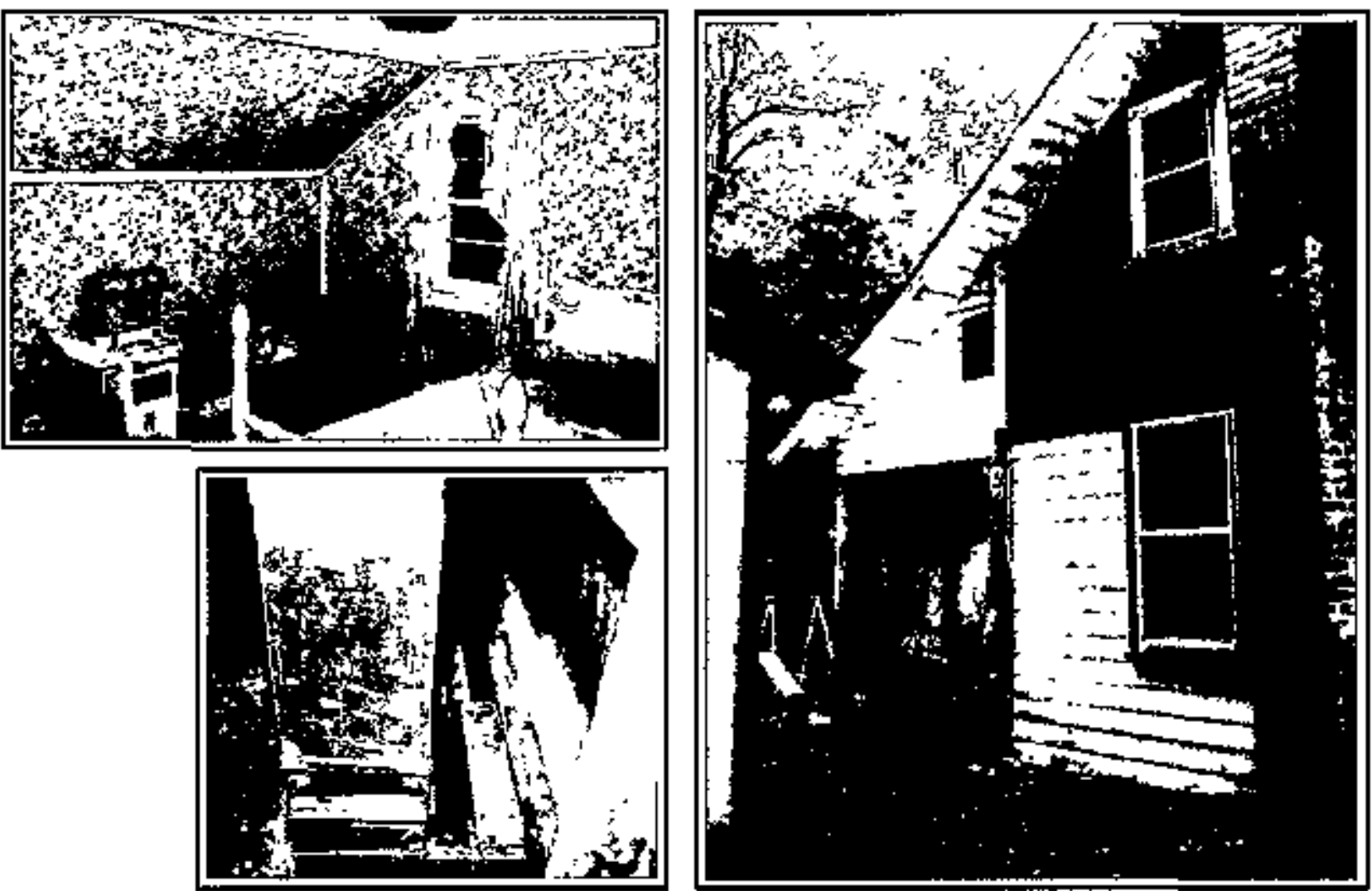


\section{THE FUTURE OF WEATHERIZATION: THE NEXT STEPS}

The various reports produced to date by the National Weatherization Evaluation present a comprehensive profile of weatherization procedures and measures that characterize high-performing agencies and high-saving dwellings. The following recommendations result from these interim findings and describe a series of next steps to enthance the Weatherization Program beyond its already strong foundation.

\section{A. Service Delivery Procedures}

- Enhance the existing high quality of the weatherization work force through increased training and professional development. High-performing agencies are characterized by experienced and well-trained employees. Inproving the ability of the weatherization wotk force to employ diagnostic reasoning and principles from building science will result in even more costeffective weatherization.

- Encourage agencies to direct their resources towards clients that have higher-than-average levels of energy burden. This can be done either through the selection of clients that have a higher-than-average energy burden or the defermination of investment levels based on the preweatherization energy burden. Both the Single-Family and the Fuel-Oil Studies found that energy savings are greatest in dwellings that consume large amounts of energy prior to westherization. These same households aiso tend to spend a high proportion of their incorne on energy. By matching levels of investment with potential for savings, overall program cost-effectiveness will improve.

- Encourage the efforts of states to mobilize other nesources to address the rehabilitation needs of low-income housing. This will enable DOE resources to be focused more on energy-efficiency improvements. Most highperforming agencies have access to non-DOE funds to help pay for housing repairs. The Program will be stronger as more local agencies have access to non-DOE funds for housing rehabilitation while using DOE funds to improve energy efficiency.

- Establish technology transfer mechanisms to promote replication of the success of high-performing agencies. One striking finding of the SingleFamily Sudy is the tremendous diversity among Iocal agencies. A challenge to DOE's Weatherization Program is to heip bring the less innovative and less advanced agencies up to the level of the high-performing agencies in their region. 


\section{KEYS TO SUCCESS}

Case studies of ten high-performing local agencies demonstrate that there are many different formulas for the successful operation of a weatherization progran. Each of the ten agencies employs a unique combination of useful and innovative approaches. At the same time, common features do exist. The following table summarizes the most nofable characteristics that distinguish the ten high-performing agencies from other agencies. These noteworthy features tange from agency and staff characteristics to client recruitment and selection practices; weatherization measures; resource leveraging; and cost controls.

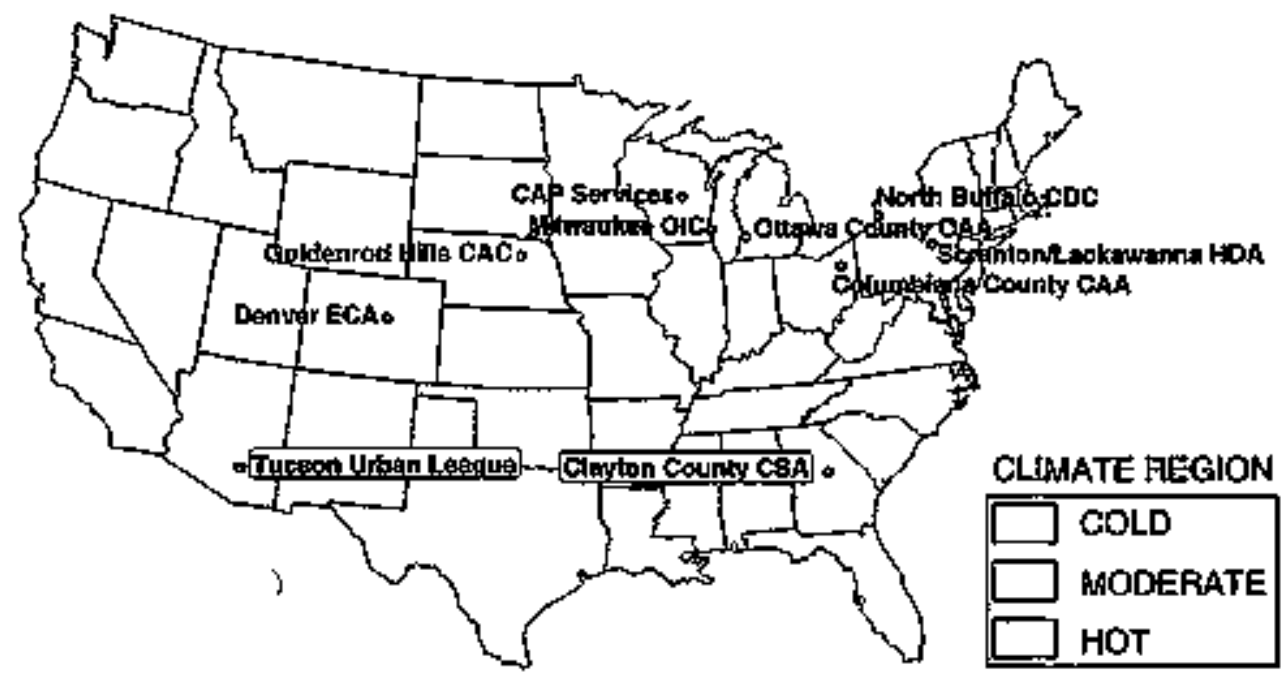

\begin{tabular}{|c|c|}
\hline Category & Characteristic of a Majority of the High Performers \\
\hline Agency Characteristics & Large, mulli-program community action agencles \\
\hline $\begin{array}{l}\text { Characteristics of } \\
\text { Weatherked Housing }\end{array}$ & $\begin{array}{l}\text { High levels of pre-weatherization energy use; older dwellings; } \\
\text { more elderty, oocupants; fewer moble homes; } \\
\text { more central hesting; fewer supplemental heating fuels }\end{array}$ \\
\hline Weatherization Staff & Linited turnower and substantiat wreatherization experience \\
\hline Delivery Systern & In-house craws supplemented by contractors for furmace work \\
\hline Cliant Racrutiment: & Rellance on LIHEAP rosters for recruiling appicants \\
\hline $\begin{array}{l}\text { Selection of Chents and } \\
\text { investment Levals }\end{array}$ & Strong and increasting focus on high energy users \\
\hline Elower Door Use & $\begin{array}{l}\text { Limited use in 1989, extensive use in } 1992 \text { _ during the audit, } \\
\text { while air sealing, and as part of the final inspection }\end{array}$ \\
\hline Weatherization Measures & $\begin{array}{l}\text { Mors first-time attic insulation and we:l insutation; fumace retroflts } \\
\text { and replacements; and water-heater measules }\end{array}$ \\
\hline Leveraging Home Repaits & Access io hotusing rehabilitation funds from non-DOE sources \\
\hline Cost Controls & $\begin{array}{l}\text { Effecliwe cosi controls sugh as bulk purchasing \& in-house } \\
\text { fibrifation of measures }\end{array}$ \\
\hline
\end{tabular}




\section{B. Weatherization Measures}

- Continue the Program's strong emphasis on attic, wall, and floor insulation. High savings in both the Single-Family and Fuel-Oil Studies are associated with greater-than-average levels of investment in insulation. Highdensity wall insulation techniques that can achieve air sealing and insulation in the same operation appear to be especially effective.

- Farther analyze the role of replacement windows and storm windows. The Single-Family and Fuel-Oil Sudies have shown that large investments in windows are especially characteristic of dwellings and agencies that achieve lower-than-average energy savings. Yet at least one high-performing agency specializes in storm windows. Further, owner investments int the weatherization of large multifanily buldings tend to target storm windows. Additional research is needed to assess the conditions under which storm and replacement windows are a cost-effective Program expenditure.

-Increase the emphasis on replacinginefifcientspace-heating systems. High-performing agencies identified in the Single-Family Sudy replace more space-heating systems than other agencies. In addition, they make greater use of instrumented analyses of furnaces and boilers to select measures that promote health, safety, and energy efficiency. System replacements and instrumented analyses are characteristic of high-saving homes in both the Single-Family and Fuel-OI Studies.

- Increase atfention to heating system distribution systems. Dwellings that received duct leakage control measures and distribution system diagnostics achieved above-average savings in the Single-Family Stady.

- Increase attention to water-heating measures. Water-heating conservation measures are characteristic of high-saving homes in the Single-Family and Fuel-Oil \$tudies. Measures to consider should include domestic hot water tank and pipe insulation, water temperanure reduction, low-flow shower heads, and aerators.

- Select measures based on savings-to-investment ratios produced by audits. The Program should discourage the use of prescriptive methods such as statewide priotity lists for the selection of messures. Audits that rank measures by savings-to-investment ratios, calculated for each individual house, produce morecost-effective weatherization. Evidence supporting this reconnmendation was produced by analysis of high-perfoming agencies in the Single-Family Study. 


\begin{tabular}{|c|c|}
\hline \multicolumn{2}{|c|}{ Significant findings of the National Weatherization Evaluation } \\
\hline Finding & $\begin{array}{l}\text { Program-wide } \\
\text { valoe }\end{array}$ \\
\hline First-year energy savings per dwelling (in millions of Buss) & $\begin{array}{l}16.4 \text { (site) } \\
17.6 \text { (source) }\end{array}$ \\
\hline Energy savings as a percentage of energy used for space beating & $18.2 \%$ \\
\hline Energy savings as a percentage of total energy use & $13.5 \%$ \\
\hline First-year dollars saved per dwelling & $\$ 116$ \\
\hline Installation-related costs per dwelling & $\$ 1,050$ \\
\hline Program managernent and instaillation-related costs per dwelling & $\$ 500$ \\
\hline Total weatherization casts per dwelling & $\$ 1.550$ \\
\hline "Program" benefit/cost ratio* & 1.09 \\
\hline "Installation" bereñit/cost"** & 1.61 \\
\hline "Societal" benefit $/ c 0 s t$ ratio*** & 1.72 \\
\hline Cost per million Btus of conserved natural gas & $\$ 4.60$ \\
\hline Cost per $k$ Wh of conserved electricity & $\$ 0.04$ \\
\hline \multicolumn{2}{|c|}{$\begin{array}{l}\text { * Based on energy-savings benefits and total weatherization costs. } \\
\text { ** Based on energy-savings benefits and total installation-related costs. } \\
\text { *** Based on energy-savings, employment, and other nonenergy benefits and total } \\
\text { weatherization costs. }\end{array}$} \\
\hline
\end{tabular}




\section{CONCLUSIONS}

Weatherization is a sound public program that has advanced technically in spite of modest funding over the past decade. It has concrete positive consequences for trousing, neighborhoods, jobs, the environment, the payment of utility bills-and the economic well-being, health, and safety of the low-income peopie it serves. The Program is likely to become even more costreffective as agencles adopt more of the procedures and measures associated with higher energy savings and as new technologies emerge. The trend toward adopting tactics for effectively diagnosing where weatherization measures should be employed-and then installing the right measures for the circumstance-is very important and needs to be accelerated through thoughtful mechanisms of tecinology transfer.

The table on page 56 summarizes the findings of the evaluation of the Weatherization Assistance Program. 


\section{NOTES}

1 The typical dwelling that participated in DOE's Weatherization Program in 1989 is defined as a single-family detached dwelling, located in the moderate region, that heats primarily with natural gas. The Single-Family Study has energy savings estimates for 580 hones that meet this definition. These provide the basis for the profile of the typical dwelling.

${ }^{2}$ The typical agency is defined to be a Iocal weatherization agency located in the moderate climate region that weatherized between 100 and 400 homes in 1989 , most of which were gas-heated single-family detached homes.

${ }^{3} \mathrm{~A}$ barrel of oil is equal to $42 \mathrm{U}$.S. gallons and represented approximately two weeks of petroletm cansumption per American in 1990. 'The "equivalent number of barrel(s) of oil" is, of course, a concrete way of expressing the 3,370 biltion British thermal units (Btus) saved during 1990 due to weatherization work on single-farnily dwellings during Program Year 1989. In reality, of course, the savings occurred not only in gallons of oil, but also in hundreds of cubic feet (cef) of natural gas, kilowatt-hours ( $\mathrm{kWh}$ ) of electricity, and other units of fuel. Where electricity is concerned, savings reported include the energy required to generate electricity at its source.

4Both of these constraints were altered by DOE rulemaking, the final version of which was published in the Federal Register of March 4, 1993. 


\section{REFERENCES}

This summary is subsiantially based on the following reports:

Berry, Linda G., and Marilyn A. Brown. 1994. Patterns of Impact in the Weatherlzation Assistance Program: A Closer Look, ORNL/CON-331, Oak Ridge National Laboratory, Oak Ridge, Tenn.

Brown, Marilyn A., Mark A. Beyer, Joel Eisenberg, Edward J. Lapsa, and Meg Power. 1994. Utility Investments in Low-Income Energy-Efficiency Programs, ORNZ/CON-379, Oak Ridge National Laboratory, Oak Ridge, Tent.

Brown, Marilyn A., Linda G. Berry, Richard A. Balzer, and Ellen Faby, 1993. National lmpacts of the Weatherization Assistance Progran in SingleFamily and Small Multifamily Dwellings, ORNL/CON-326, Oak Ridge National Laboratory, Oak Ridge, Tenn.

Brown, Marilyn A, Linda G. Berry, Laurence F. Kinney, James O. Kolb, Thomas C. Wilson, andDermis L. White. 1993. Keys To Success: Ten Case Studies of Effective Weatherization Programs, ORNLCON-328, Oak Ridge National Laboratory, Oak Ridge, Tenn.

Brown, Marilyn A., and Lawrence J. Hill. 1994. Low-Income DSM Programs: Methodological Approach to Determining the Cost-Effectiveness of Coordinated Partnerships, ORNL/CON-375, Oak Ridge National Laboratory, Oak Ridge, Tenn.

Eisenberg, Joel F., Eugene Michels, David Carroll, and Nancy Berdux, 1994. The Scope of the Weatherization Assistance Program: Profite of the Population in Need, ORNL/SUB/92-SK904/V2, Oak Ridge National Laboratory, Oak Ridge, Tenn.

Kinney, LaurenceF., Thomas C. Wilson, Glenn Lewis, Marilyn A. Brown, and J. Michael MacDonaid. 1994. Case Studies of Weatherization in Large Multifamily buitdings, ORNL/CON-396, OakRidgeNational Laboratory, Oak Ridge, Tenn., Draft

MacDonald, J. Michael. 1993. Description of the Weatherization Assistance Program in Larger Mutifamily Buildings for Program Year 1989, ORNL CON-329, Oak Ridge National Laboratory, Oak Ridge, Tetu.

Mihlmester, Phillip E., Wallace C. Koebler, Jr., Mark A. Beyer, Marilyn A. Brown, and Darrell A. Beschen, Jr., 1992. Characterization of the Weatherization Assistance Program Network, ORNLCON-324, Oak Ridge National Laboratory, Oak Ridge, Tenr.

Power, Meg, JoelF. Eisenberg, Eugene Michels, Marjorie J. Witherspoon, and Marilyn A. Brown. 1993. Scope of the Weatherization Assistance Program: The Weatherized Population and the Resource Base, ORNL/CON325, Oak Ridge National Laboratory, Oak Ridge, Tenn.

Ternes, Mark P., and William P. Levins. 1993. Impacts of the Weatherization Assistance Program in Fuel-On Heated Houses, ORNL/CON-327, Oak Ridge National Laboratory, Oak Ridge, Tenn. 


\section{ACKNOWLEDGMENTS}

For additional help in preparing this report, special thanks to Richard A. Balzer, Fred P. Baldwin, Edward Lapsa, Meg Power, Jeanne Van Vlandren, Bill Wilburn, and Marjorie Witherspoon. Members of the National Weatherization Evaluation's working groups helped design this study, guide its implementation, and interpret its findings. The authors are grateful for their confributions and would like to acknowledge them individually;

Jeff Ackermann

Colorado Department of

Local Affairs

Don Barnett

Missouri Department of

Natural Resonrces

Mary Ann Bamald

Edjson Electric Institute

Jeff Brown

Energy Division, North

Carolina Department of

Comentrce

Dale Canaing

Salt Lake Coramurity Action

Agency

David Carrol]

Response Analysis

Corparation

Mert Dahn

State of Atizona

Department of Conmerce.

Energy Office

Margaret Fels

Princeton University Center

for Energy and

Environmental Studies

Michael Foley

National Association of

Regolatory Utility

Commissioners

Michael Ganley

National Rurel E[ectric

Cooperative Association

Richard Gecardi

New York State Dept. of State

Division of Economic

Opportunity
Sharon Gîl

U.S. Department of Energy,

Chicago Support Offico

Latry Goldbers

Sequoja Technical Services

Miriam Goldberg

U.S. Department of Energy,

Energy Information

Admintstration

Judy Gregory

Center for Neighborhood

Development

Al Gayant

Public Services Commission

of Wisconstn

Matba Hewett

Center for Energy and the

Urban Envitontment.

Bion Howard

Alliance to Sate Eatry

Lasty Kinney

Synertech Systems

Corporation

Judith Lankau

Orange and Rockland

Utilities

Leton LHow

U.S. Deparment of Heslth

and Human Services

Ron Mrabate

Michiggan Departmeal of

Labor

Buresu of Community

Serrices

Jane Marden

Amtrican Gas Association
Phil Miblmester

Aspen Systems Corporation

John Mitchell

Consolidated Edjison

Company, Inc.

Batry Moline

American Public Powter

Assocfation

Jobn Nelson

Wisconsin Gas Company

Kard Pnazek

Directot, Community Action

Program Services

Mes Power

National Community Action

Foundation

Bill Prindle

Alliance to Saye Energy

Ken Rauseo

The Commonisealth of

Massachusetts

Seffrey Scblegel

Wisconsid Energy

Conservation Corporation

Ken Tohínaka

Vermont Energy Iavestment

Corp.

Wendel Thompson

U.S. Department of Energy

Marjocio J. Witherspoon

National Association of State

Community Services

Programs 


\section{APPENDIX A}

\section{EVALUATION DESIGN OF THE SINGLE-FAMILY STUDY}

The evaluation design fot the Single-Family Study consisted of a treatment group of dweilings weatherized in PY 1989 and a control group of applicants for weatherization services.

\section{Sampling Design}

The sample was restricted to dwellings weatherized entirely, or in part, with DOE funds or with funds from other sources that were used according to DOE weatherization regulations. To make sure that the sample captured the diversity of the national program, the existing local weatherization agencies were grouped by size and region, and 400 of these agencies were randonly selected. The 400 agencies then provided lists of the homes they weatherized in PY 1989 and lists of control homes awaiting weatherization. Using these lists, the researchers selected a sample of 18,748 weatberized dwellings $(13,162$ that heated primarily with gas or electricity, and 5,586 that heated primarily with otter fuels) and 11,795 gasor electrically heated control homes.

The representative aational sample was designed to be large enough to provide estimates of national program energy savings for PY 1989 and estimates of savings for key subgroups that were within 10 percent of the mean at a 90 percent confidence level.

\section{Data Collection}

Local agency directors were asked for specific data for each weatherized dwelling: characteristics of the house and its occupants, the weatherization measures installed, and the costs of labor and materials. Attrition at this stage was only 20 percent, mostly due to eliminating dwellings that had been weatherized outside of the study period.

Fuel-consumption records for one year before and one year after weatherization wers requested from the 926utilities that provided gas and/or electricity to those weatherized and control dwellings that heated primarily with gas or electricity. No effort was made to gather fuel consumption records for dwellings using other fuels such as fuel oil, kerosene, propane, wood, or coal. Despiteextensive follow-up activities, attrition was significant: atilities provided complete data for only 4,796 (or 36 percent) of the 13,162 weatherized dwellings and 3,776 (or 32 percent) of the control dwellings that heated primarily with gas or electricity. Nevertheless, the data were sufficient to generate reliable savings and cost-effectiveness estimates.

The second phase of the Single-Fanily Study built on the first phase. In paricular, findings from phase one of the Single-Family Study were used to identify gas-heated weatherized dwellings and local weatherization agencies with a range of gas energy savings. After agencies were ranked by their average gas energy savings, the next step was to select agencies with higher-than-average gas energy savings, and agencies with lower-thar-average gas energy savings for the phase two sample. The result was a purposive sample chosen to allow for comparisons between higher and lower-saving agencjes and dwellings.

Ten of the higher-saving agencies were the subject of irtensive case stadies. The results of thesecase studies were published as a report (Keys to Success: Ten Case Studies of Effective Weatherization Programs) based upon process evaluations aimed at identifying those weatherization practices that explained the documented success of these ten high performers. 
A second part of phase two involved the collection of extensive on-site data on dwelting characteristics, including measurements of air leakage rates, insulation R-values, and steady-state heating system efficiencies for samples of 477 weatherized homes and 288 control homes drawn from 30 agencies. These 30 agencies included the ten higher-saving agencies previously chosen for the case studies plus 20 agencies with Iower-than-average gas energy savings. The principal objective of this sudy was to characterize the energy-efficiency of dwellings occupied by Program clients and to assess the remaining potential for energy-fficiency improvenents. Another objective was to identify factors that produce high and low savings in local agencies and in individual dwellings. In addition, results from interviews with clients were used to assess nonemergy impacts and to determine how energy-related behaviors affected savings.

\section{Data Analysis}

In determiniag savings due to conservation measures like weatherization, it is not enough to merely compare energy bills for a period before and after measures are installed. Weather and many other factors affectconsurnption. For this evaluation, energy savings werecalculated using the Pinceton \$corekeeping Method (PRISM), a sophisticated and widely used procedure that normalizes energy use over time by adjusting for outside temperature differences. (PRISM is described in the Special Scorekeeping Issue of Energy and Buildings, ed. M. Fels, Vol. 9, nos. 1 and 2, 1986.) The process is analogous to a procedure to nernatize for highway and city driving in a miles-per-gallon analysis of automobile fuel consumption.

After normalizing for weather, gross savings wero calculated as the difference between energy use before and after weatherization. Finally, consumption of a large group of control homes was analyzed over the same periods. This enabled small (but accurate) adjustments to be made to account for changes in energy use that would have occurred in the absence of weatherization. Net savings of weatherized dwellings were computed by subtracting the average gross savings for control homes from the average gross savings for weatherized homes.

This analysis of stavings was performed on all houses for which fuel consumption data were available, including those whose occupants changed during the course of the data collection period. Alaska and Hawaii were excluded from the National Weatherization Evaluation because the necessary field work would have been prohibitively expensive. 


\section{EVALUATION DESIGN OF THE FUEL-OIL STUDY}

This study was limited to single-family houses that heated primarily with fuel oil and are located in nine states in the Northeast. The evaluation destign for the Fuel-Oil Sudy consisted of asplit-winter design involving two heating seasons (1990-91 and 1991-92). Weatherized homes received energy conservation measures in January of each heating season. The three months before and after weatherization comprised the pre- and post-weatherization data collection periods. This split-winter design reduced costs by allowing re-use of the instrumentation for a second year.

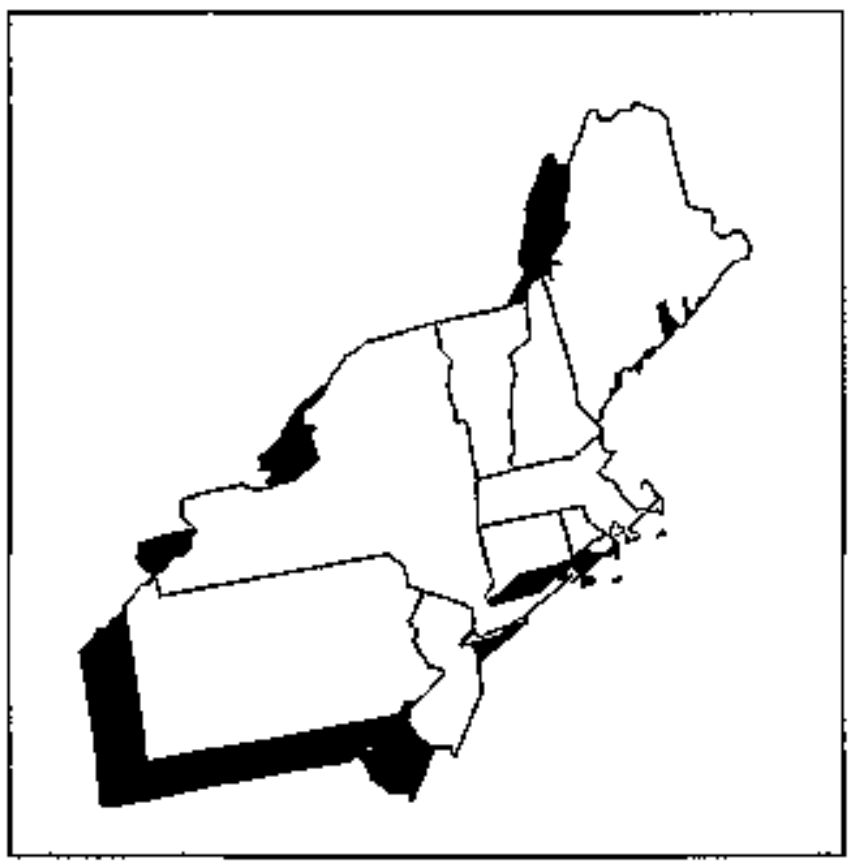

The Nine States Included in the Puel-Oil Study.

\section{Sampling Design}

At least two agencies were chosen from each of the nine northeastem stafes during 1990-91 and at least one agency from each state during 1991-92 to ensure a representative sample. Selection of agencies within states and test houses within agencies was random. In the 1990-91 heating season, 121 weatherized and 70 control homes, drawn from 25 agencies, were monitored. In the 1991-92 heating season, the remaining 101 weatherized and 45 control homes, drawn from a different set of 16 agencies, were monitored.

\section{Data Collection}

A data-logger in each house recorded inside and outside temperatures and heating system run-time data, and sent averaged hourly data each week via a modem to a

central computer. Information about the physical characteristics of each house and its space-heating system was collected at the end of the post-weatherization period. A comprehensive questionnaire was used to obtain occupant characteristics and their perceptions of Progrann impacts. Local weatherization agencies provided information for each house on service delivery procedures, weatherization dates, installed measures and costs, and household income.

Blower-door tests were performed before and after wetherization to determine changes caused by weatherization measures. Steady-state efficiencies of space-heating systems were measured in each house for both pre- and postweatherization periods. Safety inspections of space- and water-heating systems were perfomed at the end of the postweatherization period in all weatherized houses. Control houses were similarly tested. 
